C1998 Intermational Monetary Fund

April 1998

IMF Staff Country Report No. 98/28

\title{
Israel: Background Studies, Information Notes, and Statistical Appendix
}

This Background Studies, Information Notes, and Statistical Appendix report on Israel was prepared by a staff team of the International Monetary Fund as background documentation for the periodic consultation with this member country. As such, the views expressed in this document are those of the staff team and do not necessarily reflect the views of the Government of Israel or the Executive Board of the IMF.

Copies of this report are available to the public from

International Monetary Fund - Publication Services

700 19th Street, N.W. • Washington, D.C. 20431

Telephone: (202) 623-7430 - Telefax: (202) 623-7201

Telex (RCA): 248331 IMF UR

Internet: publications@imf.org

Price: $\$ 15.00$ a copy

International Monetary Fund

Washington, D.C. 



\section{INTERNATIONAL MONETARY FUND}

\section{ISRAEL}

Background Studies, Information Notes, and Statistical Appendix

Prepared by a staff team consisting of David W.H. Orsmond and Ling Hui Tan (both EU1)

Approved by the European I Department

January 23, 1998

Contents

Page

Background Studies

I. Estimates of Potential Output in Israel

II. Tax Revenue Shortfalls in 1995-97 16

III. Volatility of Interest Rates in Israel 29

Information Notes

I. Summary of the Tax System and Tax Incentives as of January 1, 1997

II. Recent Developments in the Exchange and Trade System 56

Statistical Appendix Tables

A1. GDP by Expenditure Components in Current Prices, 1992-97 58

A2. GDP by Expenditure Components in Constant Prices, 1992-97 59

A3. Investment, 1992-96 60

A4. Consumption, 1992-96 61

A5. Gross Private Income and Savings, 1992-96 62

A6. National Saving, Foreign Savings, and Investment, 1992-96 63

A7. Industrial Production Indices, 1992-97 64

A8. Labor Market Indicators, 1992-97 65

A9. Employment and Labor Input by Industry, 1992-96 66

A10. Real Wages, Labor Costs, and Productivity, 1992-96 67

A11. Real Wage Indices, 1992-97 68 
A12. Consumer Price Index and its. Main Components, 1992-97 69

A13. Selected Price Indices, 1992-1997 70

A14. Regulated Prices in the Consumer Price Index (as of August 1997) 71

A15. Bank of Israel Accounts, 1992-97 72

A16. Monetary Survey, 1992-97 73

A17. Financial Assets of the Public, 1992-97 74

A18. Commercial Bank Credit to the Private Sector, 1992-97 75

A19. Interest Rates, 1992-97 76

A20. Interest Rates on Various Types of Credit and the Public's Assets, 1992-97 77

A21. Reserve Requirements on Deposits and Interest Brackets, 1992-97 78

A22. Sources of Changes to the M3 Base, 1992-97 79

A23. Factors Affecting the M3 Base, 1992-97 80

A24. The Israeli Capital Market, $1996 \quad 81$

A25. Principal Stock Market Indicators, 1992-96 82

A26. Principal Bond Market Indicators, 1992-96 83

A27. Institutional Investor Indicators, 1992-96 84

A28. State Budget Balance and Financing, 1992-98 85

A29. State Budget Revenue, 1992-98 86

A30. State Budget Expenditure (Economic Classification), 1992-98 87

A31. State Budget Expenditure (Functional Classification), 1992-98 88

A32. General Government Balance and Financing (National Accounts), 1992-96 89

A33. General Government Receipts (National Accounts), 1992-96 90

A34. General Government Expenditure (National Accounts), 1992-96 91

A35. Structure of General Government Finances (National Accounts), 1992-96 92

A36. The Largest Government Companies (as of December 31, 1996) 93

A37. Privatization and Raising of Capital from the Public by Issuance of

Shares and Convertible Securities (1995 to September 15, 1997) 94

A38. Privatization of Banks and Raising of Capital from the Public by

Issuance of Shares and Convertible Securities, 1991-97 95

A39. Currency Basket of the Israeli Sheqel, 1992-97 96

A40. Exchange Rate Developments, 1992-97 97

A41. Overall Balance of Payments, 1992-97 98

A42. Balance of Payments-Services, 1992-97 99

A43. Export Volume and Price Indices, 1992-97 100

A44. Commodity Composition of Exports, 1992-97 101

A45. Destination of Exports, 1992-97 102

A46. Civilian Import Volume and Price Indices, 1992-97 103

A47. Commodity Composition of Civilian Imports (c.i.f.), 1992-97 104

A48. Origin of Imports, 1992-97 105

A49. Capital Account Transactions, 1992-97 106

A50. Indicators of External Indebtedness, 1992-97 107

A51. Indicators of Debt Service, 1992-97 108

A52. Assets and Liabilities in Foreign Currency, 1992-97 109

A53. Official Gold and Convertible Foreign Exchange Reserves, 1992-97 110 


\section{Estimates of Potential OUTPUT IN ISRaEL ${ }^{1}$}

1. The Israeli economy has changed dramatically over the past decade. The 1985 stabilization program-which saw inflation fall from 185 percent to close to 20 percent within a year-was followed shortly thereafter by a massive wave of immigration that increased the population by almost 20 percent. Though initially pushing the unemployment rate up from $61 / 2$ percent to over 11 percent, the new skilled labor force was rapidly absorbed. In consequence, the unemployment rate fell back as output expanded on the order of 40 percent over six years, led by an export-oriented investment boom aimed at taking advantage of the increased human capital. More recently, in part due to the decline in immigrant intakes, output growth in Israel has slowed.

2. These rapidly changing developments pose a challenge for efforts to measure potential output. ${ }^{2}$ Four methodologies are employed in this study, two fairly traditional approaches and two approaches using relatively new statistical techniques. Traditional approaches to measure potential output typically rely on estimation of a production function or use of the HodrickPrescott filter to smooth actual output. But in the case of Israel these approaches may lead to misleading results, since both techniques assume the existence of relatively stable conditions over an extended period of time. In contrast, two recent statistical approaches yield measures of potential output that are designed to adapt to changes in economic circumstances. First, a smoothing filter based on the "wavelet" approach adapts the estimate of potential output to changes in the economic environment so that recent events such as immigration influence the estimates of potential output at the end of the sample period (and not at the beginning). Second, a structural vector autoregression (VAR) exploits the relationship between output growth and inflation to distinguish between permanent changes in potential output and transitory fluctuations in actual output above or below this level. ${ }^{3}$

\section{A. Theoretical Approaches to the Concept of Potential Output}

3. Even abstracting from estimation difficulties, the concept of "potential output" is not well defined. Broadly speaking, the literature distinguishes between two definitions. In the first, more along the Keynesian tradition, the business cycle results primarily from movements in aggregate demand in relation to a slowly moving level of aggregate supply. In business downswings, there exist factors of production that are not fully employed; most critically, unemployment remains above its frictional level, and wage and inflation pressures are subdued. In this framework, potential output is formalized based on the concept of the

\footnotetext{
${ }^{1}$ Prepared by Fabio Scacciavillani, Phillip Swagel and David W.H. Orsmond.

${ }^{2}$ De Masi (1997) surveys methodologies traditionally used to estimate potential output.

${ }^{3}$ A similar methodology is used by De Serrers, Guay, and St-Amant (1995) and Dupasquier and Guay (1997) for Mexico and Canada, respectively.
} 
nonaccelerating inflation rate of unemployment (NAIRU), where the gap between actual and potential output indicates the extent to which the economy can expand without inflation accelerating.

4. In contrast to the first approach, potential output in the second approach-more along the (neo) classical tradition-is driven by exogenous "productivity shocks" to aggregate supply that determine its long run growth trend and to a large extent the short term fluctuations of the business cycle. Under such a framework, business cycle fluctuations are not caused by changes in monetary, fiscal, or other policy choices; they are instead unavoidable reactions by rational agents that are responding to unexpected productivity shocks by writing off old investments and regrouping resources in order to re-coordinate production and thereby adapt to the new conditions (Theis, 1991). ${ }^{4}$

5. Given these underlying economic concepts, different methodologies are required to estimate the two notions of potential output. Under the first approach, the appropriate procedure is to estimate an aggregate production function, or more generally a fully specified macroeconomic model that incorporates a production function. Under the second approach, potential output coincides with a "smoothed" measure of actual output, so that the key measurement problem is to distinguish between permanent and transitory movements in actual output. Unlike the first framework where the economy might never reach its potential output level even over an extended period, in the second framework potential output is synonymous with the actual trend growth rate of output.

\section{B. Description of Methodologies to Estimate Potential Output}

6. With these concepts as background, this section describes the various estimation methods used in this study to derive an estimation of potential output.

\section{Estimating the production function}

7. Estimating potential output within the first framework is based on the growth rates of the factors of production-physical capital and labor-plus an estimate of total factor productivity. In particular, the rate of growth of potential output is calculated by the growth rate of physical capital and of the labor supply, weighted by the share of capital and labor in the production function, and then adding the growth rate of total factor productivity. In the context of Israel where the capital to labor ratio has decreased since 1990 as a result of skilled immigrants entering the workforce, a measure of human capital is needed to reconcile the rapid increase in per-capita output with the decline in the stock of physical capital per person. Without such an adjustment, estimates using Cobb-Douglas or even a more flexible translog

\footnotetext{
${ }^{4}$ Under this framework, fluctuations in output can still occur due to changes in distortions introduced by the tax regime, protectionist measures, and labor market rigidities. The policy prescription in this case is to remove the distortion.
} 
functional form for the production function result in capital share parameters of 70 percent or more, despite the actual capital share being around 30 percent.

8. The 1996 Annual Report of the Bank of Israel presents a version of the production function methodology to estimate potential output growth in the business sector in 1996. In particular, it is assumed that the aggregate production function obeys a Cobb-Douglas specification with a capital share in output of 32 percent and labor share of 68 percent, which are the actual capital and labor shares in production in the most recent years (as produced by the Central Bureau of Statistics). Annual productivity growth is assumed to lie between 1.6 percent and 2.6 percent, which are the averages over the last ten years and over a more extended period. For this study, potential output under the production function approach has been estimated by holding constant these parameters over the period 1987-1996; the resulting estimates are described in the next section. While this approach offsets the difficulties noted above when the capital and labor shares are estimated statistically, the assumption that these shares have been constant over time at their most recent levels may also introduce a bias in the estimates.

\section{Using the Hodrick-Prescott filter}

9. While some of the paradigms along the (neo) classical tradition stress that economic fluctuations are generated by technology shocks, the underlying theory does not provide direction on how to distinguish between permanent movements related to growth of potential output and temporary fluctuations due to the business cycle. The Hodrick-Prescott (HP) filter is probably the most widely used method by which to extract a trend from macroeconomic data. Specifically, the HP filter statistically estimates potential output by minimizing the size of the actual output fluctuations around its trend, subject to a constraint on the maximum allowable change in the growth of trend output between two periods. In its standard form, the HP filter computes potential output by removing from actual output all cycles with frequencies less than eight years. ${ }^{5}$

10. The HP filter has several shortcomings, namely the somewhat arbitrary choice of the assumed business cycle frequency, the neglect of structural breaks and regime shifts, the inadequate treatment of nonstationary dynamics, and the consequent filtering out of rapid structural shifts in the economy (such as that which recently occurred with the slowdown in immigration). If the structure of the economy is thought to be reasonably stable and the growth of potential output relatively smooth, then the HP filter will provide a reasonable estimate of potential output. If, however, there are many structural breaks - as has likely been the case in Israel-then the use of the HP filter may be inappropriate since the estimation procedure may remove structural breaks from the underlying data that in fact represent a change in the trend level of potential output.

${ }^{5}$ This choice can be traced back to Burns and Mitchell (1947), who found that the business cycle in the United States varied between two to eight years. 


\section{Using a "wavelet" filter...}

11. The "waveshrink" methodology separates permanent movements in actual output from transitory fluctuations in actual output, and as such offsets some of the difficulties encountered with the use of the HP filter when the shocks experienced by the economy are thought to reflect a rapidly changing economic structure. Specifically, the methodology entails calculating a discrete transform of the actual data, eliminating components that correspond to transitory movements in output, then reconstructing a new series for potential output using only the remaining coefficients. ${ }^{6}$ An advantage of a wavelet filter over the HP filter is that it does not rely on arbitrary assumptions about the regularity of the fluctuations, allowing potential output to evolve within rapidly changing dynamics, rather than simply following a smooth evolutionary path.

\section{Estimating potential output through vector autoregression (VAR) procedures}

12. The final estimate of potential output used in this study combines aspects of the Keynesian and neoclassical traditions, exploiting the statistical relationship between inflation and growth to distinguish between permanent and transitory movements in output. The additional information utilized in such a bivariate analysis can improve on the univariate HP and wavelet filters: for example, faster growth of output without a corresponding increase in the rate of inflation will be taken to imply that the economy is at that time operating below potential, while the emergence of inflation in the face of growth would suggest that the actual output level is at that time above its potential level. The structural VAR with output growth and inflation estimated was similar to that in Blanchard and Quah (1989). ${ }^{7}$ The VAR was identified by imposing the restriction that a "demand" shock has a long run effect on the price level but only transitory effects on the level of output, while a "supply" shock was allowed to have permanent effects on both prices and output. The effects of both supply and demand shocks on prices and output were left unconstrained in the short run. The output gap was defined as the component of the forecast error of output that is attributed to demand-that is, the shortfall or excess of demand over supply that is attributable to "transitory" factors. Potential output then equals the sum of actual output and the output gap.

${ }^{6}$ Donoho and Johnstone (1992) prove that if a wavelets basis exists, it provides the optimal method with which to extract a signal from white noise. Donoho $(1993,1994)$ develops a method, called wavelet de-noising or wavelet shrinkage (hence the term "waveshrink") to extract the unobserved series of potential output, $\mathrm{Y}^{*}$, from a regression-like equation in which the observed data for output equals the sum of potential output and short term stochastic movements in output.

${ }^{7}$ Inflation is used in place of the unemployment rate variable typically used in similar analyses for the United States because the relationship between output and unemployment appears to be unstable in Israel following the immigration. 
13. Since inflation is likely to respond to changes in output growth only with a lag, the variables used in the VAR in this note were the contemporaneous quarterly growth rate of output and the logarithmic change in the price level between the current quarter and four quarters ahead. Moreover, since there are two distinct periods of inflation, with inflation rates between 15 percent to 25 percent until the beginning of 1991 and then between 8 percent and 15 percent afterwards, the inflation series used for the VAR was "de-meaned" or "standardized" by subtracting the average rate of inflation in each of the two periods before and after the second quarter of 1991. The VAR was run with four lags of each variable, since likelihood ratio tests did not reject the null hypothesis that additional lags were not statistically significant. ${ }^{8}$

\section{Results of the Estimations}

14. Table I. 1 summarizes the results when the four methodologies are applied over the period 1987-96, while Figures I.1-I.4 show the (log) trend estimates of potential output against actual output over this period. ${ }^{9}$ The results using the production function methodology suggest potential output was growing at around 4-5 percent in the second half of the 1980s, then accelerated to around 7 percent during the 1990s in response to the pick up in the rate of growth of investment as well as the high levels of immigration and consequent increase in the labor force. Although actual (business sector) output was also high during this period, the increase in aggregate supply was even larger. Assuming there was no output gap in 1988-the year prior to the first immigration wave when unemployment was at its recent nadir of around $61 / 2$ percent-the output gap was negative during most of the subsequent period, indicating that actual output level was below potential. For 1996, potential output of the business sector

${ }^{8}$ Before estimating the VAR, the time series properties of the data for (business sector) output and inflation were examined. Standard statistical tests for stationarity such as the DickeyFuller and Phillips-Perron tests did not reject the null hypothesis of a unit root in the levels of prices and output, but did reject the null hypothesis that a unit root exists in growth rates (the results are not shown here). The Johansen-Juselius trace test for cointegration did not reject the null hypothesis of no cointegrating relationship between prices and output for the poststabilization period, and rejected the null hypothesis of one cointegrating vector. These results indicated the VAR should be run on the first differences of output and the price level (that is, output growth and the rate of inflation), but there was no need to augment the VAR with an error correction mechanism.

${ }^{9}$ The estimate of potential output using a production function was based on annual data since the capital stock estimate is only available at end year dates. Following the Bank of Israel, this methodology was used to estimate potential output of just the business sector. For the other three methodologies, the estimate of potential output was based on seasonally unadjusted quarterly data for real total GDP. The estimation equation for the HP and wavelet filters were based on data for the period 1980-96, though only the estimates for 1987-96 are shown here. 
was estimated to be growing at 6 percent annually, and the output gap stood at close to 2 percent of GDP (Figure I.1).

15. The estimates under the HP filter suggest the growth rate of potential output rose steadily, from 4 percent annually at the end of the 1980 s to $51 / 2$ percent within three years thereafter, and then reached its maximum of 5.8 percent in 1994-95. It fell back marginally in 1996 reflecting the (small) effect on the HP estimate from the somewhat slower actual growth performance in that year. Output fluctuated around this trend-especially the quarterly estimates-though the output gap was generally positive (the actual output level was somewhat above its potential) during the 1990s. However, by 1996, when the rate of growth of potential output was estimated at 5.7 percent, the output gap had been closed (Figure I.2).

16. The estimates under both the wavelet and VAR methodologies show potential output moving much more in line with actual output levels as the estimate "adapts" to changing economic circumstances. Figure I.3 shows actual output along with the (log) level of potential output by applying an " $\mathrm{s} 4$ " wavelet filter. ${ }^{10}$ From a low point of around 2 percent annually at the end of the $1980 \mathrm{~s}$, the (smoothed) estimate of potential output accelerated rapidly in the early 1990s, reaching an annual rate of around 7 percent. Though the quarterly data were rather volatile, the estimated annual output gap remained close to zero during the $1990 \mathrm{~s}$. As suggested from the above, the magnitude of the gap is, in general; substantially smaller than that estimated using the HP filter, since the wavelet filter responds more rapidly to changes in underlying conditions. In 1996, the wavelet methodology suggests potential output was only growing at around 4 percent, but like the HP filter, that there was virtually no gap between actual and potential output at that time.

17. Finally, the VAR methodology shows a similar story to that for the wavelet procedure, as the results show estimated levels of potential output that were very closely in line with the actual quarterly output levels (Figure I.4). Following the acceleration of growth to 6-7 percent in the 1990s, the estimate of potential output fell back to around 5 percent by 1996 , with virtually no gap between actual and potential output at that time.

\footnotetext{
${ }^{10}$ This is one of many varieties of wavelets filters; it was chosen after an extensive selection process because the estimates from the $s 4$ wavelet offer a balance between adaptability and stability. Moreover, statistical tests do not reject the null hypothesis that the residuals are white noise, indicating that the filter appropriately separates permanent movements in potential output from the "noise" of business cycle fluctuations.
} 


\section{Conclusions}

18. All of the four methodologies used in this study indicate that annual potential output accelerated during the 1990s to a level of around 6-7 percent by 1995 . The results are less uniform regarding the recent growth rate of potential output, which was estimated to be growing in 1996 at between 4-6 percent (depending on how sensitive the methodology is to the slowdown in growth that began in 1996). This implies some differences between the four approaches as regards the size of the existing gap in most recent periods. Three methodologies (second, third, and fourth) show that there was virtually no output gap in 1996 for the economy as a whole, while the production function methodology suggests an output gap of some 2 percent for business sector output at that time. 
Table I.1. Estimates of Potential Output Under Varying Methodologies

\begin{tabular}{|c|c|c|c|c|c|c|}
\hline & \multicolumn{2}{|c|}{ Actual $1 \%$} & \multicolumn{4}{|c|}{ Potential Output } \\
\hline & GDP & $\begin{array}{c}\text { Business } \\
\text { Output }\end{array}$ & $\begin{array}{l}\text { Production } \\
\text { Function } 2 /\end{array}$ & HP Filer & $\begin{array}{l}\text { Wavelet } \\
\text { Filter }\end{array}$ & VAR \\
\hline & \multicolumn{6}{|c|}{ (Indices of output; $1988=100$ ) } \\
\hline 1987 & 96.6 & 96.4 & 94.6 & 96.2 & 97.4 & 97.2 \\
\hline 1988 & 100.0 & 100.0 & 100.0 & 100.0 & 100.0 & 100.0 \\
\hline 1989 & 101.2 & 101.0 & 105.1 & 104.1 & 101.7 & 101.4 \\
\hline 1990 & 107.4 & 108.7 & 109.8 & 108.7 & 106.5 & 106.9 \\
\hline 1991 & 114.2 & 116.9 & 118.5 & 114.0 & 114.1 & 114.2 \\
\hline 1992 & 121.6 & 126.5 & 126.5 & 120.2 & 121.2 & 121.1 \\
\hline 1993 & 125.9 & 131.2 & 135.4 & 126.9 & 125.9 & 125.5 \\
\hline 1994 & 134.4 & 141.6 & 145.1 & 134.3 & 134.5 & 134.9 \\
\hline 1995 & 143.9 & 154.2 & 155.8 & 142.1 & 144.4 & 143.5 \\
\hline \multirow[t]{2}{*}{1996} & 150.2 & 161.9 & 165.4 & 150.3 & 149.9 & 150.6 \\
\hline & \multicolumn{6}{|c|}{ (Rates of growth; in percent) } \\
\hline 1987 & 6.3 & 8.5 & 3.8 & $\ldots$ & 6.3 & \\
\hline 1988 & 3.5 & 3.7 & 5.7 & 4.0 & 2.7 & 2.9 \\
\hline 1989 & 1.2 & 1.0 & 5.1 & 4.1 & 1.7 & 1.4 \\
\hline 1990 & 6.1 & 7.6 & 4.5 & 4.4 & 4.7 & 5.5 \\
\hline 1991 & 6.3 & 7.6 & 8.0 & 4.9 & 7.2 & 6.8 \\
\hline 1992 & 6.6 & 8.2 & 6.8 & 5.4 & 6.2 & 6.0 \\
\hline 1993 & 3.5 & 3.7 & 7.0 & 5.6 & 3.9 & 3.6 \\
\hline 1994 & 6.8 & 7.9 & 7.2 & 5.8 & 6.9 & 7.5 \\
\hline 1995 & 7.1 & 8.9 & 7.4 & 5.8 & 7.4 & 6.4 \\
\hline 1996 & 4.4 & 5.0 & 6.1 & 5.7 & 3.8 & 4.9 \\
\hline \multicolumn{7}{|c|}{ (Output gap under different methodologies; in percent of GDP) 3 / } \\
\hline 1987 & $\ldots$ & $\ldots$ & 1.9 & 0.4 & -0.8 & -0.7 \\
\hline 1988 & $\ldots$ & $\ldots$ & 0.0 & 0.0 & 0.0 & 0.0 \\
\hline 1989 & $\ldots$ & $\ldots$ & -3.9 & -2.7 & -0.5 & -0.2 \\
\hline 1990 & $\ldots$ & $\ldots$ & -1.0 & -1.2 & 0.8 & 0.4 \\
\hline 1991 & $\ldots$ & $\ldots$ & -1.3 & 0.1 & 0.0 & 0.0 \\
\hline 1992 & $\ldots$ & $\ldots$ & 0.0 & 1.2 & 0.4 & 0.5 \\
\hline 1993 & $\ldots$ & $\ldots$ & -3.1 & -0.8 & 0.0 & 0.4 \\
\hline 1994 & $\ldots$ & $\ldots$ & -2.4 & 0.1 & -0.1 & -0.4 \\
\hline 1995 & $\ldots$ & $\ldots$ & -1.0 & 1.3 & -0.3 & 0.3 \\
\hline 1996 & $\ldots$ & $\ldots$ & -2.1 & 0.0 & 0.2 & -0.2 \\
\hline
\end{tabular}

Source: Staff calculations.

1/Based on 1990 prices; recent data based on 1995 prices show a similar trend, except for growth in 1991 which is now estimated to be around 1 percentage point lower.

2/ Refers to output of the business sector; other estimates for GDP.

$3 /$ Positive sign indicates actual output is above estimated potential output. 
$-11-$

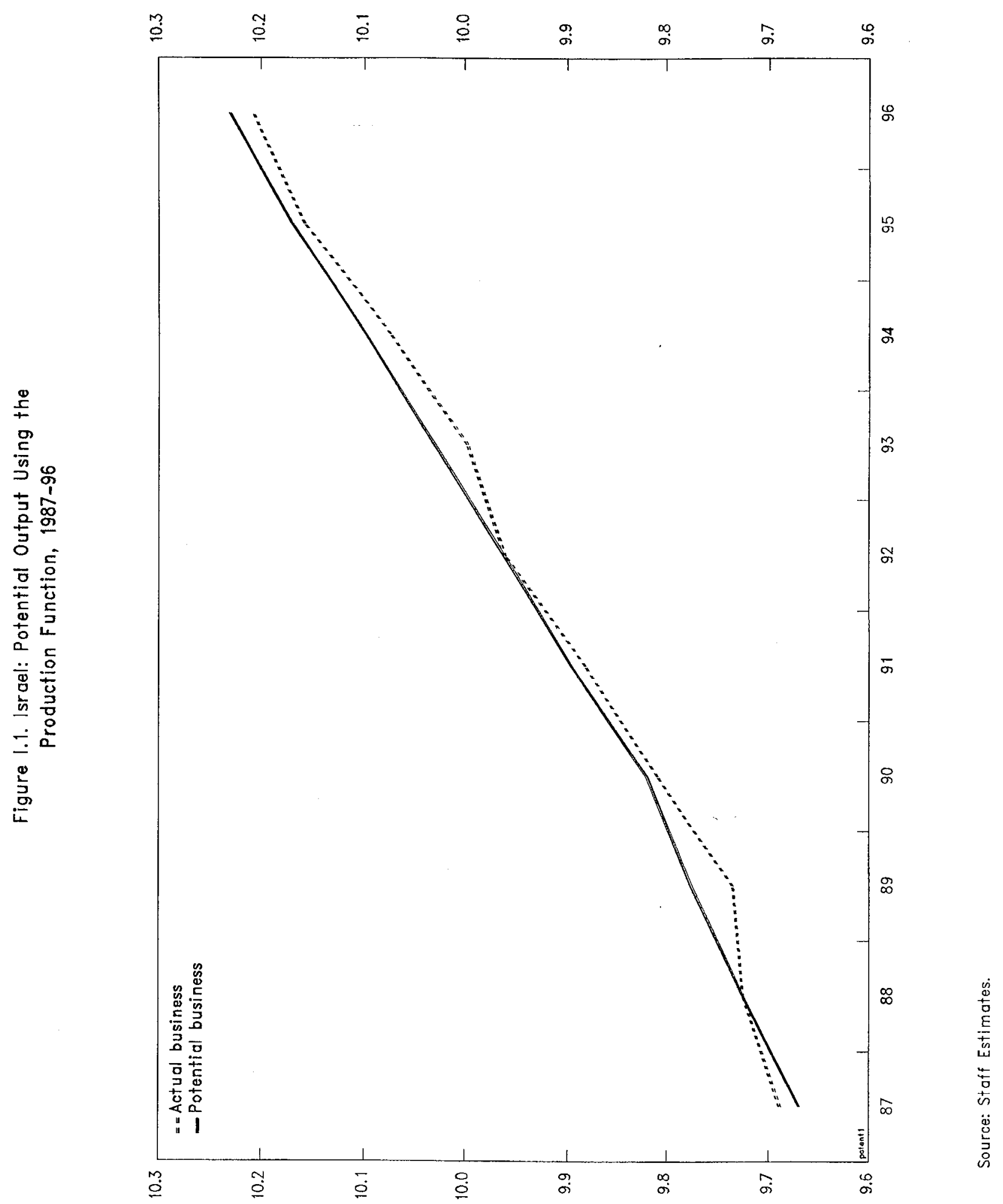




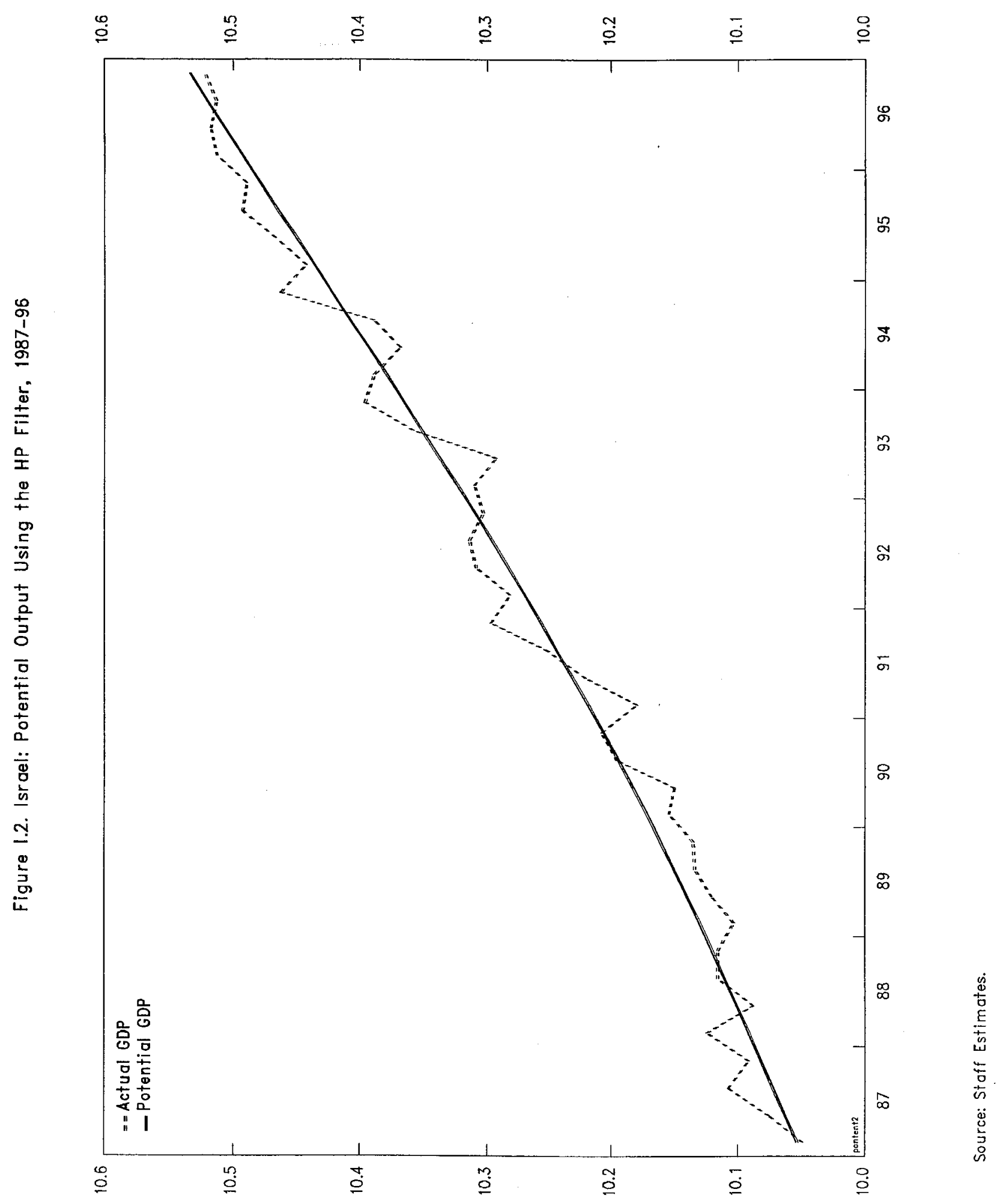


$-13-$

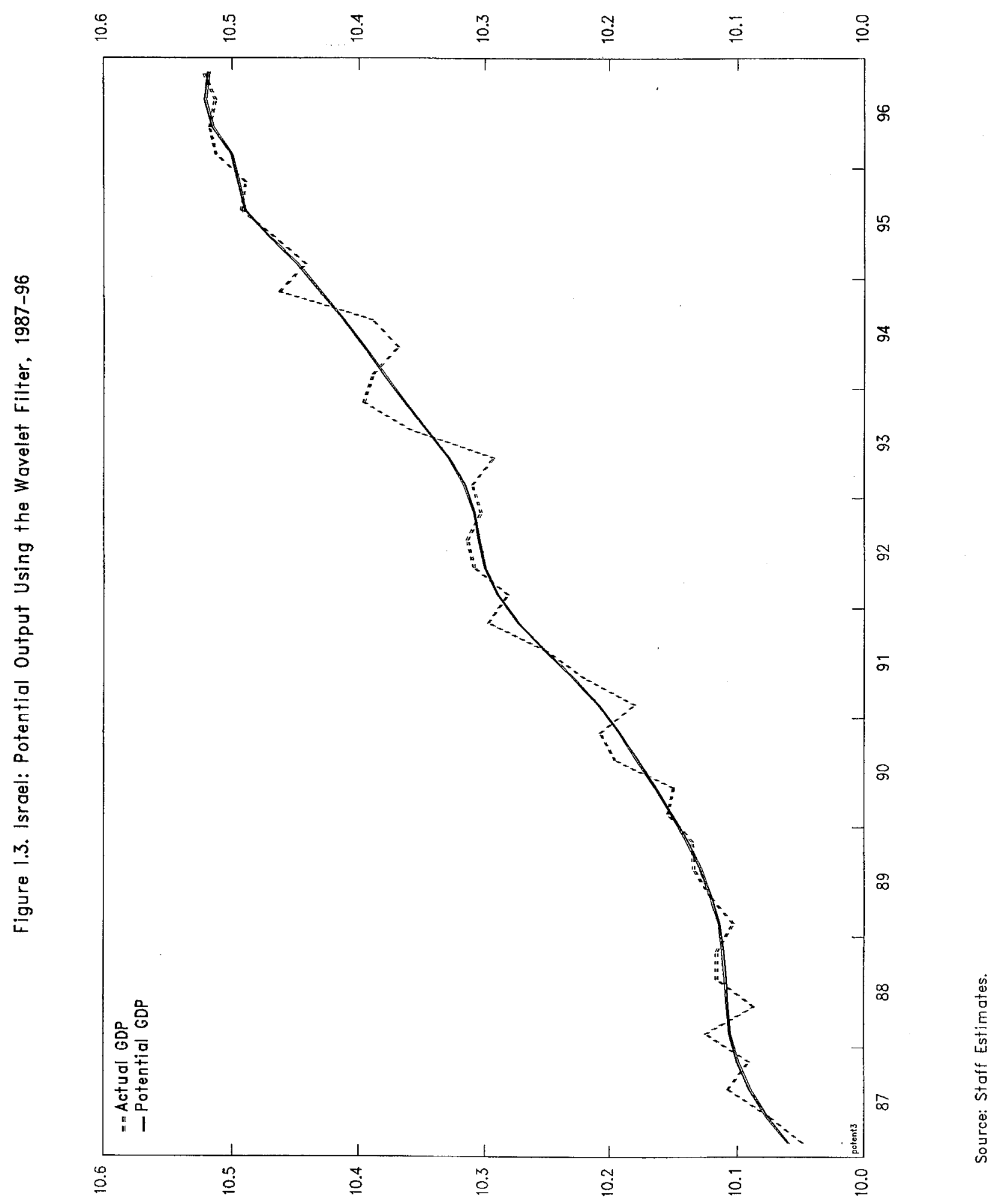


-14 -

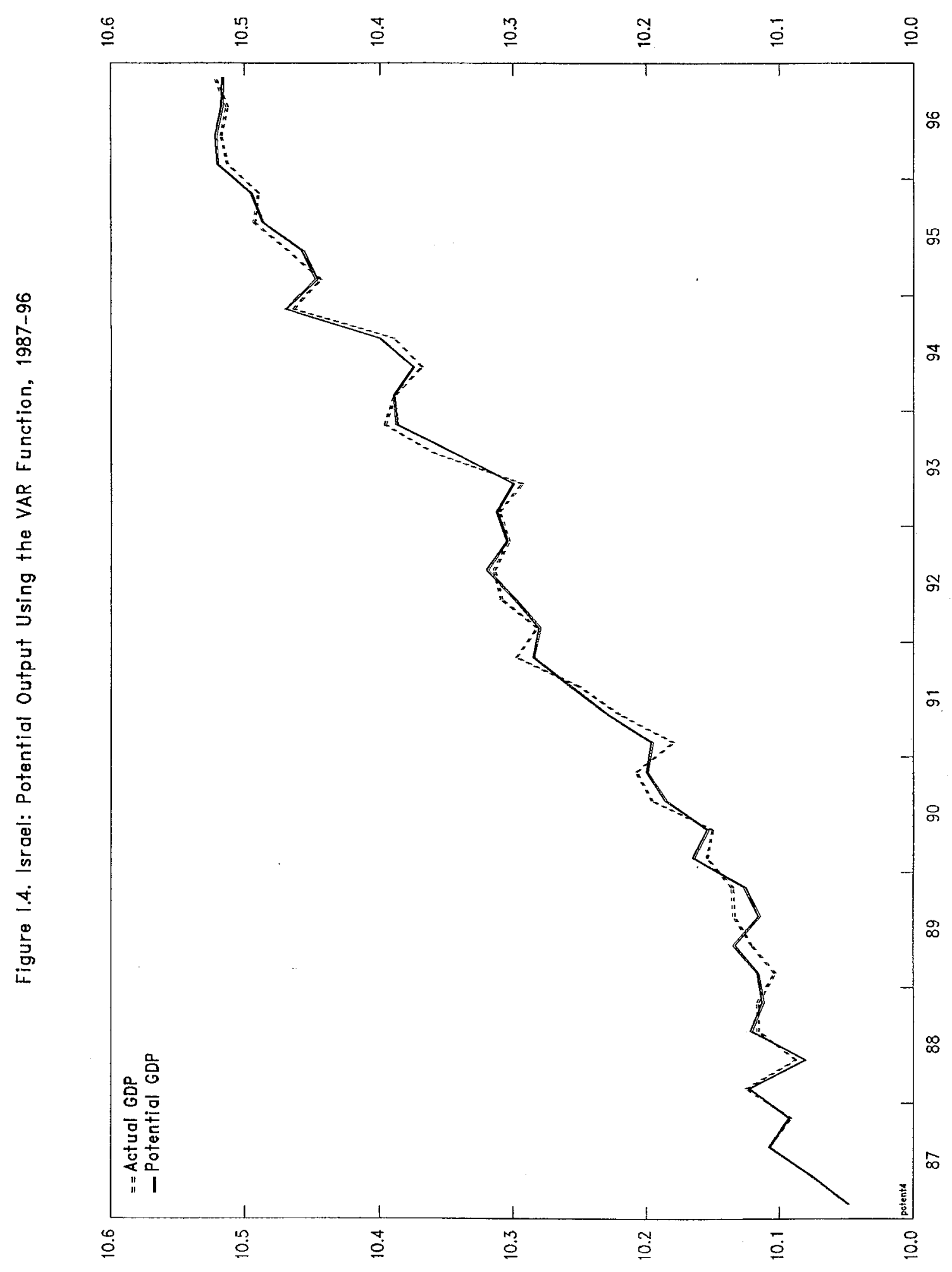

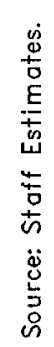




\section{References}

Blanchard, Olivier, and Danny Quah (1989), "The Dynamic Effects of Aggregate Demand and Supply Disturbances," American Economic Review, Vol. 79, pp. 655-73.

Burns, A., and W. Mitchell (1947), "Measuring Business Cycles," National Bureau of Economic Research (New York).

De Masi, Paula (1997), "IMF Estimates of Potential Output: Theory and Practice," in Staff Studies for the World Economic Outlook, (Washington, DC: IMF).

De Serrers, Alain, Alain Guay, and Pierre St-Amant (1995), "Estimating and Projecting Potential Output Using Structural VAR Methodology: The Case of the Mexican Economy," Bank of Canada Working Paper No. 95-2, March.

Donoho, D. L. (1993), "Non Linear Wavelets Methods for Recovery of Signals, Densities and Spectra from Indirect and Noisy Data," in I. Daubechies (ed.), Proceedings of the Symposia in Applied Mathematics (American Mathematical Society).

Processing. (1994), "De-noising by Soft Thresholding," IEEE Transactions on Signal and I. Johnstone (1992), "Ideal Spatial Adaptation via Wavelets Shrinkage," Technical Report No. 400, Department of Statistics, Stanford University.

Dupasquier, Chantal, and Alain Guay (1997), "A Comparison of Alternative Methodologies for Estimating Potential Output and the Output Gap," Bank of Canada Working Paper No. 97-5, February.

Theis, C.F. (1991), "Business Cycles and Black Holes," Critical Review, Vol 5, No 2 (Spring), pp 291-99. 


\section{TAX ReVenue Shortfalls IN 1995-97 ${ }^{11}$}

19. Since the early 1990 s, one objective of Israel's economic policies has been the consolidation of the public finances and maintenance of budgetary discipline despite the budgetary strain associated with large inflows of immigrants. However, in recent years, this objective has not always been met. In this study, the factors that have contributed to overruns in the budget deficit relative to its targeted level are examined. The study indicates that the main difficulty has stemmed from the revenue side, and details the various areas where problems have occurred. Finally, the study examines whether stable estimating equations for the major tax components can be established.

\section{A. Budget Deficit Targets and Outcomes in 1992-97}

20. The 1992 Deficit Reduction Law (DRL) attempted to impose control over the domestic component of the state deficit, setting specific targets for each year's domestic deficit to GDP ratio, with complete elimination of the deficit by $1995 .{ }^{12}$ However, during the 1994 budget process, the provisions of the DRL were relaxed, mandating only a requirement that future budgets target a domestic deficit that was below that targeted in the previous year, without specifying an end date for a balanced domestic budget.

21. In the first three years following the application of the original DRL, the domestic component of the state budget deficit was reduced from almost 5 percent of GDP in 1992 to 2 percent of GDP in 1994; in fact, the domestic deficits recorded in 1992-94 were smaller than forecast (see table below). However, the situation was reversed in 1995: despite a modest deficit target for 1995 of 2.8 percent of GDP (which was actually larger than the realized deficit in 1994), the domestic deficit was overshot by 0.4 percent of GDP. In 1996, the domestic deficit reached 4.6 percent of GDP, almost twice the targeted level.

\footnotetext{
${ }^{11}$ Prepared by Ling Hui Tan.
}

${ }^{12}$ The DRL excluded three types of transactions from the definition of the target deficit: (i) the foreign component of the state budget, which has primarily consisted of foreign grants on the revenue side (foreign revenue averaged about 4.6 percent of GDP and 12 percent of total state budget revenue during 1992-96) and foreign interest and defense imports on the expenditure side (foreign expenditure averaged about 4.7 percent of GDP and 10 percent of total state budget expenditure); (ii) net lending operations of the central government (primarily for housing assistance, the net quantitative impact of which has been minimal since 1994); and (iii) proceeds from the sale of government assets (the magnitude of which has been somewhat erratic from year to year). Furthermore, according to the accounting convention adopted by the state budget, the deficit is in essence an "operational" concept, as it excludes the nominal component of domestic interest payments. See Israel-Selected Issues and Statistical Appendix (SM/96/295, 12/4/96). 
Deficit Targets and Outturns, 1992-97 1/

(In percent of GDP)

\begin{tabular}{|c|c|c|c|c|c|c|}
\hline & 1992 & 1993 & 1994 & 1995 & 1996 & 1997 \\
\hline \multicolumn{7}{|l|}{ Target: } \\
\hline Domestic deficit & 6.2 & 3.2 & 3.0 & 2.8 & 2.5 & \\
\hline Overall deficit & $\ldots$ & $\ldots$ & $\ldots$ & $\ldots$ & $\ldots$ & 2.8 \\
\hline \multicolumn{7}{|l|}{ Outturn: } \\
\hline Domestic deficit & 4.9 & 2.4 & 2.0 & 3.3 & 4.6 & . \\
\hline Overall deficit (projected) & $\ldots$ & $\ldots$ & $\ldots$ & $\ldots$ & $\ldots$ & 2.8 \\
\hline
\end{tabular}

Source: Data from the Israeli authorities.

1/ The official target was changed from the domestic deficit to the overall deficit in 1997.

22. Prompted by the deficit overruns in 1995 and 1996, the government introduced several new measures in 1997 to improve budget monitoring and control in order to avoid overshooting the deficit target for a third consecutive year. The deficit target was changed from the domestic deficit to the overall deficit, which was set at 2.8 percent of GDP (and is to be reduced to 1.5 percent of GDP by 2001). In addition, the 1997 Budget was adjusted at the beginning of the year to better reflect the actual revenue base from the previous year (see below), and it was agreed that the Finance Ministry would inform the government of budget developments, itemized by component, at the beginning of each quarter.

23. Table II.1 presents a general outline of the state budget balance-programmed and actual-for 1995-97. As can be seen, expenditure during this period was generally kept in line with projections, and was even sometimes below the original target. The Ministry of Finance maintains centralized control over the spending ministries, specifying in detail their annual budgets, and it is common for additional expenditure cuts to be implemented during the year. Table II.1 indicates that the source of the budget difficulties in the last two years lay principally on the revenue side, particularly in the underperformance of tax revenues relative to the budget targets.

24. Table II.2 provides a comparison of budgeted and actual tax revenues at a disaggregated level for 1995-97. As indicated, realized tax revenues in 1995 and 1996 fell short of the budget target by around NIS 3-4 million (around 1.3 percent of final GDP in each case), with the shortfall primarily due to lower-than-anticipated collections of corporate taxes and VAT. Smaller shortfalls in purchase and excise taxes and property taxes have also 
occurred. A further shortfall in tax revenues on the order of NIS 4 million (equal again to 1.3 percent of estimated final GDP), due mainly to undercollection of VAT, is projected for 1997.

\section{B. Possible Factors Contributing to the Revenue Shortfalls}

25. The methodology employed by the Ministry of Finance to forecast tax revenue involves five main steps:

- $\quad$ Estimating the tax collection in the preceding year: Since the budget for year $\mathrm{t}$ is prepared before the end of year $t-1$, the tax revenue estimate for year $t$ is based on available data in year $t-1$ at the time of the forecast (typically 8-9 months) and an estimate for the remainder of the year $\mathrm{t}-1$.

- $\quad$ Adjusting for one-off factors that distort the base: Examples of such factors are exceptionally large tax refunds (such as NIS 500 million in tax refunds deferred from 1995 to 1996 , which were added back to the 1996 base when preparing the 1997 forecast) and tax transfers to the Palestinian Authority. ${ }^{13}$

- $\quad$ Estimating the effect of legislative changes: The relevant legislative changes are those planned for year $t$ or implemented during year $t-1$ but which will only have a full-year impact in year $t$; the effect is computed on the basis of activity and prices in year $t-1$.

- $\quad$ Estimating the effect of improved collection efforts. The forecast improvement in actual collections is entered as an assumption; no formal estimation procedure is employed.

- $\quad$ Estimating revenue growth due to economic activity: The sum of the first four steps yields the "forecast base" of revenue in year $t$. This forecast base is then multiplied by a real rate of change derived from a set of economic indicators including business sector product, public consumption, private consumption, durables imports, other imports, the number of workers and their real wage, and sales of new dwellings. Finally, the conversion to current prices in year $t$ is made on the basis of the expected increase in the average CPI.

\footnotetext{
${ }^{13}$ As part of the 1994 Paris Agreement, Israel forwards to the Palestinian Authority taxes collected from imports to the autonomous areas and trade with Israeli residents. Forecasts of these transfers have been very inaccurate-the actual final number of NIS 763 million in 1995 was three times higher than the original forecast-due to the paucity of data on the relevant transactions.
} 
26. To better understand the sources of recent difficulties, Table II.3 provides a breakdown of nominal tax revenue-forecast and actual-over the last three years, categorizing separately the effect on total tax revenue arising from errors in the forecast of the previous year's tax base, real growth, improvements in collections, legislative changes, and inflation. Both the forecast and actual figures, as well as the breakdown of forecast errors, were obtained from the Ministry of Finance.

\section{Overestimation of previous year's revenue}

27. As noted earlier, at the time of budget preparation, the previous year's tax revenue (which forms the basis for the budget forecast) is estimated using collections data for part of the year and forecasts for the balance of the year. Table II.3 indicates that this step has been a source of several forecasting errors in recent years. In particular, for the 1995 Budget forecast, the estimated base-year revenue (i.e., the revenue that would be collected in 1994), after adjusting for exceptional factors, was overestimated by 0.3 percent of GDP. For the 1996 forecast, the base-year revenue estimate was again overestimated, this time by 0.8 percent of GDP. In light of these experiences, for the 1997 budget year, the authorities made it a point to adjust their budget forecast at the start of the budget year once more complete data on the preceding year's revenue were available, which necessitated an expenditure cut of around 0.2 percent of GDP at the beginning of 1997. In consequence, there seems to have been virtually no error in revenue collections arising from this source in 1997.

\section{Overestimation of the revenue increase from economic growth}

28. As indicated in Table II.3, the contribution of real economic growth to real tax revenue growth was also a major factor in the revenue errors, accounting for an overestimate of 0.7 percent and 0.4 percent of GDP in 1995 and 1996, and a projected overestimate of 0.7 percent of GDP in 1997. In principle, this could be due to unexpected macroeconomic changes (e.g., if a correct elasticity of tax receipts to real GDP growth was used, but real growth turned out to be lower than anticipated), forecasting error (e.g., if real GDP growth was accurately forecasted but the assumed elasticity of tax receipts to real GDP growth was too high), or both.

29. For 1995 and 1996, the evidence points toward use of incorrect elasticities as the main source of the overestimation. Since real GDP growth was 2 percent higher than expected in 1995 (see table below) and was only $1 / 2$ percent lower than forecast in 1996 , unanticipated macroeconomic slowdowns were not the main reason for the initial overestimation of revenue. Instead, the data shown in Table II. 3 indicate that the implied elasticities at the time of the forecast were around 1.5 in 1995 and 1996, which, in retrospect, were too high; the actual elasticities came in on average closer to unity. ${ }^{14}$

\footnotetext{
${ }^{14}$ Simple regressions of the log of real tax receipts on the log of real GDP over the period 1986-94 yield elasticity estimates of between 1.0 to 1.2 .
} 
Macroeconomic Indicators, 1995-97

(Percentage change)

\begin{tabular}{|c|c|c|c|c|c|c|}
\hline & \multicolumn{2}{|c|}{1995} & \multicolumn{2}{|c|}{1996} & \multicolumn{2}{|c|}{1997} \\
\hline & Budget & Actual & Budget & Actual & Budget & Est.1/ \\
\hline Real GDP & 5.0 & 7.1 & 5.0 & 4.5 & 4.0 & 2.0 \\
\hline Real business sector GDP & 6.3 & 8.8 & 5.4 & 5.2 & 4.5 & 2.0 \\
\hline Real private consumption & 6.0 & 7.4 & 5.7 & 5.2 & 4.3 & 3.0 \\
\hline Real imports & 11.1 & 8.6 & 8.0 & 7.6 & 2.5 & 3.0 \\
\hline CPI & 8.9 & 10.0 & 9.3 & 11.3 & 11.1 & 8.6 \\
\hline
\end{tabular}

Source: Ministry of Finance, State Budget Proposal for Fiscal Year 1995 and 1996; Bank of Israel, Main Israeli Economic Data; data obtained through the Bank of Israel; and staff estimates.

1/ Authorities' estimates as of November 1997.

30. For 1997, however, a sharper-than-anticipated slowdown was likely the main reason behind the overestimation of the economic growth component of real tax revenue growth. Latest estimates by the Central Bureau of Statistics put the 1997 growth rate at 2 percent, significantly below the 4 percent growth envisaged in the budget papers. Hence, despite the improvement in the accuracy of the estimated base year collection and the lower implied elasticity of real tax revenue to GDP growth used (slightly less than unity, which is likely to be close to the actual elasticity), the net contribution of economic growth to tax revenue growth was overestimated by around 0.7 percent of GDP.

\section{Overestimation of revenue increase from improvements in tax collection}

31. The projected contribution of improved collection efforts to real growth in tax revenues appears in retrospect to have been optimistic in 1995 and 1996 (and in 1996 was of the wrong sign). Clearly there are inherent difficulties in quantifying this category, and the authorities have been gradually reducing the size of the projected contribution; improved collection efforts were expected to increase real tax revenues by 0.5 percent of GDP in the 1997 Budget, down from 1.1 percent of GDP in the 1995 Budget.

\section{Underestimation of revenue decline due to legislative changes}

32. Table II. 3 shows that legislative changes were a contributing factor to the tax revenue shortfalls in 1995, when their (negative) effect on revenue growth was underestimated by 0.3 percent of GDP. In this instance, unanticipated legislative changes (i.e., changes that were 
introduced after the budget had been passed) played a part, including the repeal of the capital gains tax on stock market transactions, reductions in property and real estate purchase taxes, and further reforms in personal income tax, notably, the award of a tax-credit point for married women, and the merging of two tax brackets that took effect in September. The net error in estimating the effect on tax revenue of legislative changes in 1996 and 1997 was minimal. ${ }^{15}$

\section{Overestimation of revenue increase due to inflation}

33. Finally, the assumed effect of inflation on nominal tax revenue was underestimated in 1995 and 1996: since the forecast inflation rates were below the actual rates by 1.1 percentage points in 1995 and 2 percentage points in 1996, nominal tax revenue was actually higher by 0.2 percent and 0.4 percent of GDP in these years. In 1997, however, it appears that the 11.1 percent inflation rate used in the budget forecast will turn out to have been too high, with a consequent reduction in actual nominal revenue due to this source by around 0.8 percent of GDP.

34. In summary, the main reasons for the deviations in total tax revenue in 1995 and 1996 were errors in forecasting the initial tax base and optimistic assumptions on the revenue impact of activity growth and in tax administration efforts. In 1997, however, these areas were addressed by the authorities and they have in consequence played only a minor role. Instead, the unexpected slowdown in actual real GDP and inflation were by far the main reasons for the decline in actual tax revenue relative to the forecasts presented in the 1997 Budget.

\section{Behavior of Tax to GDP Ratios Over Time}

35. In view of recent difficulties in accurately forecasting tax receipts, this section investigates whether a stable relationship can be found between tax/GDP ratios and cyclical and trend factors over time. Specifically, the tax/GDP ratios were regressed against the output gap (and other factors) using quarterly data from 1988-94, and then the equations were tested for parameter stability when the sample was extended to include data for $1995-96 .{ }^{16}$ The analysis focused on personal and corporate income taxes and VAT; as can be seen from Table II.2, these three categories are the most important components of tax revenue, making

\footnotetext{
${ }^{15}$ In 1996, the authorities overestimated the net negative effect of legislative changes (such as reductions in income, corporate, and property tax rates) in that year and in 1997, it appears that they may have underestimated the net positive effect of legislative changes (such as nonadjustment of income tax brackets and increases in the fuel tax and certain sales taxes).

${ }^{16}$ The quarterly data were obtained from Tables F-1 to F-4 of the Bank of Israel's Main Israeli Economic Data; (annual) corporate tax data were obtained from reports of the Revenue Authority, through the Bank of Israel.
} 
up 34 percent, 11 percent, and 34 percent of the total, respectively. Key features of these taxes are described in Box 1.

\section{Box 1. Key Features of the Major Taxes}

- Personal income tax (PIT): All individuals, resident or not for tax purposes, are subject to PIT on Israel-source income and income received in Israel. Since 1995, the rate structure has comprised four (inflation-adjustable) brackets of $15,30,45$, and 50 percent, with a minimum rate of 30 percent applying to passive (i.e., nonwage or nonbusiness) income. Tax is withheld at source on a variety of incomes and payments, including wages and national insurance contributions.

- Corporate income tax (CIT): All companies, resident or not for tax purposes, are subject to corporate tax on Israel-source income and income received in Israel. The CIT follows the classical system, i.e., profits are taxed at the corporate level and distributed dividends are taxed at the individual level. As of 1996, the regular rate of company tax is 36 percent.

- Value-added tax (VAT): A 17 percent VAT is levied on a broad range of goods (imported or domestically produced) and services (domestic only). Exports, unprocessed fruits and vegetables, and some tourism services are zero-rated; certain asset sales are exempt.

36. The economic cycle is measured by the output gap, which is defined as the difference between actual and potential (trend) output as a percentage of potential output. The output gap measure used here is based on potential output as estimated by means of the HodrickPrescott (HP) filter. ${ }^{17}$

37. Each tax/GDP ratio was regressed on up to four quarterly lags of the output gap (GAP) to capture cyclical effects, seasonal dummies, and up to four lags of the dependent variable. Also included were the $\log$ of real trend output $\left(\ln Y^{*}\right)$ to capture the effect of real income growth and a time trend to proxy for trend changes in the tax burden. ${ }^{18}$ The choice of this particular functional form was somewhat arbitrary; there is little theoretical guidance as to

${ }^{17}$ See Chapter I of this report for the derivation of this series for Israel.

${ }^{18}$ Statistical tests suggested that the tax/GDP ratios were nonstationary over the sample period. This could have reflected structural breaks in the series, or could have been due to the low power of such tests over short samples. 
the precise form of the relationship between tax receipts and the cycle, and the search for a preferred functional form involved some trial and error. ${ }^{19}$

38. The coefficient on the output gap represents the change in the tax/GDP ratio associated with a percentage point change in the output gap. A zero coefficient on the output gap would imply that tax receipts move in strict proportion to changes in contemporaneous GDP, with the tax/GDP ratio unaffected by movements over the cycle (i.e., that the elasticity between nominal tax receipts and GDP is unity). A negative coefficient on the output gap implies that tax receipts change less than proportionately with GDP over the cycle, while a positive coefficient implies tax receipts change more than proportionately with GDP over the cycle.

39. The equations were first estimated using data from 1988 to 1994 . The results are reported in Table II.4. For each of the taxes, the first column of figures shows the results from the regression with all the initial regressors; the second column shows a parsimonious specification from step-wise deleting insignificant variables from the initial set of regressors; and the third column shows the results after running the preferred specification on data that include 1995-96.

40. The results must be interpreted as illustrative only, due to a number of potential shortcomings and simplifications in the data and methodology. For example: the estimated relationship was a simple reduced form rather than a fully developed structural model which includes the determination of the tax base; the sample period used in the regressions was very short; the current GDP base may not have accurately reflected the underlying tax bases due to changes in the latter or to collection lags; and no attempt was made to account for changes in the tax structure or tax administration efficiency over time. ${ }^{20}$

\section{Regression results}

41. As reported in Table II.4, the elasticity of personal income tax receipts with respect to the cycle is smaller than one, as indicated by the negative coefficient on the contemporaneous

${ }^{19}$ Other specifications attempted included running the regression in log levels, with log GDP on the right hand side together with the output gap, and running the regression in differences.

${ }^{20}$ With respect to the last point, Israel's tax structure has evolved substantially over the last ten years. Reforms in personal income tax were implemented in 1987 (rate reductions), in 1990 (introduction of tax credits), and in 1994-95 (lowering of the minimum tax bracket, raising of the maximum bracket, and broadening of the brackets in between). The effective tax rate on undistributed corporate profits was reduced from over 60 percent to 45 percent in 1987, to 42 percent in 1990, and by 1 percent each year thereafter to eventually reach 36 percent in 1996. Finally, the VAT rate was increased from 16 percent to 18 percent in 1992 , but subsequently reduced to 17 percent in 1993 . 
cycle term. This is consistent with the usual observation that changes in wages and employment tend to lag the cycle, implying that personal income - the tax base-tends to fluctuate less than GDP itself. ${ }^{21}$ The coefficient on the log of real trend output is significantly positive, indicating evidence of real fiscal drag. The coefficient on the time trend is negative, indicating that holding constant other effects, the PIT/GDP ratio has declined over time, possibly reflecting the effects of the various structural reforms aimed at reducing the tax burden. However, these relationships do not appear to be stable: the equation fails the test for parameter stability when it is re-estimated using data over 1988-96.

42. There is no discernible relation between the CIT/GDP ratio and the output gap. This is unsurprising considering the lags involved in the declaration and collection of corporate taxes: in general, corporate taxes in Israel are calculated on the basis of past-year profits, and are paid "in advance" during the year they are due. Given the lags involved, it is difficult to make any a priori assumptions regarding the relation between the ratio of corporate taxes to (contemporaneous) GDP and the output gap in any given quarter. The coefficient on the log of real trend output is significantly positive, while the coefficient on the time trend is negative, reflecting the effect of the steady reduction in corporate tax rates since 1987. Unlike the case of PIT/GDP, no instability is detected in the preferred specification: the equation passes the test for parameter stability when it is re-run using data over 1988-96.

43. The VAT/GDP ratio is found to vary positively with (the second lag of the output gap but negatively with real growth in trend output. This latter effect might reflect the change in the structure of the economy toward more export oriented production, which are zero rated under the VAT. The equation also passes the parameter stability test.

44. In summary, the results of this empirical exercise point to the difficulty in establishing a stable pattern to the tax/GDP ratio for personal income taxes which could be usefully exploited to make more accurate revenue projections. This being the case, it is unsurprising for one to encounter fairly large errors in this major revenue term, suggesting the need for prudence in making revenue forecasts in such an uncertain environment. The tentative work here also suggests, however, that the corporate income tax and value-added tax equations presented may provide some scope for developing a stable forecast equation for these items.

\footnotetext{
${ }^{21}$ The contemporaneous effect is consistent with the observation that in Israel, income taxes are paid monthly by withholding, rather than filed annually with a one-year lag.
} 


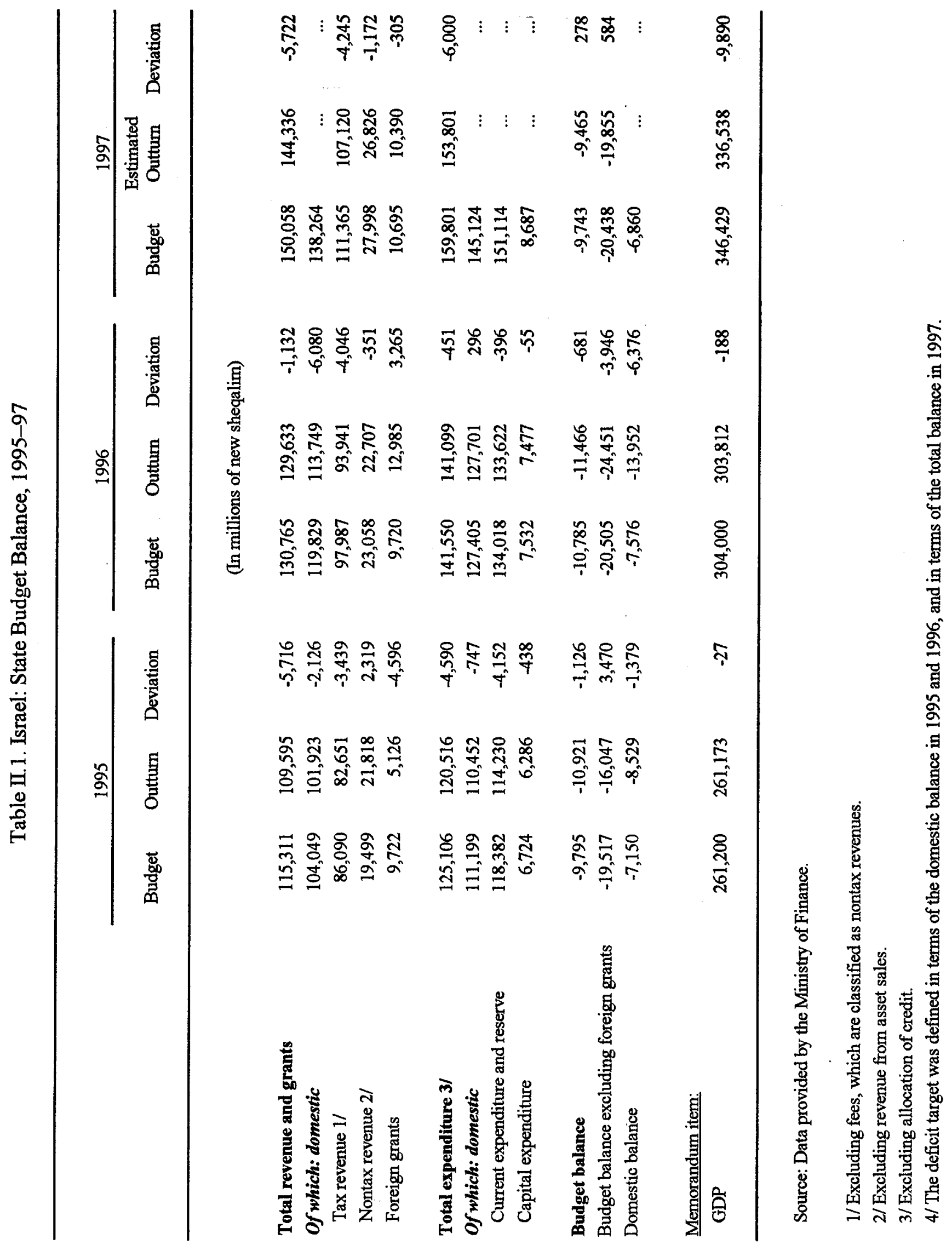




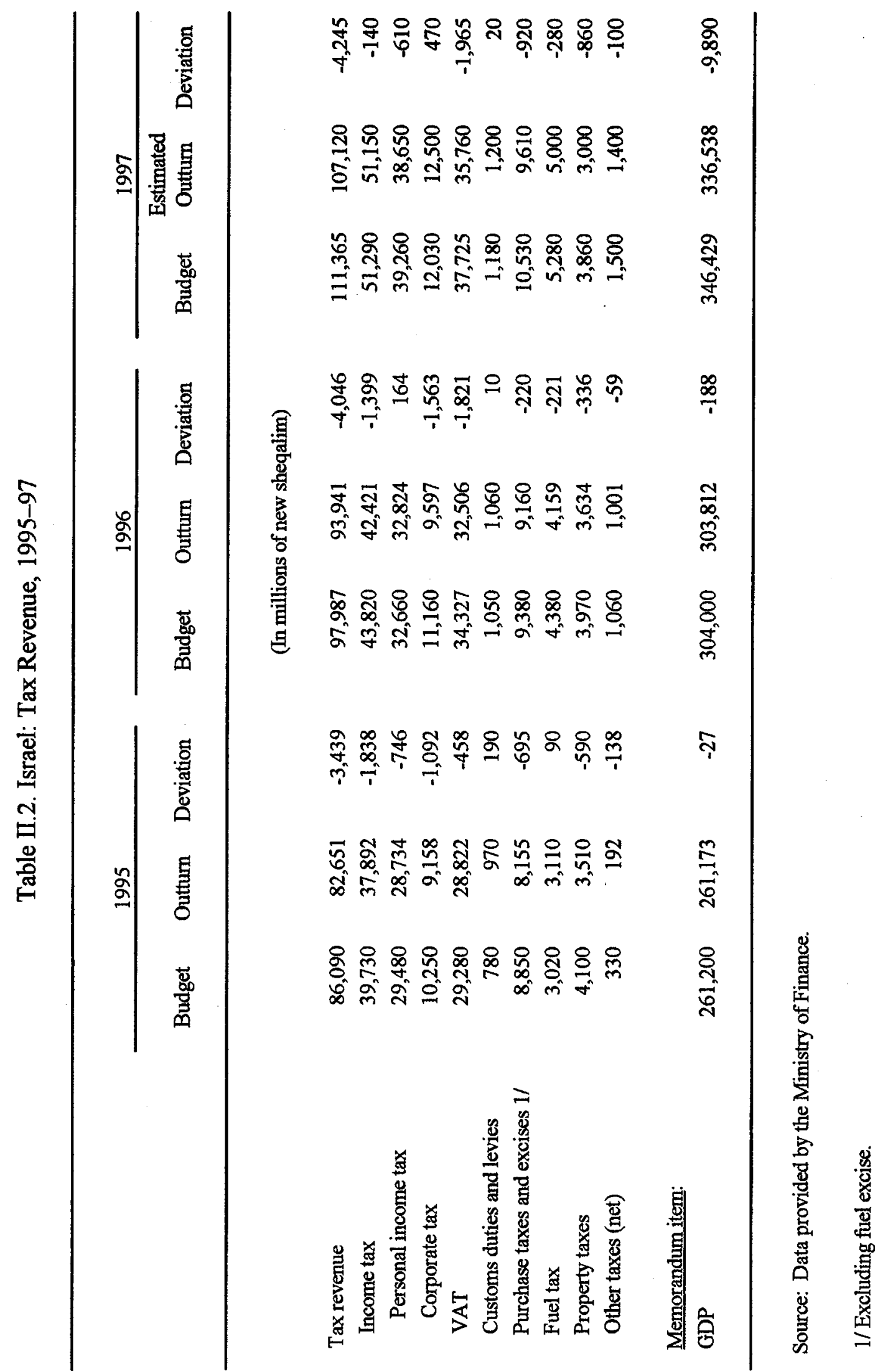


Table II.3. Israel: Tax Forecasts, 1995-97 1/

\begin{tabular}{|c|c|c|c|}
\hline & 1995 & 1996 & 1997 \\
\hline & \multicolumn{3}{|c|}{ (In millions of new sheqalim) } \\
\hline \multicolumn{4}{|l|}{ Forecast: } \\
\hline Base (previous) year revenue & $74,330^{\circ}$ & 85,400 & 95,400 \\
\hline Plus: Adjustment for exceptional factors $2 /$ & 0 & -400 & 500 \\
\hline Adjusted base year revenue & 74,330 & 85,000 & 95,900 \\
\hline Net revenue increase & 12,770 & 14,200 & 17,500 \\
\hline Real increase & 5,639 & 5,759 & 6,170 \\
\hline (Real growth, in percent) & $(7.6)$ & $(6.8)$ & (6.4) \\
\hline Due to economic growth & 6,079 & 5,779 & $3, \mathbf{5 7 0}$ \\
\hline (Contribution to teal growth, in percent) & $(8.2)$ & $(6.8)$ & (3.7) \\
\hline Due to improved collection & 800 & 500 & 500 \\
\hline (Contribution to real growth, in percent) & (1.1) & $(0.6)$ & $(0.5)$ \\
\hline Due to legislative changes & $-1,240$ & -520 & 2,100 \\
\hline (Contribution to real growth, in percent) & $(1.7)$ & (0.6) & $(2.2)$ \\
\hline Increase due to inflation & 7,131 & 8,441 & 11,330 \\
\hline (Price increase, in percent) & $(8.9)$ & (9.3) & (11.1) \\
\hline Current year's revenue & 87,100 & 99,200 & 113,400 \\
\hline$\frac{\text { Memorandum item: }}{\text { Real GDP growth }}$ & $(5.0)$ & $(5.0)$ & (4.0) \\
\hline \multicolumn{4}{|l|}{ Actual: } \\
\hline Base (previous) year revenue & 73,655 & 83,943 & 95,263 \\
\hline Plus: Adjustment for exceptional factors $2 /$ & -126 & $-1,496$ & 430 \\
\hline Adjusted base year revenue & 73,529 & 82,447 & 95,693 \\
\hline Net revenue increase & 10,414 & 12,816 & 13,407 \\
\hline Real increase & 2,783 & 3,144 & 4,767 \\
\hline (Real growth, in percent) & (3.8) & (3.8) & (5.0) \\
\hline Due to economic growth & 4,290 . & 4,621 & 1,227 \\
\hline (Contribution to real growth, in percent) & $(5.8)$ & (5.6) & (1.3) \\
\hline Due to improved collection & 623 & $-1,277$ & 1,190 \\
\hline (Contribution to real growth, in percent) & $(0.8)$ & (1.5) & (1.2) \\
\hline Due to legislative changes & $-2,130$ & -200 & 2,350 \\
\hline (Contribution to real growth, in percent) & (2.9) & $(0.2)$ & (2.5) \\
\hline Increase due to inflation & 7,631 & 9,672 & 8,640 \\
\hline (Price increase, in percent) $3 /$ & $(10.0)$ & (11.3) & (8.6) \\
\hline Current year's revenue & 83,943 & 95,263 & 109,100 \\
\hline \multirow[t]{2}{*}{$\frac{\text { Memorandum item: }}{\text { Real GDP growth }}$} & (7.1) & $(4.5)$ & (2.0) \\
\hline & \multicolumn{3}{|c|}{ (In percent of GDP) 4/ } \\
\hline \multicolumn{4}{|l|}{ Deviation (Actual minus Forecast): } \\
\hline Base (previous) year revenue & -0.3 & -0.5 & 0.0 \\
\hline Adjustment for exceptional factors & 0.0 & -0.4 & 0.0 \\
\hline Adjusted base year revenue & -0.3 & -0.8 & -0.1 \\
\hline Net revenue increase & -0.9 & -0.5 & -1.2 \\
\hline Real increase & -1.1 & -0.9 & -0.4 \\
\hline Due to economic growth & -0.7 & -0.4 & -0.7 \\
\hline Due to improved collection & -0.1 & -0.6 & 0.2 \\
\hline Due to legislative changes 5/ & -0.3 & 0.1 & $-0: 1$ \\
\hline Increase due to inflation & 0.2 & 0.4 & -0.8 \\
\hline Current year's revenue & -1.2 & -1.3 & -1.3 \\
\hline $\begin{array}{l}\text { Memorandum item: } \\
\text { GDP in current prices (in NIS millions) }\end{array}$ & 261,173 & 303,812 & 336,538 \\
\hline
\end{tabular}

Sources: Data from the Ministry of Finance, the Bank of Israch, and the Central Bureau of Statistics; and staff estimates. $1 /$ The data in this table differ marginally from those in Tables 1 and 2 due to the inclusion here of some nontax items. 2/ Due to extraordinary tax refunds and tax clearances to the Palestinian Authority.

3/ Percentage change in average $\mathrm{CPI} ; 1997$ figure is annualized nine-month average inflation rate. 


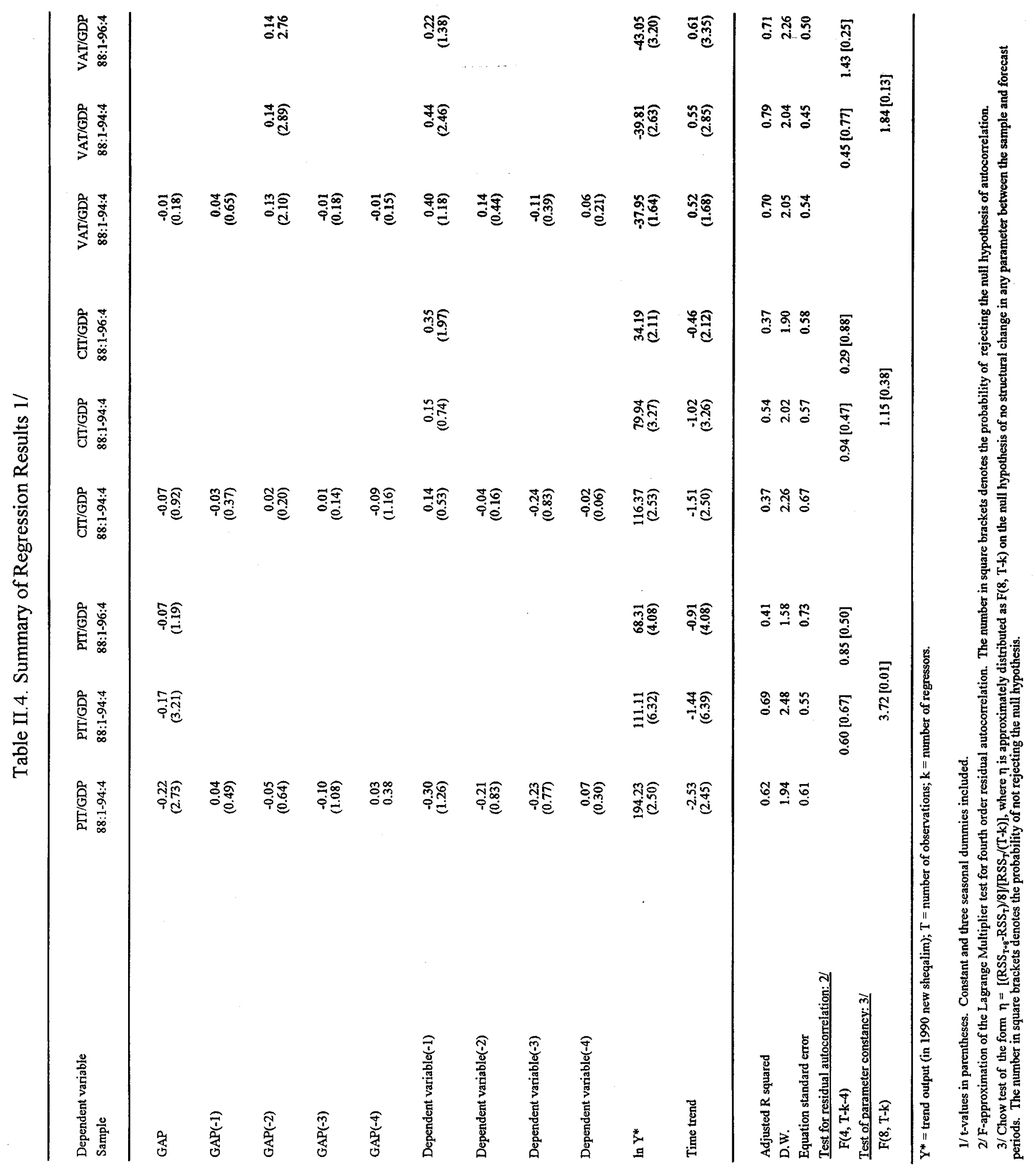




\section{VOLATILITY OF INTEREST RATES IN ISRAEL ${ }^{22}$}

45. For most of the 1990s, achieving a preannounced target inflation rate or range has been one of the goals of monetary policy in Israel. When Israel first announced an inflation target in December 1991, the inflation target was in the main viewed as a secondary goal, the achievement of which was necessary to support the crawling exchange rate band. However, after 1994, as the exchange rate band was steadily widened, meeting an annual inflation target became a major goal of monetary policy by itself.

46. A key feature of monetary policy in Israel during this period has been the considerable volatility of interest rates. This study first shows that official interest rates in Israel have been adjusted more frequently than in other countries-including countries where monetary policy is also guided by an inflation target - and that these adjustments per se have not led to a more stable inflation rate than in other countries. ${ }^{23}$ The study then discusses a number of reasons why this has been the case, focusing on the interlink between monetary with fiscal and exchange rate policies, as well as operational aspects of Israel's targeting approach, including the main indicator for measuring inflation expectations.

\section{A. Volatility of Interest Rates in Israel}

47. As noted, official interest rates have been volatile in Israel. Since 1994, when the inflation target became a separate goal for monetary policy, the nominal discount rate has been changed 28 times in 44 months, has moved within an 8 percentage point range, and the adjustment of official rates has changed direction six times (Table III.1). ${ }^{24}$ Further, the movements in the discount rate have tended to be large; the average size of the change has been 0.6 percentage points, while the standard deviation of these changes has been 0.41 . The monetary loan rate ${ }^{25}$ has moved very closely with this (volatile) trend, as have market lending rates, which reflects the importance of the discount rate as a key rate for the entire financial system. Since 1994, the real rate (the discount rate adjusted for movements in the CPI) has also fluctuated within an 8 percentage point band, though it has been somewhat more stable

\footnotetext{
${ }^{22}$ Prepared by David W.H. Orsmond.

${ }^{23}$ Clearly the ideal comparison would be a counterfactual exercise that examined the stability of the inflation path under Israel's actual operating regime relative to alternative operating mechanisms.
}

${ }^{24} \mathrm{~A}$ recent example in volatility was the June 1997 decline in interest rates by 1.2 percent, followed in August 1997 by an increase in rates by 0.7 percent. Official rates were also increased in the final quarter of 1995, fell back in early 1996, then rose again shortly thereafter.

${ }^{25}$ Loans from the monetary authorities to the banking sector. 
since 1996, remaining within a 4 percentage point band. Contrary to the intent, these movements in official interest rates have not in general kept the overall inflation rate fairly steady. Rather, the actual rate of inflation has fluctuated with a wide range, with a monthly standard deviation of the 12-month inflation rate equal to 0.71 . Similarly, four-quarter GDP growth has not in general followed a smooth path during the inflation targeting period (Figure III.1).

48. Official interest rates and inflation rates in Israel have also been more volatile compared to those in other countries in terms of the number of times official interest rates have been changed, as well as the number of times the direction of the changes in interest rates has been reversed (Figures III.2-III.3 and Table III.1). ${ }^{26}$ The standard deviation of the change in interest rates in Israel has also been relatively large, though not as large as in some countries which have had larger though much fewer changes in official rates. The degree of fluctuation in the 12-month inflation rate in Israel has also been substantially higher than in other inflation-targeting countries. As Table III. 1 indicates, a similar story emerges for a small sample of countries that have not followed an inflation targeting approach, including Greece that has had a similar average inflation rate as that in Israel over this period. The remaining sections of this note address reasons for the relatively high volatility in Israel's official interest rates.

\section{B. Reasons for Interest Rate Volatility in Israel}

\section{Consistency with other macroeconomic policies and clarity of monetary policy goals}

49. One of the key factors behind interest rate volatility in Israel has been the lack of consistency at times between monetary policy and other policies relevant for inflation. When the inflation targeting approach was introduced, insufficient emphasis was paid to the need to coordinate fiscal policy with monetary policy in order to meet the inflation target (Liederman and Bufman, 1996). Experience in other inflation-targeting countries suggests that, while the monetary authorities need not have goal independence, they must have a fairly high degree of instrument (or operational) independence if they are to meet an inflation goal (Debelle and Fischer, 1994). However, in an environment where the tightness of the fiscal stance changes repeatedly, there is in practice a significant constraint on the independence of monetary policy operations since the central bank is largely constrained to simply counteract as best as possible the demand impact from just one (large) source (Masson, et al, 1997). In Israel, following fiscal expansions in 1994 and 1996, the full burden to offset the associated impact on domestic

\footnotetext{
${ }^{26}$ Specifically, changes in the discount rate in Israel were compared with changes in the discount rate in Finland, Greece, Sweden, and the United States, and interbank market rates in Spain and the United Kingdom. The results are similar if the monetary auction rate in Israel is compared with changes in the repo and interbank rates in the other countries.
} 
demand fell on monetary policy, with consequent sharp changes in nominal and real interest rates. $^{27}$

50. The expansionary fiscal policy that was followed within the confines of an inflation target regime also carried other risks that can affect the level of interest rates. Firstly, it created a deleterious cycle between higher interest rates to offset the fiscal expansion and consequent higher deficits due to the increased debt service costs of the government (Griffiths, 1995). ${ }^{28}$ Secondly, at over 100 percent, Israel's high public debt/GDP ratio may have created expectations of future inflation which over time raised the risk premium incorporated into the interest rate on government debt as well as the expected inflation rate built into medium term wage contracts, placing additional burdens on monetary policy to meet the inflation target. Thirdly, the lack of coordination of monetary and fiscal policies during 1994-96 confused which arm of the authorities should be held accountable to meet the inflation target, which is an important aspect for sustaining private sector credibility within an inflation targeting approach and hence in the private sector's price expectations.

51. Further, rather than assigning one target for one policy, monetary policy in Israel is supposed to achieve multiple goals which are changed annually. For example, according to the Government of Israel Statement of Policy issued in September 1997, the guidelines for monetary policy in 1998 are to achieve an inflation rate between 7-10 percent, support economic growth at the rate of increase in potential output (specified at 5 percent per annum), and to maintain the exchange rate within its band. No clear priority is specified between these three goals in the Statement, and in the event of a conflict, priority is to be established by the government. ${ }^{29}$

52. Potential conflicts between different tasks assigned to monetary policy have at times complicated monetary management in the past few years. For example, during 1997 large capital inflows have kept the exchange rate at or very close to the appreciated limit of the band for much of the year. Given the inability of the Bank of Israel (Bol) to reduce interest rates to offset such pressures due to the consequences this would have on its ability to meet the inflation target, the monetary authorities first undertook extensive intervention to hold the exchange rate within its band and then had to sterilize the liquidity so created in order to

\footnotetext{
${ }^{27}$ By way of example, in 1994 the government raised controlled prices by 12 percent and government wages by 27 percent, actions that were not consistent with meeting the annual announced inflation target for that year of 8 percent.

${ }^{28}$ Sargent and Wallace (1981) outline a formal presentation of the "unpleasant" dynamics concerning the interplay of monetary policy, high levels of public debt, and inflation.

${ }^{29}$ The Bank of Israel has argued that there is no inconsistency between the government's long run economic growth goal and the inflation target since achieving a stable and low inflation environment is the best way to maximize the rate of growth of output.
} 
maintain the inflation target, which in turn put upward pressure on official interest rates and provided an incentive for further capital inflows. Such a situation clearly hampers the ability of the monetary authorities to follow an independent monetary policy that can be primarily aimed at achieving the inflation target, adds to the volatility of interest rates as monetary policy is tightened or loosened to meet other policy goals, and sends confused signals since it is not clear the criteria the authorities use at any point in time to decide which of the nominal anchors will take precedence. ${ }^{30}$

\section{Targeting overall versus underlying inflation}

53. A key issue under an inflation target regime is to define exactly what prices should and will be targeted. In Israel, the inflation target is defined in terms of overall inflation. Since prices of certain items in Israel are very volatile, this practice makes monetary policy hostage to fluctuations in such prices. Fruit and vegetable prices (4 percent of the CPI) are volatile for seasonal reasons as well as security concerns that result in closures of the border between Israel and the West Bank and Gaza. Changes in the user cost of housing services ( 21 percent of the CPI) are measured by changes in housing prices-the price of the housing asset, not rents-which are quoted in dollars, making them sensitive to movements in the exchange rate and to asset price booms and busts. ${ }^{31}$ Table III. 2 and Figure III. 4 indicate the extreme volatility of these items; indeed, the standard deviation of the underlying inflation rate that excludes fruit and vegetable and housing prices is only one quarter of that for the overall CPI. Clearly, the more volatile the targeted inflation indicator, the more frequent and large will be the interest rate changes necessary to keep inflation measured by that indicator within the target.

54. Despite the volatility of the overall inflation index, the authorities argue it is necessary to use the overall index due to the prevalence of indexation based on the overall CPI in Israel. However, this effect may not now be as important as it was in earlier years, and in any case there may be room for adopting a narrower target, at least for operational purposes in guiding monetary policy. ${ }^{32}$ Specifically, wage setting arrangements in Israel's private sector are now

\footnotetext{
${ }^{30}$ With the exception of Spain, every other country that has adopted an inflation targeting regime has a flexible exchange rate. Spain has a wide exchange rate band, and the inflation target is intended to be consistent with progression into the EMU.

${ }^{31}$ The CPI includes housing services of owner occupied homes by imputing an interest rate of 4 percent of their value. The housing market in the 1990s has been volatile following the wave of immigration.

${ }^{32}$ Several countries, such as Canada, use a different definition of inflation for the purposes of guiding monetary policy than that used to define the inflation target. See Annex I to this study.
} 
largely in the private sector's hands; legislatively, the effect of changes in the overall CPI on wage increases is only at the margin (private and public wages are increased by 85 percent of just the excess of the CPI above an annual rate of 5.5 percent). Further, given that the mean of the changes in prices of fruits and vegetables is similar to those for the underlying index, this highly volatile category could safely be excluded from the definition used for operational purposes - if not for the announced inflation target itself.

55. With reference to the housing component, as the authorities have noted, the cost of housing has tended to rise at a rate that is around 6 percentage points higher than the underlying inflation rate (see Frenkel, 1996). Ideally; therefore, some measure of the cost of housing services should be included in the operational index in order that the change in the relative price of housing services is not omitted from consideration in the setting of monetary policy. In most countries, this effect is captured by including rents in the inflation index, which would be a "first-best" practice for Israel as well. Indeed, the Israeli Central Bureau of Statistics announced in December 1997 that the housing component of the CPI will be changed to reflect rental prices starting from January 1999. In the interim, given the extreme volatility of the current housing asset measure, its large weight in the overall CPI, and the likely weak link between changes in housing asset prices and the user cost of housing services, it would be best to use an index that excludes the volatile housing price component as the operational guide for monetary policy, and then simply take into consideration the average increase over time in housing service prices relative to the rest of the underlying CPI basket. ${ }^{33}$

\section{Length of period over which targets are set}

56. In Israel, while a long term goal of reaching average OECD country inflation by 2001 has been accepted, the inflation target is only specified one year at a time, and is only announced in the fall of the preceding year. This implies that, when the new inflation target is announced, there is at most only a 16-month window for monetary policy to achieve the inflation target. Given the long lags by which monetary policy has its impact, and the difficulty of discovering the likelihood of deviations between actual inflation and the target sufficiently ahead of time, this approach frequently encounters the need for large interest rate changes in response to small projected deviations in the current year's inflation outlook. ${ }^{34}$ Further, not only does adjusting interest rates to meet short-term changes in the inflation outlook lead to frequent adjustments by itself, it risks introducing additional volatility as rates might have to be adjusted by ever-wider magnitudes to compensate for their own lagged effects (see Holbrook, 1972).

\footnotetext{
${ }^{33}$ The United Kingdom excludes housing from both the operational measure and the definition of the target itself; see Annex I.

${ }^{34}$ For example, in August 1997 the discount rate was raised by 0.7 percent, apparently to offset a projected slight move in inflation outside of the 1997 range, mainly due to the impact of housing prices when the exchange rate depreciated in June.
} 
57. One way to resolve the problem would be to set a 2-3 year inflation target to guide monetary policy decisions. ${ }^{35}$ In the same vein, the monetary authorities could adopt a longerterm perspective and act on interest rates at each decision point on the basis of an assessment of what is required to eliminate the estimated gap between the desired inflation rate 18 months to 2 years hence and the inflation rate that would materialize if interest rates were frozen at their prevailing level. The BoI has progressively moved to adopt this perspective.

\section{Israel's measure of inflation expectations}

58. Monetary policy actions should be forward looking, and hence be guided by the prognosis for inflation-including inflation expectations, given their effect on current wage and price decisions - rather than by current or past inflation levels. Indeed, one of the benefits of adopting an inflation target approach is said to be that it focuses policy instruments on a systematic assessment of expected future inflation (Masson, et al, 1997).

59. In developing their forecasts, some central banks use a model-based approach to determine the underlying causes and projections of inflation, basing changes in monetary policy on the results of such models as well as on a wide variety of indicators. While the BoI has an annual model to forecast inflation over the medium term, to estimate inflation pressures in the short run it relies extensively on a measure of inflation expectations derived from the difference in the yield of 12-month indexed and nonindexed bonds (Figure III.5). ${ }^{36}$ However, there may be problems with relying too heavily on this inflation expectations as a guide to monetary policy.

60. Firstly, instead of being a forward measure, statistically approximately 60 percent of the level of the expectations measure is based on previous rather than projected inflation. ${ }^{37}$ In practice, the weight given past inflation is even higher since inflation in the most recent

${ }^{35}$ Using a longer term horizon in the setting of monetary policy can also assist in dealing with supply shocks. The use of a longer term operational horizon would quarantine supply shocks from impacting on contemporaneous monetary policy decisions.

${ }^{36}$ The authorities note: "In the conduct of monetary policy, we make extraordinary use of inflation expectations as measured from financial variables. Since we have indexed and nonindexed for the same maturity and for the same government, we can read inflationary expectations over the next twelve months". See Frenkel (1996).

${ }^{37}$ Specifically, when the expectations measure is regressed against a constant and the 12-month to inflation rate for monthly observations over the period 1992-97, the coefficient on the 12-month inflation rate is 0.58 with a t-statistic of 13.5 , and the constant is 4.07 with a $t$-statistic of 7.4. The adjusted R-squared is 0.70 .Yariv $(1995, \mathrm{p}$. 11) also notes "the process of forming expectations is to a considerable extent adaptive, as expectations are adjusted only after a new level of inflation has been experienced for a while." 
12 months is also a separate variable that is used as an indication of the current inflation environment (see Sokoler and others, 1997). This would be a valid basis for guiding current decisions on monetary policy if previous inflation was indeed a good predictor of future inflation pressures. However, a regression of future inflation as a function of current 12-month inflation rates shows no close relationship between the two at all; the coefficient is insignificant and the regression R-squared adjusted statistic is zero. Similarly, Figure III.5 shows that while the inflation expectations measure has closely followed previous inflation-with a mean of the difference in these two measures just 0.7 percentage points - the difference between the expectations measure and inflation over the following 12 months has oscillated widely - with a mean of 2.7 percentage points-further implying that past inflation is not a good guide of future inflation, especially in measuring expected turning points in inflation ${ }^{38}$ Table III. 3 indicates that the expectations measure is not a good predictor of future underlying inflation either. Hence, changes in interest rates that are based on this measure of inflation expectations would be unlikely to stabilize future inflation. ${ }^{39}$

61. Secondly, the relative price of indexed and nonindexed securities will in part be determined by their relative supply and demand rather than just by the private sector's inflation expectations. In particular, changes in the supply of nonindexed bills can have a significant impact on their price for reasons that relate to the nonperfect substitutability and relative supply of such bonds in the market rather than to changes in the expectations of inflation. Further, there can also be changes in demand for different types of bonds due to the different ways that they are taxed. The return from nonindexed treasury bills is not taxed for households, but for indexed bonds, while some investors are exempt (such as provident and pension funds), all others pay a 35 percent tax on the coupon. In calculating the inflation expectation measure in Israel, the authorities assume that holders of short term bonds are taxable.

\footnotetext{
${ }^{38} \mathrm{Of}$ course, a good predictor of inflation that is useful for policy purposes may not necessarily reflect well the actual future inflation rate if policy responds to the inflation forecast. Ideally, the expectations measure would be compared against future recorded inflation with an unchanged policy environment. Nonetheless, one would not expect that an expectations measure that accurately predicted future inflation pressure in the absence of policy changes would follow closely actual inflation over the past 12 months, as this measure of inflation expectations appears to do in Israel.

${ }^{39}$ Recent work at the BoI suggests that, along with past inflation, since 1994 the real discount rate has played a significant role in determining the private sector's inflation expectation; see Sokoler and others (1997). In discussing the pre-1994 experience, this paper also notes that "relying too much on market-based expectations as a guide to policy can be problematic. This is so particularly if there is a strong adaptive element in the formation of these expectations" (p.11).
} 
62. While the authorities acknowledge that this assumption may introduce a bias in the calculated level of expectations, they argue that this bias should remain fairly steady over time and hence will not distort changes in the inflation expectations measure (Yariv, 1995). However, changes within the financial system may call this assumption into question, including the recent pension fund reform (where 30 percent of pension assets are now invested in market securities rather than in earmarked treasury securities that carry a favorable real return), and proposed efforts to make some domestically traded bonds tax free for foreigners. Since these reforms will likely alter the relative desire of nontaxable entities to hold one of these types of bonds, there may be a consequent adjustment in relative prices for reasons that are not related to changes in expected inflation.

63. Thirdly, risk aversion toward inflation will bias the level of this inflation expectations indicator; the higher the perceived volatility of inflation, the higher the risk factor that will be reflected in the price of nonindexed bonds. Hence, the relative price of indexed to nonindexed securities will not just reflect expected levels of inflation, but also include a factor that depends on the volatility of inflation around its mean (Fama, 1975). ${ }^{40}$ While the authorities assume that, to the extent such a risk factor exists, it remains constant over time, this may not be true, especially since the volatility of inflation has changed during the period (Table III.2).

64. Finally, and potentially most importantly, an inflation expectations measure derived from private sector behavior on which monetary policy is based may be impaired by the very fact that the monetary authority responds to it. In a recent paper, Bernanke and Woodford (1997) show that targeting private sector forecasts is problematic once these forecasters incorporate the central bank's feedback rule into their forecast. In particular, the relative price of indexed and nonindexed bonds must in turn be a function of expected changes in monetary policy, especially since market participants know that the difference in the price of these securities will be used by the monetary authorities as the measure of inflation expectations and will hence form the basis for changing monetary policy. Thus, there is a circularity in the stance of monetary policy which no longer targets the private sector's expected evolution of prices, but is affected by the private sector's perceived changes in monetary policy. Bernanke and Woodford (1997) show in such circumstances added interest rate volatility is a likely result.

65. To offset these problems, it is important that a central bank develops and responds to a model of the structural determinants of both short- and medium-term inflation pressures based on a set of relevant variables, and places a high weight on measures of inflationary pressures that are impervious to whether the financial markets know them or not (like the output gap). Variables that have been used in other countries to guide the setting of monetary policy

\footnotetext{
${ }^{40}$ Presumably reflecting in part the risk factor, the Australian Treasury, Bank of Canada, and Bank of England report that the difference between indexed and nonindexed debt consistently overpredicts actual and survey based inflation (Price, 1997), in the U.K. case by 1.7 percentage points (see Cote, et al, 1996).
} 
include the potential output gap, capacity utilization, prevailing unemployment rates, current wages, import prices, changes in the exchange rate, and raw material and intermediate goods prices. Monetary aggregates, surveys of inflation, and private sector inflation expectations derived from bond prices have also been used as important indicators, and are also considered in Israel ${ }^{41}$ Armed with its own analysis of inflation pressures, credibility and accountability can then be enhanced if the central bank regularly publishes a report on inflation pressures and the inflation outlook, which can also help to explain the nature of the inflation target regime to the public. The BoI is in fact in the process of initiating the publication of a regular report on the inflation outlook from 1998.

\section{Conclusions}

66. This study illustrates that, relative to other countries, volatility in nominal and real interest rates has been high in Israel but this has not led to a relatively stable inflation path. The contribution of fiscal and exchange rate polices which were not well coordinated with monetary policy directed at the inflation target has no doubt played a major role in this volatility. Closer coordination between fiscal and monetary (and exchange rate) goals as well as clearly establishing the primacy of the inflation target in the event of a conflict with other goals for monetary policy would be a first best outcome to lower volatility and would also help to anchor private sector price expectations and maximize credibility.

67. The study also notes that operational aspects in Israel's inflation targeting regime may have been part of the cause of the volatility in official rates. In this regard, the discussion makes the case for using the underlying rather than the overall inflation rate (at least in setting the operational target that guides monetary policy decisions) and for setting explicit multi-year targets that outline the adjustment path from the current inflation level to a medium term (lower) level. Further, to reduce volatility in interest rates, the intermediate target should be the monetary authorities' own structural forecast based on the fundamental determinants of inflation, with minimal use of variables that are themselves affected by perceived changes in monetary policy.

\footnotetext{
${ }^{41}$ Klein (1997) reports that demand for M1 has a unitary elasticity of money demand with respect to changes in economic activity, and an interest rate elasticity of money demand of negative 0.2 . Further, changes in M1 in excess of demand generated by economic activity affect prices with a 2-3 quarter lag. However, Offenbacher (1996) claims that M1 was a good predictor of inflation in 1994 but not in 1996.
} 
Table III. 1. Indicators of Monetary Policy Volatility: January 1994 to August 1997

\begin{tabular}{lcccccc}
\hline Country & \multicolumn{3}{c}{ Discount rate } & \multicolumn{2}{c}{ Inflation rate } \\
\cline { 2 - 3 } & $\begin{array}{l}\text { No. of } \\
\text { Changes }\end{array}$ & $\begin{array}{l}\text { No. Changes } \\
\text { in Direction }\end{array}$ & $\begin{array}{l}\text { Standard } \\
\text { Deviation 1/ }\end{array}$ & $\begin{array}{l}\text { Average } \\
\text { Rate (\%) }\end{array}$ & $\begin{array}{l}\text { Standard } \\
\text { Deviation 1/ }\end{array}$ \\
\hline Israel & 28 & 6 & 0.41 & 11.0 & 0.71
\end{tabular}

European inflation-targeting countries

$\begin{array}{lrllll}\text { U.K. } & 12 & 3 & 0.33 & 2.8 & 0.24 \\ \text { Sweden } & 10 & 2 & 0.92 & 1.4 & 0.43 \\ \text { Finland } & 7 & 0 & 0.06 & 0.9 & 0.33 \\ \text { Spain } & 20 & 2 & 0.35 & 4.0 & 0.21\end{array}$

Other countries

$\begin{array}{lrrrrr}\text { U.S.A. } & 8 & 1 & 0.22 & 2.8 & 0.17 \\ \text { Greece } & 10 & 1 & 0.63 & 8.9 & 0.47\end{array}$

Source: IMF, International Financial Statistics; and staff estimates.

1/ Standard deviation of the monthly first difference in the discount rate and in the 12-month inflation rate. 
Table III. 2: Measures of Inflation Volatility

(12 month data; in percent) $1 /$

\begin{tabular}{|c|c|c|c|c|c|c|}
\hline \multirow{2}{*}{\multicolumn{2}{|c|}{$\begin{array}{r}\text { Annual } \\
\text { inflation } \\
\text { target }\end{array}$}} & \multicolumn{3}{|c|}{ General CPI Indicators } & \multicolumn{2}{|c|}{ Price Components } \\
\hline & & \multirow{2}{*}{$\begin{array}{r}\text { Overall } \\
16.4\end{array}$} & \multicolumn{2}{|c|}{$\begin{array}{l}\text { Excluding Excluding } \\
\text { fruit and fruit, vegetables, } \\
\text { vegetables and housing }\end{array}$} & \multirow{2}{*}{$\begin{array}{r}\begin{array}{l}\text { Fruit and } \\
\text { vegetables }\end{array} \\
18.9\end{array}$} & \multirow{2}{*}{$\begin{array}{r}\text { Housing } \\
23.0\end{array}$} \\
\hline 1988 & $\ldots$ & & 16.2 & 14.7 & & \\
\hline 1989 & $\ldots$ & 20.7 & 21.7 & 18.6 & 4.4 & 35.2 \\
\hline 1990 & $\ldots$ & 17.6 & 18.4 & 14.9 & 4.9 & 31.6 \\
\hline 1991 & $\cdots$ & 18.0 & 18.2 & 15.2 & 14.3 & 28.1 \\
\hline 1992 & 14.5 & 9.4 & 9.2 & 10.4 & 14.2 & 5.4 \\
\hline 1993 & 10.0 & 11.2 & 11.9 & 8.1 & -1.2 & 23.7 \\
\hline 1994 & 8.0 & 14.5 & 12.7 & 9.8 & 56.1 & 23.6 \\
\hline 1995 & $8-11$ & 8.1 & 10.0 & 8.8 & -24.6 & 13.6 \\
\hline 1996 & $8-10$ & 10.6 & 10.8 & 10.1 & 4.9 & 13.2 \\
\hline 1997 & $7-10$ & 8.7 & 8.8 & 8.7 & 6.0 & 12.0 \\
\hline \multicolumn{7}{|l|}{ Average: } \\
\hline $1988-97$ & & 13.5 & 13.8 & 11.9 & 9.8 & 20.9 \\
\hline $1992-97$ & & 10.4 & 10.6 & 9.3 & 9.2 & 15.3 \\
\hline 1994-97 & & 10.5 & 10.6 & 9.4 & 10.6 & 15.6 \\
\hline \multicolumn{7}{|c|}{ Standard Deviation: } \\
\hline $1988-97$ & & 4.5 & 4.5 & 3.6 & 20.2 & 9.6 \\
\hline $1992-97$ & & 2.3 & 1.5 & 0.9 & 26.5 & 7.2 \\
\hline 1994-97 & & 2.9 & 1.6 & 0.7 & 33.5 & 5.4 \\
\hline \multicolumn{7}{|c|}{ Memorandum: } \\
\hline Weight in & PI basket (in percent) & & & & 3.7 & 20.7 \\
\hline
\end{tabular}

Sources: Central Bureau of Statistics; and staff estimates.

1/ 1997 data for period through to September. 


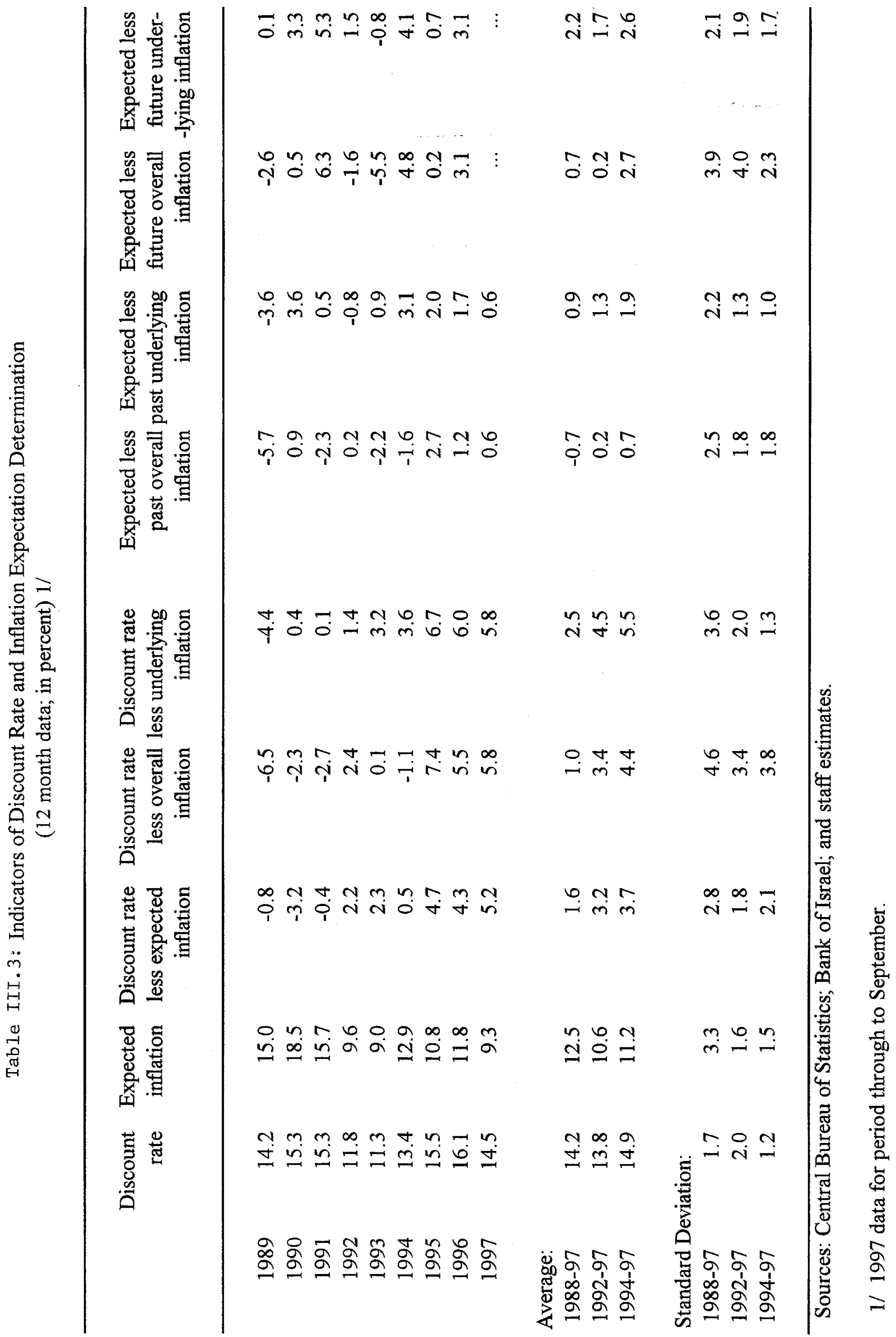


Figure III.1. Israel: Measures of Volatility, 1993-97

NOMINAL INTEREST RATES

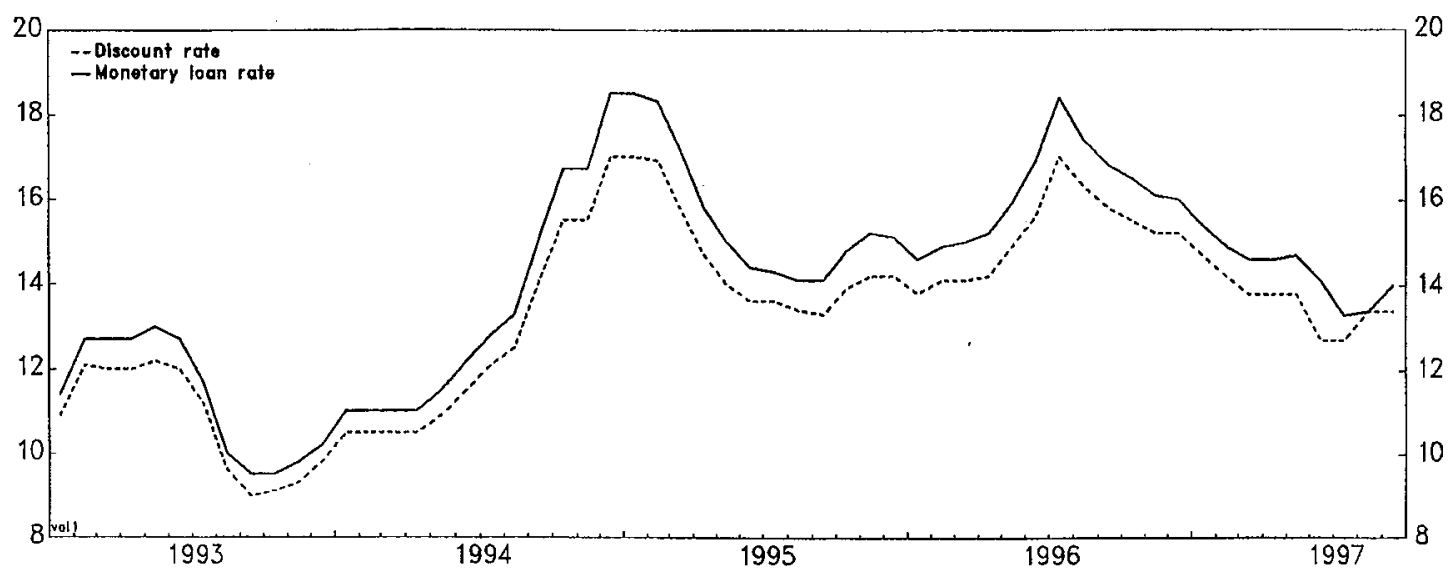

REAL DISCOUNT RATE (DEFLATED BY OVERALL CPI)

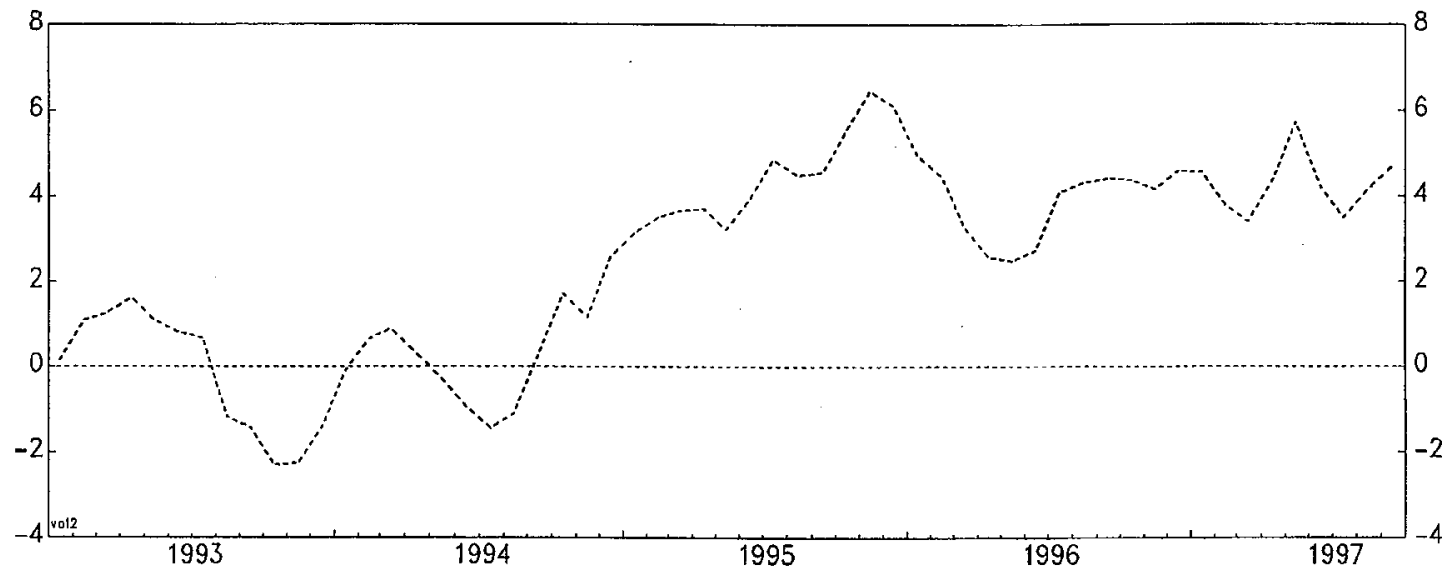

OUTPUT GROWTH AND INFLATION

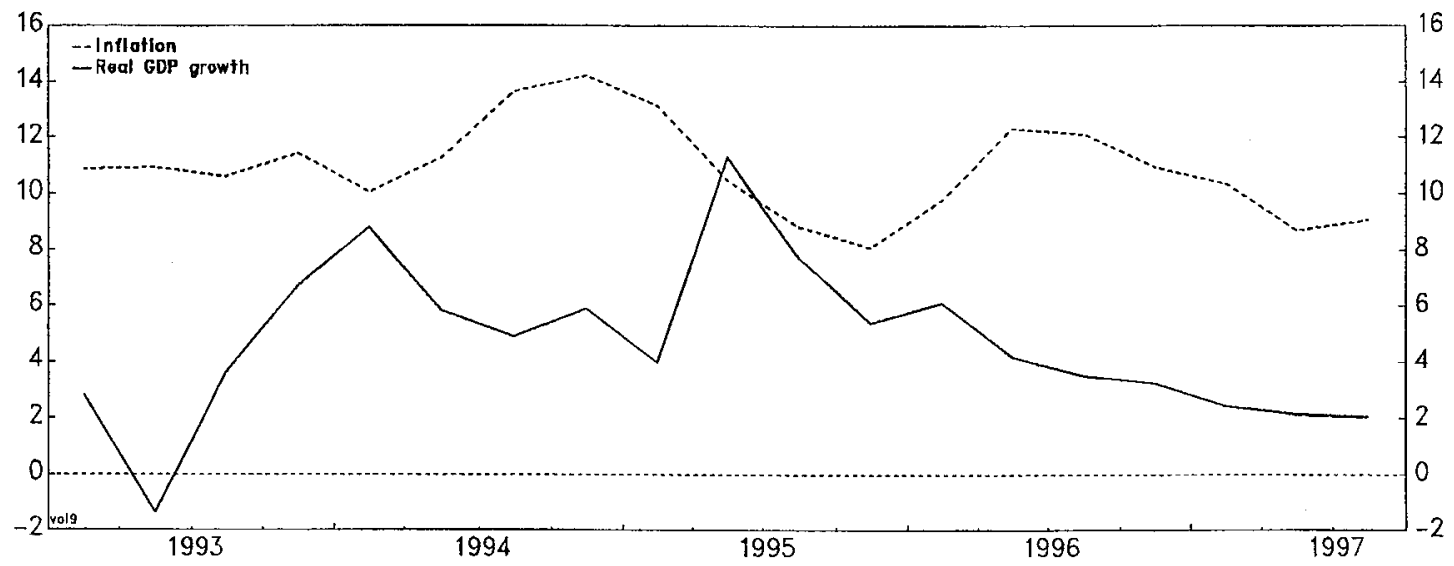

Sources: Central Bureau of Statistics; and Bonk of Israel. 


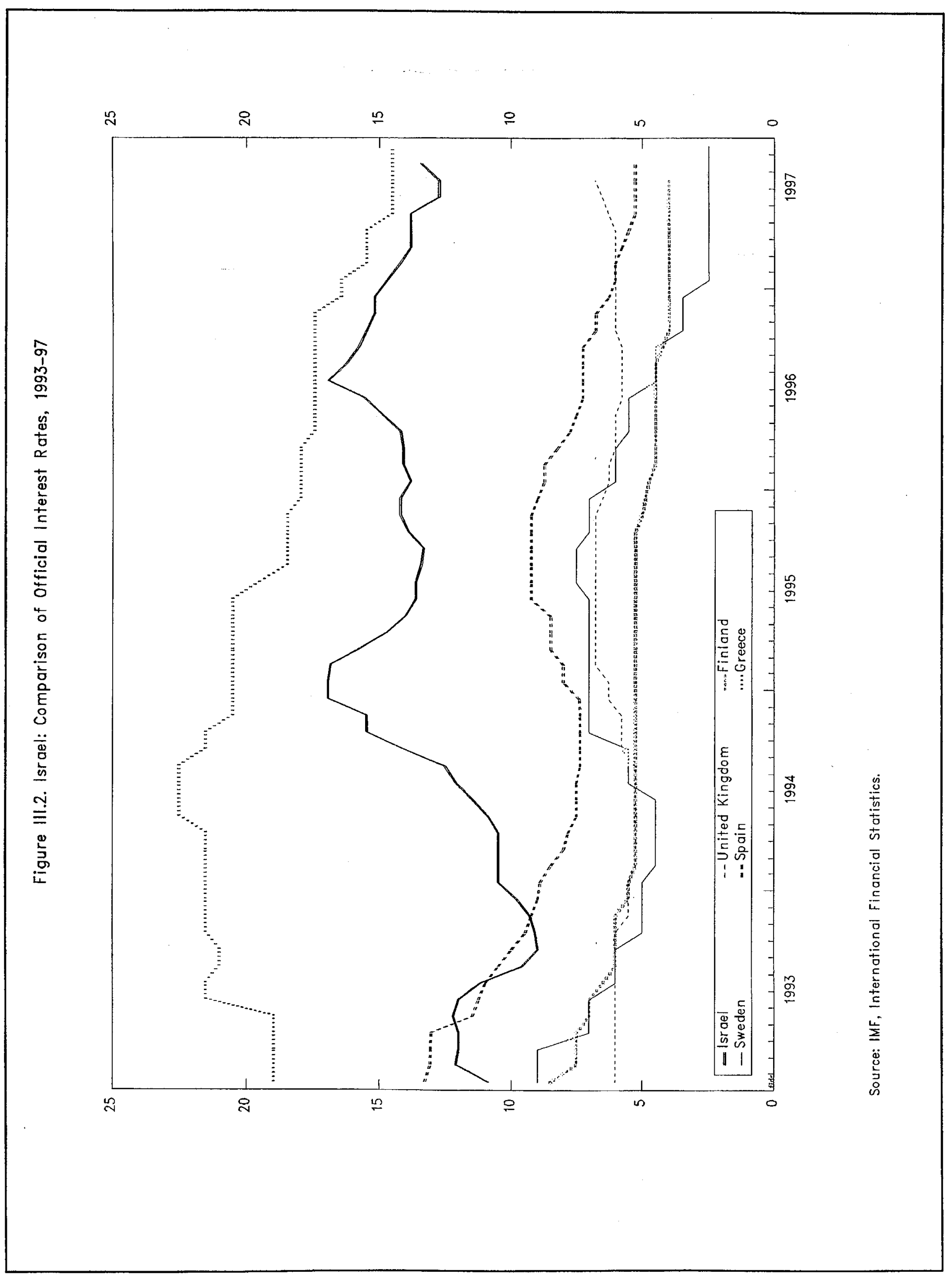


Figure III.3. Israel: Comparison of Official Interest Rates, 1993-97

(Period-to-period change)
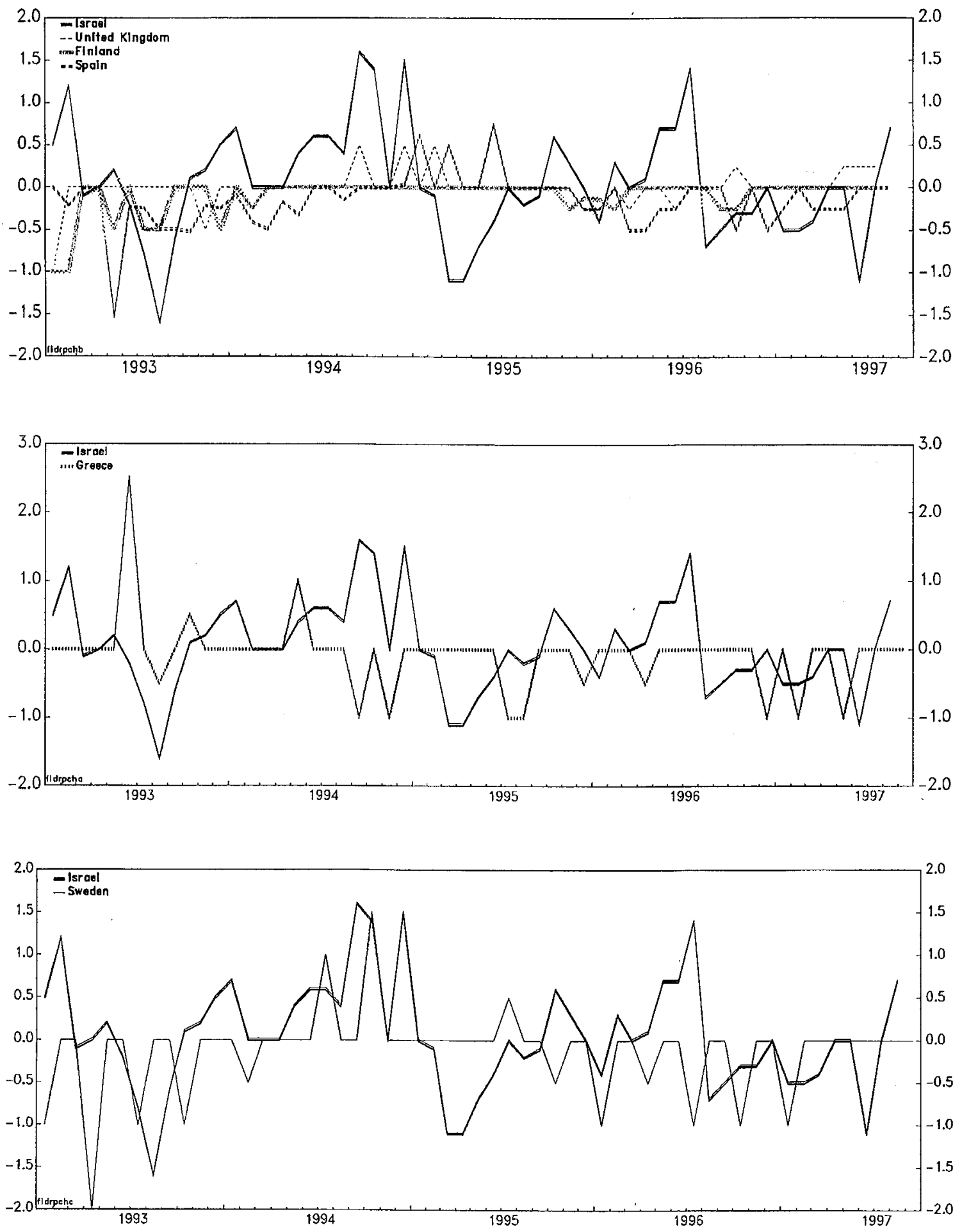

Source: IMF, International Financial Statistics. 
Figure III.4. Israel: Measures of Inflation, 1993-97

HEADLINE RATES

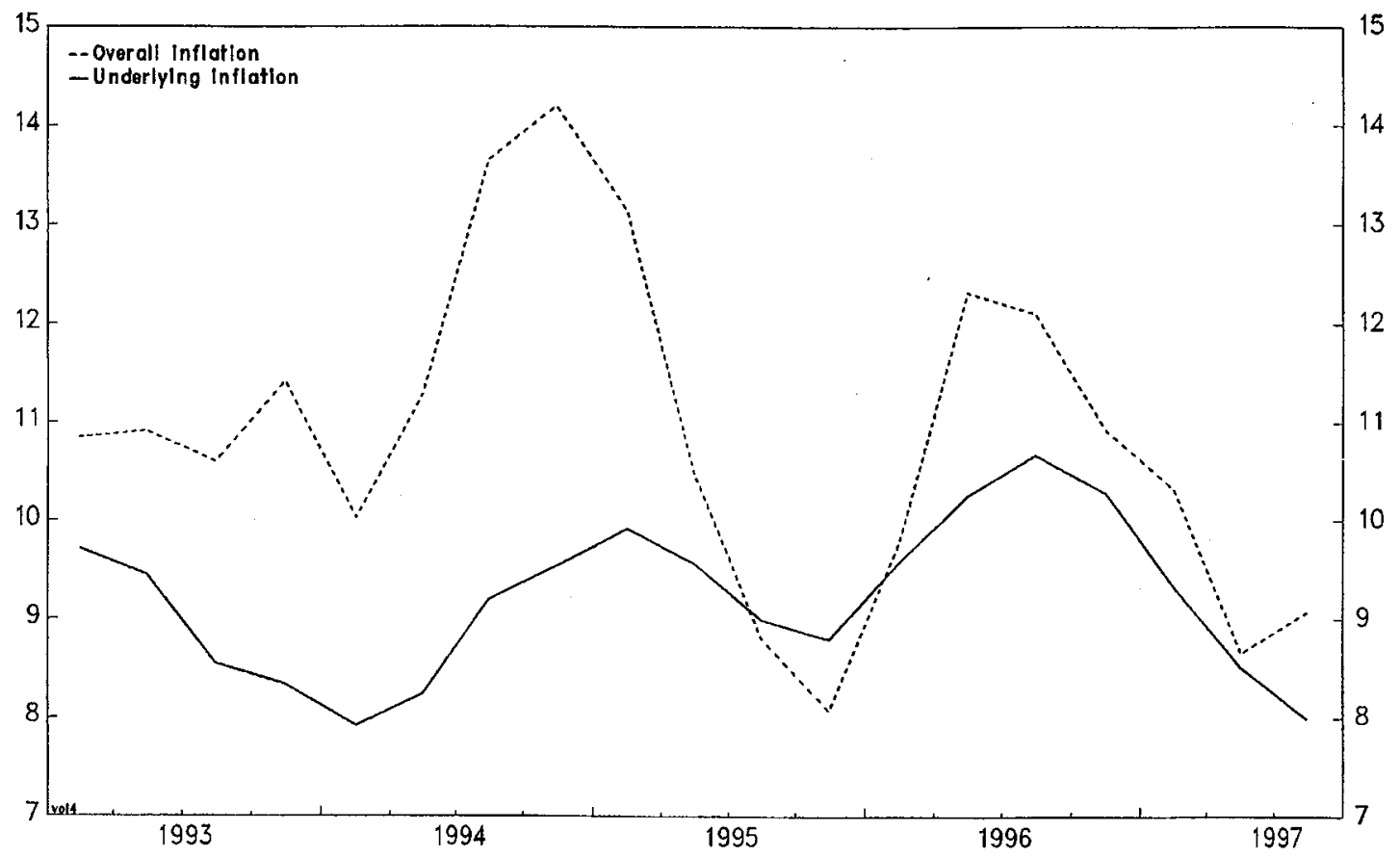

VOLATILE PRICES

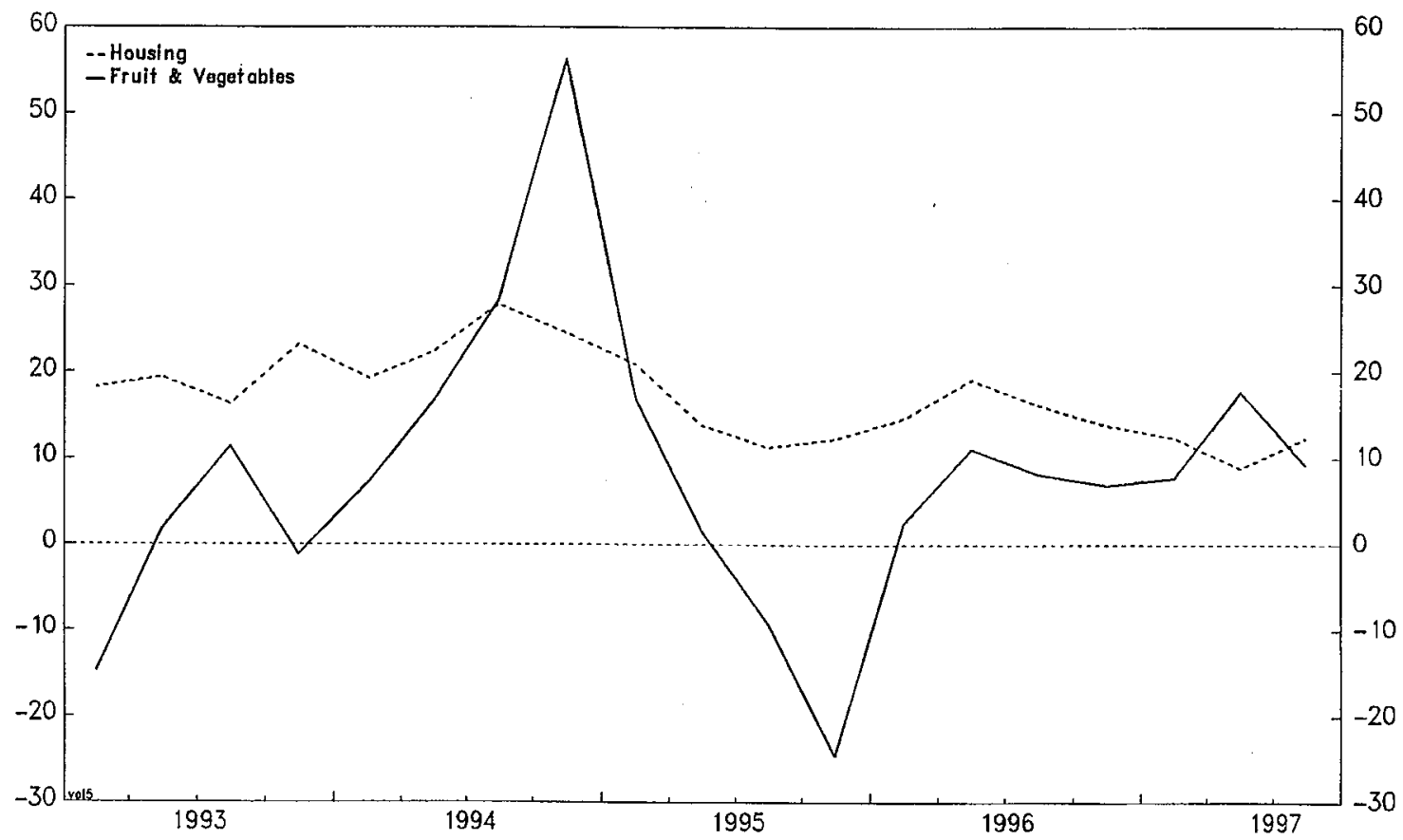

Sources: Central Bureau of Statistics; and Bank of Israel. 
Figure 11I.5. Israel: Measures of Inflation Expectations, 1993-97

DISCOUNT RATE LESS INFLATION EXPECTATIONS

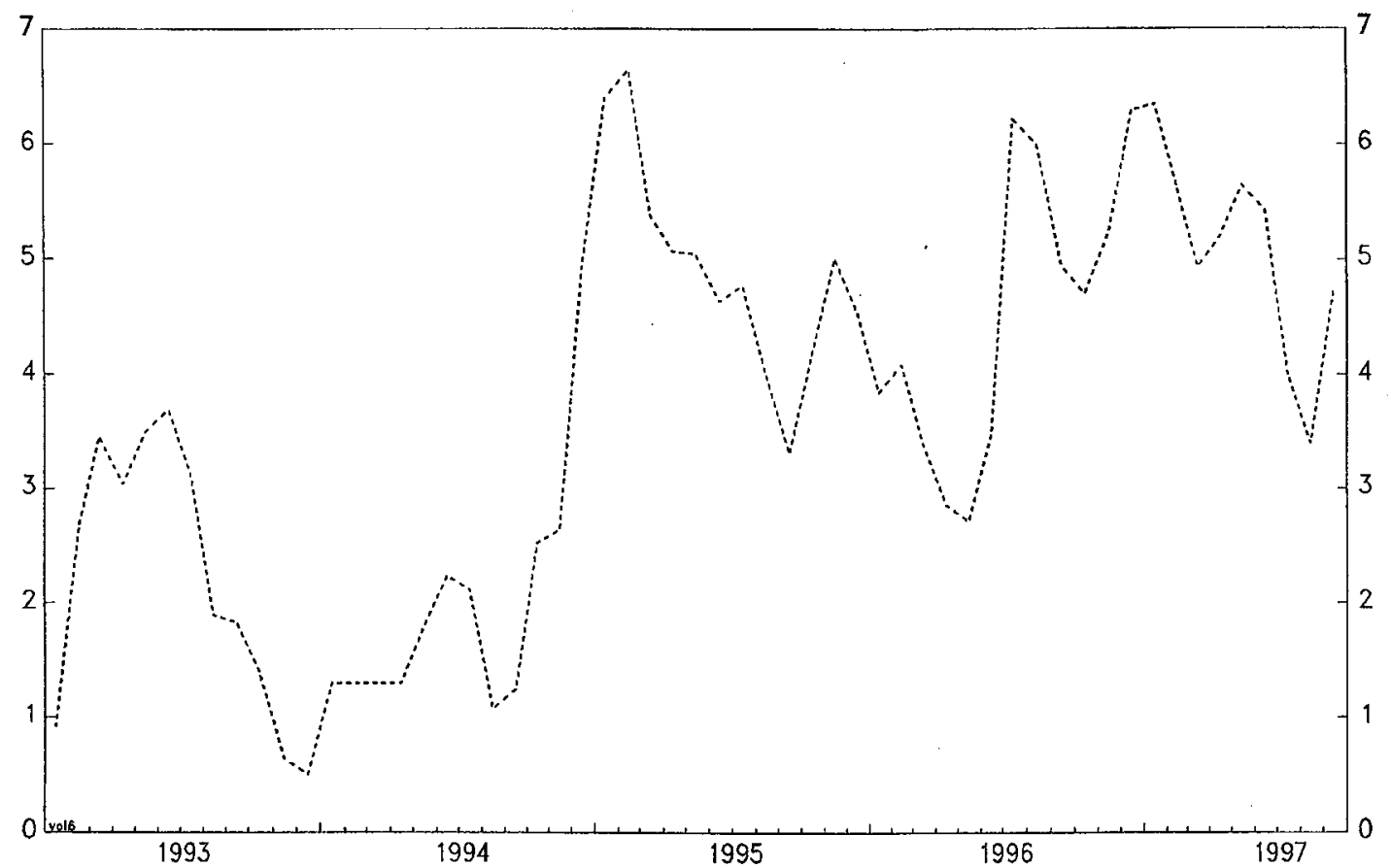

INFLATION EXPECTATIONS LESS INFLATION

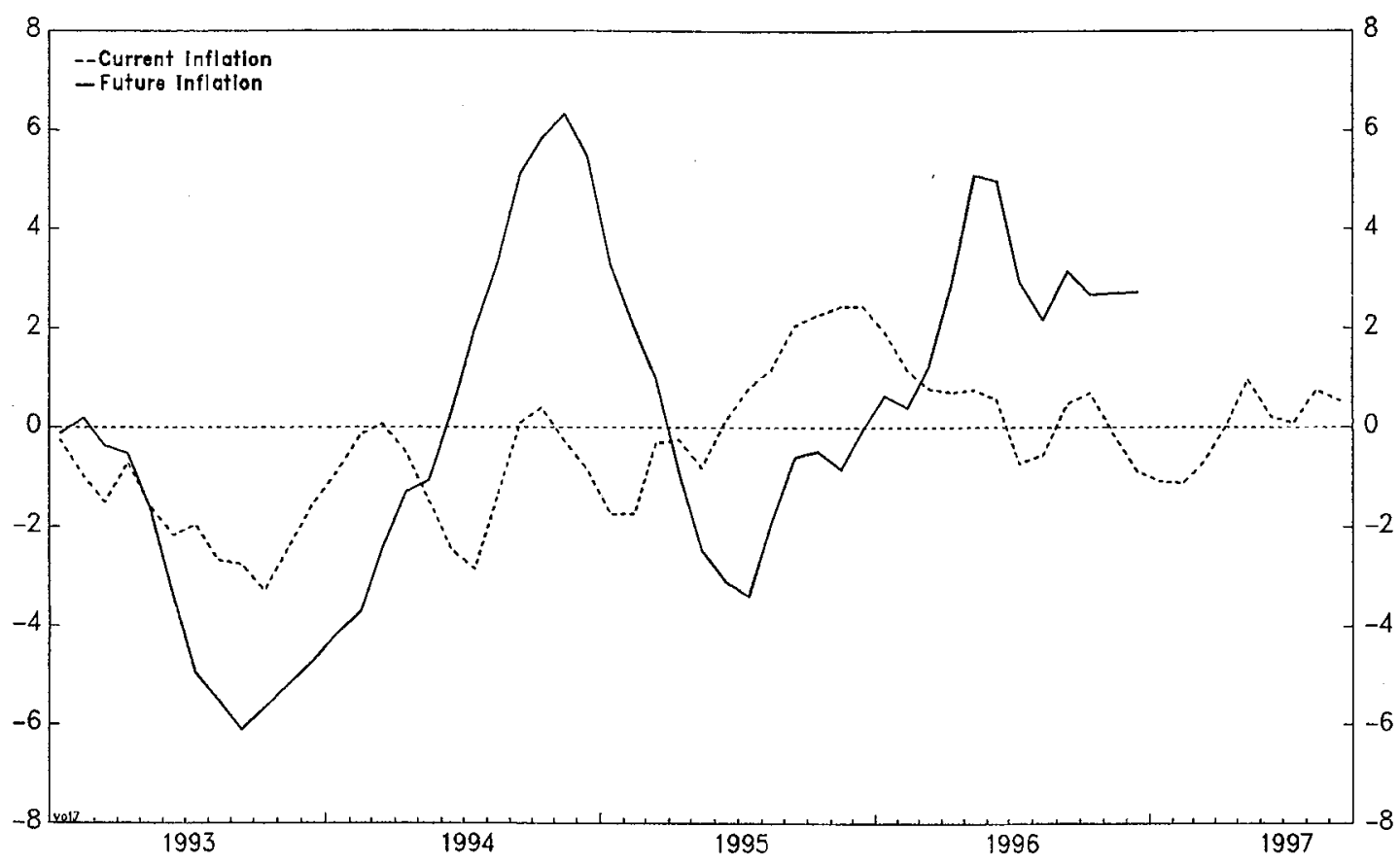

Sources: Central Bureau of Statistics; and Bank of Israel. 


\begin{tabular}{|c|c|c|c|c|c|c|c|c|}
\hline 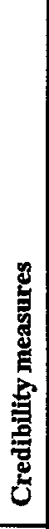 & 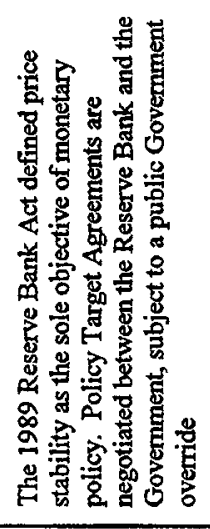 & 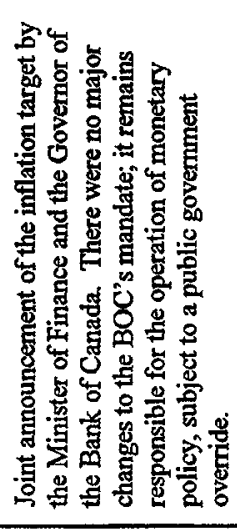 & 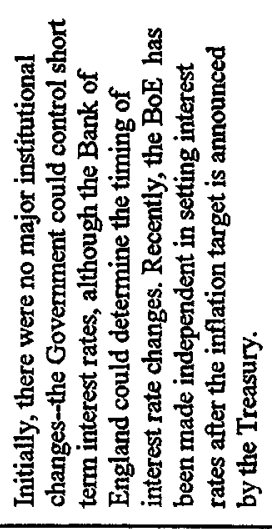 & 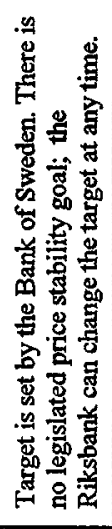 & 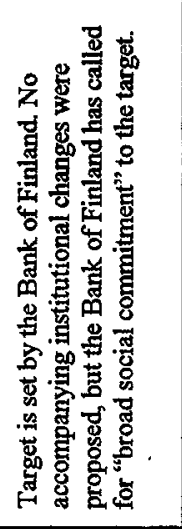 & 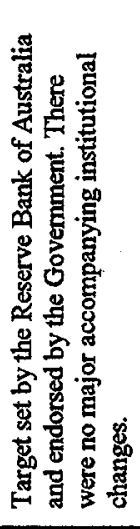 & 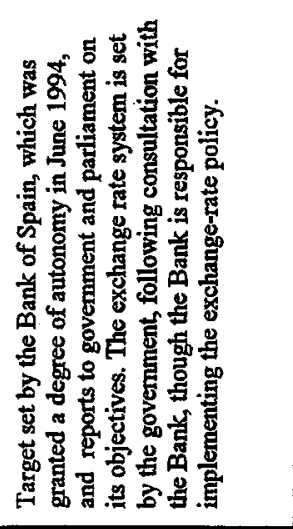 & 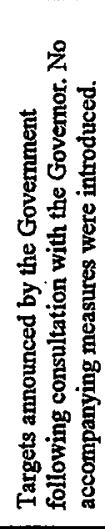 \\
\hline 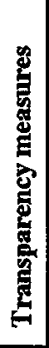 & 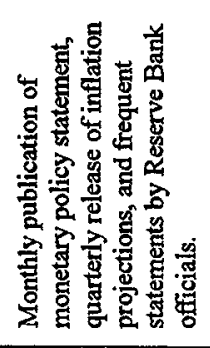 & 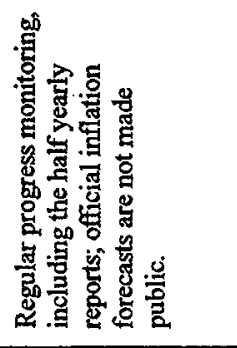 & 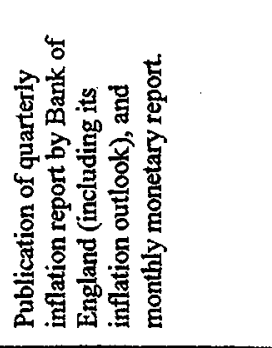 & 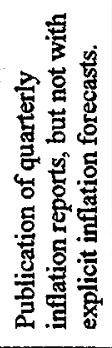 & 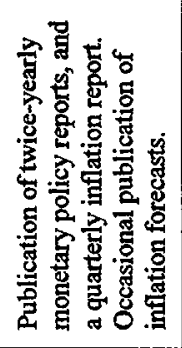 & 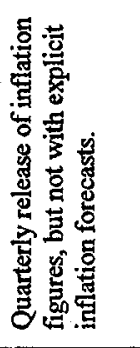 & 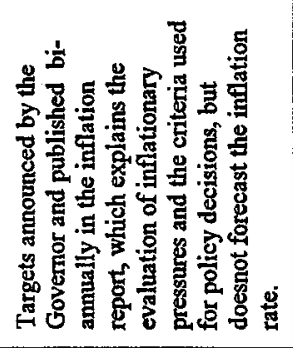 & 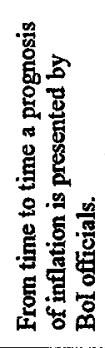 \\
\hline 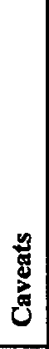 & 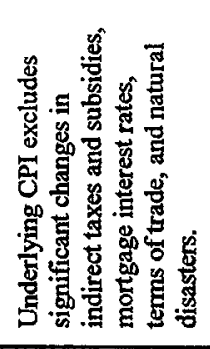 & 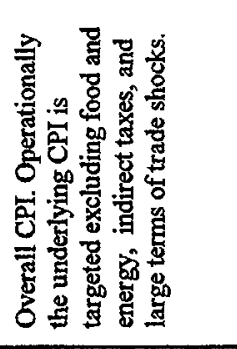 & 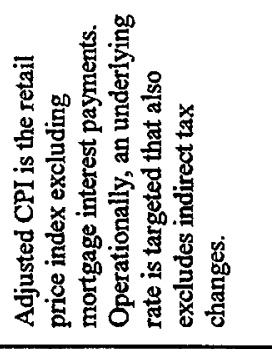 & 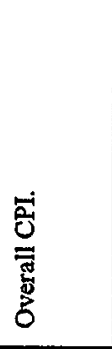 & 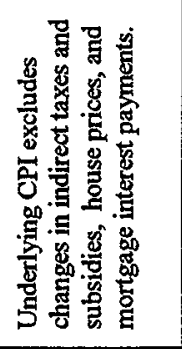 & 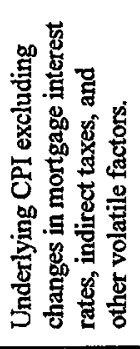 & 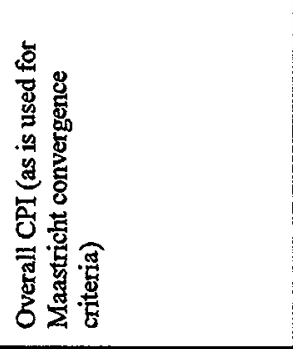 & 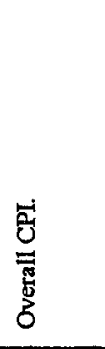 \\
\hline 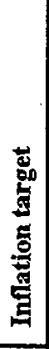 & 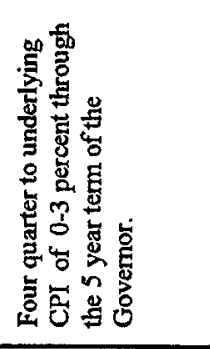 & 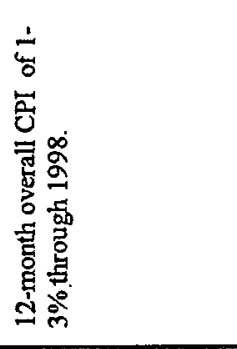 & 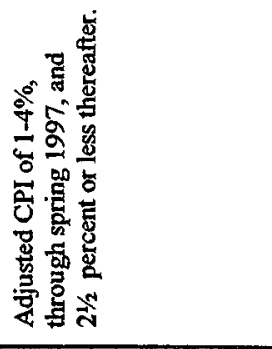 & 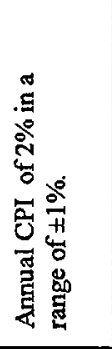 & 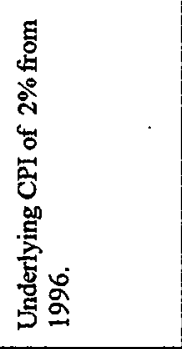 & 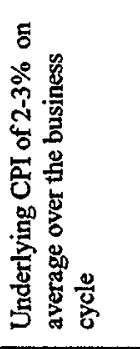 & 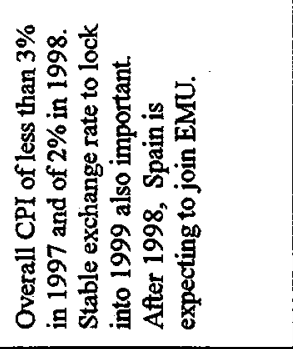 & 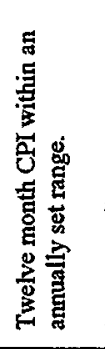 \\
\hline 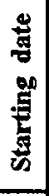 & 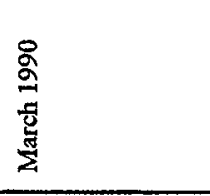 & 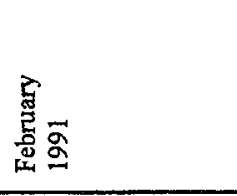 & $\begin{array}{l}\frac{N}{2} \\
\frac{8}{8} \\
\frac{8}{8}\end{array}$ & 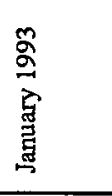 & 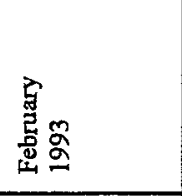 & 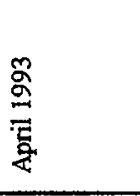 & 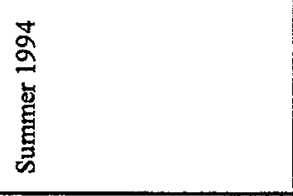 & 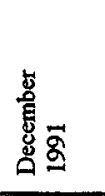 \\
\hline 롱 & 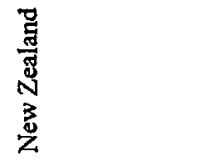 & $\begin{array}{l}\text { तु } \\
\text { స్ }\end{array}$ & 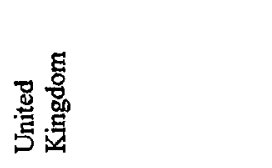 & 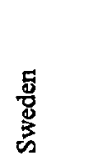 & 㞼 & 变 & 言 & $\underline{\underline{n}}$ \\
\hline
\end{tabular}




\section{References}

Bernanke, B.S., and M. Woodford (1997), "Inflation Forecasts and Monetary Policy," NBER Working Paper No. 6157, September.

Cote, A., J. Jacob, J. Nelmes, and M. Whittingham (1996), "Inflation Expectations and Real Return Bonds," Bank of Canada Review (Summer), 41-53.

Debelle, G., and S. Fischer (1994), "How Independent Should a Central Bank Be?" inJ. Fuhrer (ed.), Goals, Guidelines, and Constraints Facing Policymakers, Federal Reserve Bank of Boston Conference, Volume 38.

Fama, E.F. (1975), "Short-term Interest Rates as Predictors of Inflation," American Economic Review, 65(3), 269-82.

Frenkel, J. (1996), "Israel's Experience with Inflation," in Achieving Price Stability, Federal Reserve Bank of Kansas City.

Griffiths, M. (1995), "International Experience with Inflation Targeting: A Survey," International Monetary Fund, mimeo.

Holbrook, R.S. (1972), "Optimal Economic Policy and the Problem of Instrument Instability," American Economic Review, 62(1), 57-65.

Klein, D. (1997), "Transmission Channels of Monetary Policy in Israel," paper prepared for a conference on Transmission Mechanism of Monetary Policy at the BIS, January.

Liederman, L., and G. Bufman (1996), "Searching for Nominal Anchors in Shock-Prone Economies in the 1990s: Inflation Targets and Exchange Rate Bands," in R. Hausmann andH. Reisen (eds.), Securing Stability and Growth in Latin America (Paris: OECD and IDB).

Masson, P.R., M.A. Savastano, and S. Sharma (1997), "The Scope for Inflation Targeting in Developing Countries," International Monetary Fund WP/97/130, October.

Offenbacher, A. (1996), "How Inflation has Come Down," Central Banking Special Issue, 7(3), Winter.

Price, R. (1997), "The Rationale and Design of Inflation-Indexed Bonds," International Monetary Fund WP/97/12, January.

Sargent, T. and N. Wallace (1981), "Some Unpleasant Monetarist Arithmetic," Federal Reserve Bank of Minneapolis Quarterly Review, Fall. 
Sokoler, M. and others (1997), "Credibility Half-Won in a Continuous Battle: An Analysis of Inflation Targets and Monetary Policy in Israel," paper presented at the Conference of Inflation and Disinflation in Israel, Jerusalem, June 23.

Yariv, D. (1995), "Market Based Indicators of Inflationary Expectations as an Indicator for Monetary Policy: The Case of Israel," Bank of Israel, mimeo. 


\section{Corporate income tax (CIT)}

General nature: The CIT follows the classic system: profits are taxed at the corporate level and distributed dividends are taxed at the individual level (see withholding tax below). All companies, resident or nonresident for tax purposes, are subject to tax on Israeli-sourced income.

Notable special features: A comprehensive set of inflation adjustments is available. For resident companies, the adjustments generally involve a deduction from taxable income, the amount of which is linked to the shareholders' equity. These deductions are reduced, however, by assets that are considered inflationary-immune, e.g., fixed assets. For nonresident companies meeting certain criteria, an option to keep records for tax purposes in U.S. dollars is available.

Rate structure: The regular rate is 36 percent since 1996 (which has been reduced by 1 percent each year from 40 percent in 1992). The tax rate for income accrued outside of Israel and then received in Israel is 25 percent. Numerous special rates are available (see tax incentives below).

Revenue significance: 3.2 percent of GDP and 10.4 percent of total tax revenue in 1996.

\section{Personal income tax (PIT)}

General nature: All individuals, resident or nonresident for tax purposes, are subject to the PIT on Israel-source active and passive income. Deductions of national insurance contributions can be made against wage income for employees and against 52 percent of nonwage income for the self-employed as well as contributions to advanced training funds. Capped deductions are also allowed for charitable donations, shift labor, and residents living in certain geographic areas. Tax relief for interest on savings plans and for incomes from pensions and provident funds is provided. A system of tax credits based on points is in operation with a minimum of 2.25 credit points for each Israeli resident taxpayer with, inter alia, working women entitled to an additional 0.5 point, married persons with nonworking spouses an additional 1 point, working women with children under 18 an additional one point for each child, and recent immigrants an additional $1-3$ points for periods up to $3 \frac{1}{2}$ years. As of January 1997, each credit point was worth NIS 141 per month; the value of a credit point is adjusted once per year.

Notable special features: Fringe benefits provided by employers are comprehensively taxed, including an imputed value of usage of company cars.

Rate structure: In 1997, five periodic inflation-adjustable brackets of 10-20-30-45-50 percent. A minimum rate of between 25-35 percent applies to various types 
of passive income (i.e., nonwage or nonbusiness income), including dividends, interest, rental income, and capital gains; income from these sources is taxed at the marginal personal income tax rate thereafter (i.e., at 45 percent and 50 percent). The tax rate for income accrued abroad and remitted to Israel is 25 percent. Since 1995, citizens over 59 years pay a minimum tax on active and passive income of 10 percent.

Revenue significance: 10.8 percent of GDP and 35.0 percent of total tax revenue in 1996.

\section{Withholding tax}

General nature: Tax is withheld at source on a variety of incomes and payments, including wages, national insurance contributions, royalties and most investment incomes (e.g., interest and dividends). Withholding on investment incomes paid to individuals is generally final.

Rate structure: For dividends, rates are 25 percent (regular rate) and 15 percent (approved enterprises-see tax incentives below); for interest, rates are 35 percent (on interest from government and private bonds to residents and from residents' foreign currency bank accounts) and 25 percent (on interest from private bonds to nonresidents).

\section{Capital gains tax (CGT)}

General nature: The CGT is formally a part of the CIT or PIT, as the case may be. Under the CIT and PIT, resident companies and individuals are taxed on their world-wide gains; nonresident companies and individuals are taxed on gains from Israel-source assets. Gains from real estate are taxed under a separate Land Betterment Tax with broadly similar rules (see below).

Capital gains arising from the sale of securities listed on the Tel Aviv Stock Exchange and of securities in Israeli industrial companies and industrial holding companies listed on specified foreign stock exchanges are usually taxed only if the seller is a company or an individual who holds securities as part of the primary business. For other individuals (resident or nonresident), their gains are exempt from taxes. Capital gains accruing to dealers of securities are taxed as for regular income under the CIT. Gains from the sale of securities of unlisted companies are taxable as for individuals.

Rate structure: Nominal gains on assets acquired after 1960 are divided into real and inflationary parts. Real gains are taxable as regular income rates, while inflationary gains accrued until 1994 are taxable at 10 percent; nominal gains accrued after 1994 are tax exempt. Assets acquired before 1960 are taxed as follows: for assets acquired up to 1948, the final tax is 12 percent; for assets acquired between 1949-60, 1 percent is added to the 12 percent tax rate for each year after 1948, up to a total of 24 percent. Sales by individuals and mutual funds of foreign securities that are not traded on the Tel Aviv Stock Exchange are taxed at the flat rate of 35 percent. 


\section{Payroll taxes}

General nature: There are four main payroll categories: (a) national insurance (social security) contributions from both employers and employees to cover an array of benefits, such as old age pensions, disability benefits, family allowances, and unemployment benefits; (b) employer's tax (paid by public and nonprofit institutions only); (c) national health insurance premiums (effective from 1995) from all residents, in lieu of such payments on a private-billing basis; and (d) payroll taxes in lieu of value-added tax (VAT) paid by certain organizations (see VAT below).

Rate structure: As of January 1997, for category (a), resident employees pay either 4.93 percent or a reduced rate of 2.66 percent on active income (the reduced rate applies to the first 50 percent of the average wage) and on the share of husband's passive income that exceeds 50 percent of his total income; employers pay a flat amount of 4.93 percent of payroll. For the self-employed, the combined rates (also progressive) are 5.72 percent and 9.62 percent. For category (b), resident employees also pay either 4.93 percent or the reduced rate of 2.66 percent, though employers pay just 4 percent of payroll. The maximum taxable income subject to payroll taxes is four times the average wage (NIS 20,176 per month as of January 1, 1997; the nominal value of the ceiling is adjusted once per year and whenever the official cost of living is adjusted). All citizens are required to pay national insurance payroll taxes, regardless of whether they work (except married homeworkers who do not work outside of the home), or whether they reside abroad. Career soldiers, foreign workers in Israel, and workers from the territories are exempt. For category (c), the arrangements are similar as for those above. Only individuals contribute, at 4.8 percent and a reduced rate of 3.1 percent on the first 50 percent of the average wage.

Revenue significance: 7.2 percent of GDP; though not part of the general budget, they represent 18.0 percent of total (nonpayroll) tax revenue in 1996.

\section{Property-related taxes}

(1) Land Betterment Tax: levied on capital gains arising from the sale of real estate. The rate structure applying to the sale of real estate is the same as for the capital gains tax. Sale of one residential dwelling is exempt from land betterment tax once every four years, and the sale of two dwellings with a combined value of NIS 1.2 million (adjusted annually for changes in the CPI) is exempt once per taxpayer's lifetime (and is subject to a variety of conditions).

(2) Real Estate Purchase Tax: levied on the purchase of all residential apartments, buildings and vacant land. Rates are 3.5 percent on business buildings, 5 percent on vacant land, $0.5-4.5$ percent on residential apartments (rising with value, which in general is adjusted quarterly on the rate of increase in the housing price index), and either 0.5 percent or 5 percent on farms. Various preferences qualify for the 0.5 percent rate for real estate holdings. 
(3) Property Tax: levied annually on the value of vacant urban land. The rate is 2.5 percent, but is taxed at 1.2 percent if the land is part of a business's inventory. Government, public institutions, and United Nations agencies are exempt. Fruit orchards qualify for a deduction of NIS 60,200 per dunam for property tax purposes.

Revenue significance: Total property tax was 1.2 percent of GDP and 4 percent of total tax revenue in 1996.

VAT

General nature: Standard credit-invoice based.

Notable special features: The base is broad with exemptions limited to certain sales of assets. Major zero-rated items are exports, unprocessed fruits and vegetables, and tourism services.

Rate structure: 17 percent (apart from the zero rate). Financial institutions pay 17 percent on their payroll and profits (deductible against taxable income under the CIT but not creditable against other VAT payments), and nonprofit institutions pay 8 percent on their payroll (not creditable against other VAT payments).

Revenue significance: 10.7 percent of GDP and 34.6 percent of total tax revenue in 1996.

\section{Purchase tax}

General nature: A purchase tax is imposed on the wholesale price of selected final consumer goods (imported or locally produced), most notably motor vehicles and a limited number of raw materials and intermediate goods.

Rate structure: Between 5 percent to 95 percent.

Revenue significance: 2.5 percent of GDP and 8.1 percent of total tax revenue in 1996.

\section{Excise and stamp duties}

General nature: Excises are imposed on tobacco, cement and fuel. Stamp duties are imposed on most legal documents, though several government contracts are exempt.

Rate structure: Excise duty rates vary. On cigarettes, the rate is 55 percent of the consumer price excluding VAT plus NIS 0.875 per pack. On fuel, the rate varies between NIS $1.68-1.75$ per liter for petroleum, and NIS 0.06 per liter for diesel and kerosene (adjusted quarterly on the rate of increase in the CPI). Stamp duty rates vary between $0.4-3.0$ percent.

Revenue significance: 1.9 percent of GDP and 6.1 percent of total tax revenue in 1996. 


\section{Customs duties}

General nature: Most imports to Israel are exempt from customs and duties, and all quotas have been converted into tariffs. For non-food imports which are not exempt, as of September 1996 customs duties generally varied between 8 percent and 20 percent. For sensitive products (textiles and lumber) the rates are 55 percent and 38.7 percent. Imports of lumber, footwear, fertilizers, sheet metal, ceramic implements, and electric motors will attain their final rate of 8-12 percent in September 1998. The textile industry will do so in September 2000. In general, imports of ships, aircraft, diamonds, and inputs and intermediate goods are exempt. Processed foods are charged customs duties of between 30-100 percent.

All goods imported under the Free-Trade Agreements with the United States, European Union and EFTA (European Free Trade Area) are duty free. Since 1997 there is a trade agreement between Israel and Canada, the Czech Republic, Slovakia and Turkey, which will reduce tariffs on industrial products to zero by the year 2000 .

Rate structure: See description above.

Revenue significance: 0.3 percent of GDP and 1 percent of total tax revenue in 1996.

\section{Local taxes}

General nature: Local taxes comprise primarily those on property (arnona) and a range of user fees and water charges.

\section{Tax incentives}

General nature: Most tax incentives are granted under the Encouragement of Capital Investment Law (1959, as amended), Encouragement of Industry (Taxes) Law (1969, as amended), Encouragement of Industry (Taxes) Law 1969, as amended), Encouragement of Capital Investments in Agriculture Law (1980, as amended), and Encouragement of Industrial Research and Development Law (1984, as amended) to: (a) approved enterprises (projects) without sectoral restrictions but mostly in manufacturing and tourism, with varying benefits depending on location (i.e., whether then are in or outside national priority zones A and B); (b) approved agricultural projects; (c) income from properties which form part of an approved enterprise enjoying the tax benefits; (d) industrial companies with at least 90 percent of gross revenue derived from productive activities; (e) companies with at least 25 percent of foreign investment that own approved enterprises; and (f) approved international trading companies (excluding importing to and exporting from Israel).

There are, in addition, the Free Port Zone Law (1969), establishing Kishon Port (Haifa), Port of Ashdod, and Port of Eilat as free ports; the Eilat Free Trade Zone Law (1985), establishing the city of Eilat and its surrounding one kilometer area as a free trade zone; and the Free 
Export Processing Zone Law (1994), under which one such zone is being established near Beer Sheva.

Approved enterprise status is granted by the Investment Center at the Ministry of Trade and Industry, and generally required a minimum of 30 percent in paid-up capital by the investor(s).

Forms of incentives: The system of incentives is complex, with varying incentives subject to differing requirements. In general, it has the following structure.

(1) Investment (cash) grants: provided as a percentage of investment in net fixed assets. The grant is deducted from the value of fixed assets for depreciation and capital gains purposes. Grants range from 5 percent to 24 percent (in 1994), depending on nature and location of the approved enterprise. Approved enterprises may also receive an accelerated depreciation schedule.

(2) Reduced CIT rate: provided on taxable income of an approved enterprise (including agricultural projects) with a reduced CIT rate of 25 percent for 7 years. The withholding tax on dividends paid by an approved enterprise is 15 percent for 19 years. The benefits are enhanced if the approved enterprise has substantial foreign ownership: a reduced rate of 25 percent applies for 10 years if the percentage of foreign ownership is $25-49$ percent; the applicable CIT rate further decreases (to a low of 10 percent) with increases in foreign ownership (to 90 percent or more). Dividends paid by approved enterprises with a minimum of 25 percent foreign ownership are subject to a withholding tax of 15 percent with no time limit. Rate incentives on income from approved assets are similar to those applicable to approved enterprises described above.

(3) Tax holidays (alternate track): instead of receiving investment grants, approved enterprises can opt for a CIT holiday of 2-10 years, depending on location (if the holiday period is shorter than the applicable period of reduced CIT rate, the benefits of the latter commence upon the expiration of the holiday). Withholding tax on dividends is applicable as if the enterprises had not chosen the holiday option. Approved international trading companies can enjoy a CIT holiday of 10 years.

(4) Industrial incentives: such companies can deduct from taxable income various capital and R\&D expenditures.

(5) Free port zones: enterprises established in a free port enjoy a CIT holiday (except on real capital gains, which are taxed under the regular system) of 7 years, after which a 25 percent rate applies without time limit. Dividends are taxed at 15 percent, also without time limit. Under the Eilat free trade zone, residents are entitled to a tax credit of 10 percent of their taxable income (but no more than the total tax otherwise payable) under the PIT. Employers are allowed to retain 20 percent of wages from payroll taxes withheld from employees (but no more than the actual taxes withheld). The VAT is also exempted. Under the free export 
processing zone, there is a CIT holiday of 20 years, but dividends and capital gains are taxed at 15 percent. Imports and intra-zone sales are free from indirect taxes.

Revenue significance: Total investment grants and subsidies, which represent explicit outlays, amounted to about 3.2 percent of GDP in 1996. Total tax expenditures (inclusive of all direct and indirect taxes), which represent revenue forgone, have been estimated at about 5.2 percent of GDP for 1996. 
ISRAEL: RECENT DEVELOPMENTS IN THE EXCHANGE AND TRADE SYSTEM

A full description of the exchange control system (and changes up to February 1997) is available from the Annual Report on Exchange Arrangements and Exchange Restrictions, 1997. This appendix updates developments from February 1997 to January 1, 1998.

\section{Exchange arrangement}

In June 1997, the shekel trading band was widened: the upper band was raised to 21 percent with an unchanged slope of 6 percent, and the slope of the lower band was reduced to 4 percent.

\section{Exchange controls}

The following changes were announced in July 1997 :

- The limit on financial investment abroad by provident funds was raised from 2 percent to 5 percent of their assets.

- The limit on financial investment abroad by mutual funds was raised from 10 percent to 50 percent of their assets. ${ }^{42}$

- The limit on holdings of foreign securities and foreign currency abroad by Israeli companies was raised from 5 percent of their turnover or 10 percent of their equity capital, whichever was higher, to 15 percent of their turnover or 25 percent of their equity capital, whichever was higher.

- Institutional investors were permitted to engage in foreign securities transactions directly with a broker abroad.

- All restrictions on futures transactions abroad by Israeli residents were eliminated.

- The annual limit on foreign currency remittances abroad by Israeli residents as gifts or support payments was raised from $\$ 2,000$ to $\$ 10,000$.

- The monthly limit on foreign currency student support payments abroad was raised from $\$ 1,000$ to $\$ 2,500$.

\footnotetext{
${ }^{42}$ Prior to that, only mutual funds specializing in investment abroad could invest up to 50 percent of their assets abroad. Nonresident mutual funds are permitted to invest up to 75 percent of their assets in foreign financial assets.
} 
- Recipients of restitutions payments from Germany or of pensions from abroad were permitted to deposit these payments in bank accounts abroad.

In August 1997, the following liberalization measures were announced as part of the budgetary and structural reform decisions for 1998 :

- Israeli residents will be permitted to purchase foreign currency with local currency and to deposit it in foreign currency deposits in Israeli banks.

- Israeli residents will be permitted to transfer money between foreign currency deposits.

- All restrictions on mutual funds' investments in foreign securities will be abolished.

- The limit on holdings of foreign securities and foreign currency abroad by Israeli companies will be abolished.

- Israeli residents and nonresidents traveling abroad will be permitted to purchase $\$ 1,000$ on leaving the country without having to produce documents or personal identification.

- Israeli residents living abroad will be permitted to open bank accounts there.

- Nonresidents will be permitted to convert local currency deposited in the Bank of Israel into foreign currency.

- Israeli banks will be permitted to purchase local currency from banks abroad against foreign currency.

The first four of the above measures went into effect on January 1, 1998. Also, at that time, restrictions on local or foreign currency derivatives transactions by Israeli residents were lifted. 
Table A1. Israel: GDP by Expenditure Components in Current Prices, 1992-97

\begin{tabular}{|c|c|c|c|c|c|c|}
\hline & 1992 & 1993 & 1994 & 1995 & 1996 & 1997 \\
\hline & \multicolumn{6}{|c|}{ (In millions of new sheqalim; current prices) } \\
\hline Consumption & 143,211 & 168,995 & 204,558 & 239,526 & 278,605 & 229,850 \\
\hline Private & 98,079 & 116,563 & 142,768 & 161,831 & 187,831 & 154,759 \\
\hline Public & 45,132 & 52,432 & 61,790 & 77,695 & 90,774 & 75,091 \\
\hline Gross domestic capital formation & 39,922 & 45,929 & 53,085 & 64,801 & 73,181 & 53,503 \\
\hline Fixed capital formation & 38,086 & 42,484 & 52,023 & 61,393 & 70,634 & 53,045 \\
\hline Increase in stocks & 1,836 & 3,445 & 1,062 & 3,408 & 2,547 & 458 \\
\hline Total domestic demand & 183,133 & 214,924 & 257,643 & 304,328 & 351,786 & 283,353 \\
\hline Exports of goods and nonfactor services & 49,351 & 60,610 & 73,292 & 82,919 & 93,660 & 79,223 \\
\hline Imports of goods and nonfactor services & 71,714 & 90,616 & 107,750 & 126,074 & 141,634 & 112,231 \\
\hline Foreign balance & $-22,363$ & $-30,006$ & $-34,458$ & $-43,155$ & $-47,974$ & $-33,008$ \\
\hline \multirow[t]{2}{*}{ GDP } & 160,770 & 184,918 & 223,185 & 261,173 & 303,812 & 250,345 \\
\hline & \multicolumn{6}{|c|}{ (In percent of GDP; current prices) } \\
\hline Consumption & 89.1 & 91.4 & 91.7 & 91.7 & 91.7 & 91.8 \\
\hline Private & 61.0 & 63.0 & 64.0 & 62.0 & 61.8 & 61.8 \\
\hline Public & 28.1 & 28.4 & 27.7 & 29.7 & 29.9 & 30.0 \\
\hline Gross domestic capital formation & 24.8 & 24.8 & 23.8 & 24.8 & 24.1 & 21.4 \\
\hline Fixed capital formation & 23.7 & 23.0 & 23.3 & 23.5 & 23.2 & 21.2 \\
\hline Increase in stocks & 1.1 & 1.9 & 0.5 & 1.3 & 0.8 & 0.2 \\
\hline Total domestic demand & 113.9 & 116.2 & 115.4 & 116.5 & 115.8 & 113.2 \\
\hline Exports of goods and nonfactor services & 30.7 & 32.8 & 32.8 & 31.7 & 30.8 & 31.6 \\
\hline Imports of goods and nonfactor services & 44.6 & 49.0 & 48.3 & 48.3 & 46.6 & 44.8 \\
\hline Foreign balance & -13.9 & -16.2 & -15.4 & -16.5 & -15.8 & -13.2 \\
\hline GDP & 100.0 & 100.0 & 100.0 & 100.0 & 100.0 & 100.0 \\
\hline
\end{tabular}

Sources: Central Bureau of Statistics, Monthly Bulletin of Statistics and 1997 Statistical Abstract of Israel. 
Table A2. Israel: GDP by Expenditure Components in Constant Prices, 1992-97 1/

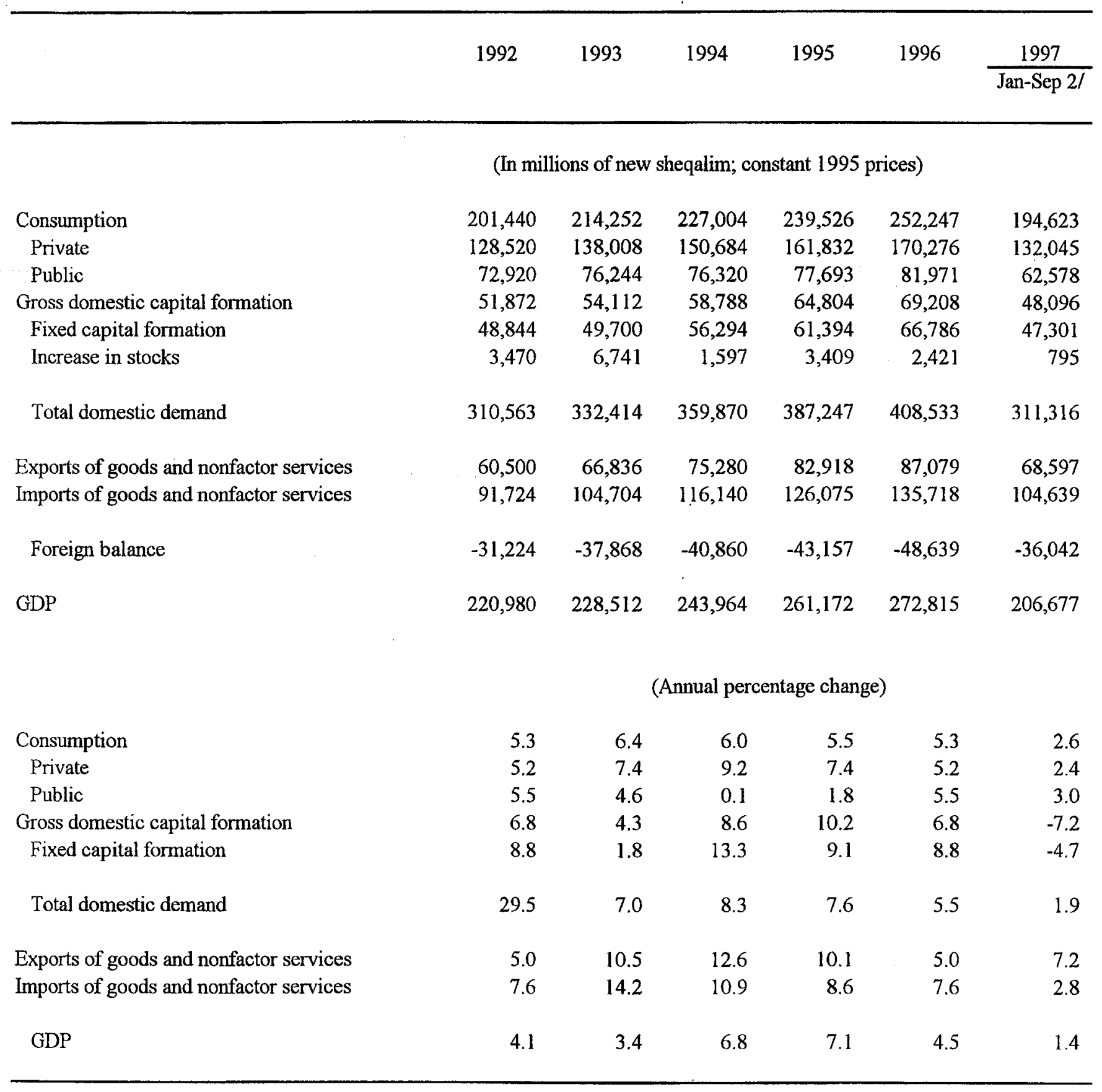

Sources: Central Bureau of Statistics, Monthly Bulletin of Statistics and 1997 Statistical Abstract of Israel.

1/Estimates in 1995 prices derived by chaining each categories growth rate computed at different base year prices; hence totals do not reflect the sum of their components.

2/ Percentage change refers to same period in 1996. 
Table A3. Israel: Investment, 1992-96 1/

\begin{tabular}{|c|c|c|c|c|c|c|}
\hline & \multirow{2}{*}{$\begin{array}{c}\begin{array}{c}\text { In millions of } \\
\text { new sheqalim }\end{array} \\
1996\end{array}$} & \multicolumn{5}{|c|}{ Percentage change at constant prices } \\
\hline & & 1992 & 1993 & 1994 & 1995 & 1996 \\
\hline Gross domestic capital formation & 73,181 & 6.6 & 4.3 & 8.6 & 10.2 & 6.8 \\
\hline Gross fixed capital formation & 70,634 & 6.7 & 1.8 & 13.3 & 9.1 & 8.8 \\
\hline Machinery, transport, and other equipment & 30,802 & 5.9 & 11.9 & 22.5 & 0.5 & 11.2 \\
\hline Land transport equipment & 6,941 & 22.8 & 5.9 & 19.1 & -8.3 & 20.2 \\
\hline Other machinery and equipment & 23,107 & 3.5 & 14.1 & 19.9 & 4.2 & 9.5 \\
\hline Ships and aircraft & 755 & -42.6 & 0.9 & 184.7 & -20.5 & -9.3 \\
\hline Construction & 39,832 & $\cdot 7.2$ & -5.6 & 5.3 & 17.6 & 6.9 \\
\hline Residential & 22,145 & 0.0 & -23.5 & 4.0 & 21.7 & 11.8 \\
\hline Private & 17,027 & 9.9 & 11.8 & 15.6 & 16.7 & 6.9 \\
\hline Public & 5,118 & -8.7 & -60.7 & -30.9 & 47.3 & 31.5 \\
\hline Nonresidential & 17,687 & 24.0 & 27.7 & 6.8 & 13.2 & 1.3 \\
\hline
\end{tabular}

Sources: Central Bureau of Statistics, Monthly Bulletin of Statistics and 1997 Statistical Abstract of Israel; and data provided by the Bank of Israel. 
Table A4. Israel: Consumption, 1992-96 1/

\begin{tabular}{|c|c|c|c|c|c|c|}
\hline & \multirow{2}{*}{$\begin{array}{l}\begin{array}{l}\text { In millions of } \\
\text { new sheqalim }\end{array} \\
1996\end{array}$} & \multicolumn{5}{|c|}{ Percentage change at constant prices } \\
\hline & & 1992 & 1993 & 1994 & 1995 & 1996 \\
\hline Private consumption & 187,831 & 7.8 & 7.4 & 9.2 & 7.4 & 5.2 \\
\hline \multicolumn{7}{|l|}{ Consumption by Israeli households } \\
\hline Household consumption in the domestic market & 184,182 & 9.5 & 6.9 & 8.2 & 7.5 & 4.6 \\
\hline Food, beverages, and tobacco & 40,983 & 4.1 & 7.5 & 8.6 & 6.5 & 4.8 \\
\hline Fuel and electricity & 7,747 & 18.1 & 5.5 & 6.8 & 6.5 & 5.8 \\
\hline Clothing, footwear, and personal effects & 11,064 & 14.4 & 19.0 & 15.1 & 8.9 & 0.8 \\
\hline Other goods & 10,062 & 12.5 & 14.3 & 8.1 & 9.2 & 5.0 \\
\hline Durable goods & 21,223 & 24.6 & 0.5 & 11.1 & 15.9 & 5.5 \\
\hline \multicolumn{7}{|l|}{ Of which } \\
\hline Passenger cars & 7,512 & 47.8 & -13.9 & 11.1 & 8.7 & 5.2 \\
\hline Housing & 42,437 & 5.2 & 4.5 & 3.3 & 3.0 & 3.7 \\
\hline Other services & 50,666 & 9.9 & 7.9 & 9.9 & 8.2 & 5.5 \\
\hline Plus: Consumption by Israelis abroad & 8,995 & 0.4 & 14.0 & 22.9 & 9.8 & 8.6 \\
\hline Less: Consumption by nonresidents & 9,709 & 49.1 & 7.9 & 9.0 & 16.3 & -3.8 \\
\hline Consumption by nonprofit institutions & 4,362 & 2.8 & 6.1 & 7.6 & 3.9 & 1.6 \\
\hline Public consumption (excluding net defense imports) & 84,459 & 3.0 & 0.6 & 5.3 & 2.1 & 3.0 \\
\hline Civilian & 60,476 & 4.7 & 4.3 & 6.9 & 4.0 & 3.8 \\
\hline Compensation of employees & 38,762 & 2.4 & 2.5 & 5.6 & 3.3 & 2.8 \\
\hline Indirect taxes on salaries & 3,064 & 1.2 & 3.1 & 5.6 & 3.3 & 3.2 \\
\hline Consumption of fixed capital & 3,861 & 3.4 & 3.8 & 4.1 & 4.0 & 3.0 \\
\hline Other current purchases & 14,789 & 14.2 & 10.3 & 11.9 & 5.9 & 6.6 \\
\hline Domestic defense & 23,983 & 0.0 & -6.2 & 2.0 & -2.0 & 1.1 \\
\hline Compensation of employees & 12,749 & -2.3 & -1.1 & 0.0 & -0.8 & -1.4 \\
\hline Indirect taxes on salaries & 631 & -1.2 & 1.2 & -0.6 & 0.0 & -1.1 \\
\hline Other current purchases & 10,603 & 2.2 & -11.3 & 4.1 & -3.3 & 4.4 \\
\hline \multicolumn{7}{|l|}{ Memorandum items: } \\
\hline Net defense imports & 6,316 & -23.6 & 52.7 & -31.4 & -13.3 & 18.2 \\
\hline Defense imports & 6,948 & -24.9 & 41.4 & -29.1 & -11.3 & 17.0 \\
\hline Less: Sales & 632 & -32.6 & -34.9 & 7.4 & 9.0 & 7.3 \\
\hline Public consumption including net defense imports & 90,775 & -0.3 & 5.4 & 0.3 & 0.6 & 3.9 \\
\hline
\end{tabular}

Sources: Central Bureau of Statistics, Monthly Bulletin of Statistics and 1997 Statistical Abstract of Israel; and data provided by the Bank of Israel. 
Table A5. Israel: Gross Private Income and Savings, 1992-96

\begin{tabular}{|c|c|c|c|c|c|}
\hline & 1992 & 1993 & 1994 & 1995 & 1996 \\
\hline & \multicolumn{5}{|c|}{ (In millions of new sheqalim; at current prices) } \\
\hline GNP at market prices & 158,617 & 183,832 & 220,787 & 257,246 & 300,003 \\
\hline Plus: & 4,131 & 4,302 & 4,862 & 4,446 & 4,484 \\
\hline Subsidies on domestic production & 3,594 & 3,831 & 4,442 & 4,082 & 4,159 \\
\hline Subsidies on government loans & 537 & 471 & 420 & 364 & 325 \\
\hline \multicolumn{6}{|l|}{ Less: } \\
\hline Indirect taxes on domestic production & 24,033 & 26,365 & 31,055 & 36,119 & 42,985 \\
\hline GNP at factor cost & 138,715 & 161,769 & 194,594 & 225,573 & 261,502 \\
\hline \multicolumn{6}{|l|}{ Plus: } \\
\hline Net private transfers from abroad & 6,261 & 7,568 & 9,591 & 11,041 & 11,692 \\
\hline $\begin{array}{l}\text { Net transfers to domestic households } \\
\text { and private nonprofit institutions }\end{array}$ & 24,227 & 28,120 & 32,438 & 39,646 & 44,789 \\
\hline \multicolumn{6}{|l|}{ Less: } \\
\hline $\begin{array}{l}\text { Public sector income from property } \\
\text { and entrepreneurship }\end{array}$ & 2,342 & 2,113 & 2,376 & 4,018 & 3,973 \\
\hline Public sector consumption of fixed capital & 2,328 & 2,608 & 2,917 & 3,415 & 3,880 \\
\hline Private income & 164,533 & 192,736 & 231,330 & 268,827 & 310,130 \\
\hline Less: Direct taxes $1 /$ & 28,160 & 34,673 & 44,669 & 53,567 & 59,847 \\
\hline Gross private disposable income & 136,373 & 158,063 & 186,661 & 215,260 & 250,283 \\
\hline Private consumption & 98,079 & 116,563 & 142,768 & 161,831 & 187,831 \\
\hline \multirow[t]{2}{*}{ Private savings } & 38,294 & 41,500 & 43,893 & 53,429 & 62,452 \\
\hline & \multicolumn{5}{|c|}{ (Percent of gross private disposable income) } \\
\hline Private consumption & 71.9 & 73.7 & 76.5 & 75.2 & 75.0 \\
\hline Private savings & 28.1 & 26.3 & 23.5 & 24.8 & 25.0 \\
\hline
\end{tabular}

Sources: Central Bureau of Statistics, Current Briefings in Statistics; and data provided by the Bank of Israel.

1/ Including contribution to National Insurance Institute. 
Table A6. Israel: National Saving, Foreign Savings, and Investment, 1992-96

\begin{tabular}{|c|c|c|c|c|c|}
\hline & 1992 & 1993 & 1994 & 1995 & 1996 \\
\hline & \multicolumn{5}{|c|}{ (In percent of total income) $1 /$} \\
\hline Gross national savings & 22.2 & 20.3 & 18.6 & 17.8 & 17.1 \\
\hline General government & 1.1 & 0.6 & 0.8 & -0.7 & -1.7 \\
\hline Private sector & 21.1 & 19.7 & 17.8 & 18.5 & 18.8 \\
\hline Foreign savings & -0.2 & 1.3 & 3.0 & 4.3 & 5.8 \\
\hline Current account & 0.5 & -1.0 & -2.7 & -4.0 & -5.5 \\
\hline Civilian import surplus & 5.9 & 6.4 & 7.9 & 9.1 & 7.9 \\
\hline Unilateral transfers & 6.4 & 5.4 & 5.2 & 5.1 & 2.4 \\
\hline Transfers on capital account & 0.3 & 0.3 & 0.3 & 0.3 & 0.3 \\
\hline Gross investment & 22.1 & 21.7 & 21.6 & 22.0 & 21.9 \\
\hline Inventories & 1.1 & 1.3 & 0.7 & 0.7 & 0.7 \\
\hline Fixed residential & 7.9 & 5.7 & 5.4 & 6.4 & 6.7 \\
\hline Fixed nonresidential & 13.1 & 14.7 & 15.5 & 14.9 & 14.5 \\
\hline
\end{tabular}

Source: Bank of Israel, Annual Report 1996.

1/ Total income defined as GNP plus unilateral transfers from abroad. 
Table A7. Israel: Industrial Production Indices, 1992-97

\begin{tabular}{|c|c|c|c|c|c|c|c|}
\hline & \multirow[t]{2}{*}{ Weight } & \multicolumn{6}{|c|}{ Percentage change at constant prices } \\
\hline & & 1992 & 1993 & 1994 & 1995 & 1996 & $19971 /$ \\
\hline Food, beverages, and tobacco & 12.7 & 2.6 & 8.0 & 6.6 & 8.2 & 0.2 & 2.7 \\
\hline Textiles, clothing, and leather & 6.7 & 5.8 & 5.8 & 10.7 & 2.4 & -5.6 & -4.5 \\
\hline Wood, furniture, paper, and printing & 12.1 & 9.7 & 13.0 & 7.0 & 3.8 & 3.0 & 0.5 \\
\hline Chemicals, rubber, and plastics & 15.2 & 11.1 & 11.5 & 11.0 & 7.5 & 8.3 & -0.3 \\
\hline Mining and nonmetallic minerals & 6.5 & 12.2 & 3.0 & 5.4 & 18.0 & 8.4 & -0.3 \\
\hline Basic metals and metal products & 12.5 & 5.5 & 4.2 & 11.0 & 12.6 & 5.2 & 4.6 \\
\hline Machinery and equipment (incl. electric) & 7.0 & 10.8 & 12.4 & 5.0 & 4.3 & 1.1 & -5.0 \\
\hline Transport equipment & 5.7 & 9.3 & -6.9 & -8.0 & 0.7 & 5.5 & 2.9 \\
\hline Electronic equipment & 19.9 & 4.2 & 5.9 & 8.4 & 9.0 & 6.5 & 2.7 \\
\hline Jewelry and miscellaneous articles & 1.8 & 21.3 & 4.8 & 10.4 & 15.4 & 7.1 & 4.3 \\
\hline Total industrial production & 100.0 & 8.2 & 6.8 & 7.4 & 8.4 & 5.4 & 0.8 \\
\hline
\end{tabular}

Sources: Central Bureau of Statistics, Monthly Bulletin of Statistics; and data provided by the Bank of Israel.

1/ Data for the first six months; percentage change relative to the same period in the previous year. 
Table A8. Israel: Labor Market Indicators, 1992-97

\begin{tabular}{|c|c|c|c|c|c|c|c|}
\hline & \multirow{2}{*}{$\frac{\text { In thousands }}{1996}$} & \multicolumn{6}{|c|}{ Percentage change } \\
\hline & & 1992 & 1993 & 1994 & 1995 & 1996 & $19971 /$ \\
\hline Israeli working-age population $2 /$ & 4,020 & 4.3 & 3.0 & 2.9 & 3.0 & 3.0 & 2.8 \\
\hline Israeli civilian labor force & 2,157 & 4.9 & 4.8 & 4.3 & 4.0 & 2.2 & 2.3 \\
\hline Total Israelis employed & 2,013 & 4.2 & 6.1 & 6.9 & 5.0 & 2.4 & 2.5 \\
\hline Public services & 566 & 3.2 & 3.5 & 4.8 & 4.0 & 3.9 & 2.8 \\
\hline Business sector & 1,447 & 5.9 & 4.7 & 7.2 & 7.7 & 1.9 & 2.4 \\
\hline Workers from administered areas & 42 & 18.1 & -27.3 & -16.7 & -14.3 & -31.7 & 43.0 \\
\hline Foreign workers $3 /$ & 119 & $\ldots$ & $\ldots$ & 75.0 & 107.1 & 29.3 & 12.0 \\
\hline Total employed & 2,174 & 5.0 & 4.9 & 6.4 & 5.9 . & 2.7 & 1.3 \\
\hline \multicolumn{8}{|l|}{ Memorandum items: } \\
\hline $\begin{array}{l}\text { Participation rate (in percent of } \\
\text { working-age population) }\end{array}$ & & 52.0 & 52.9 & 53.6 & 54.1 & 53.7 & 53.4 \\
\hline $\begin{array}{l}\text { Unemployment rate (in percent of } \\
\text { civilian labor force) }\end{array}$ & & 11.2 & 10.0 & 7.8 & 6.9 & 6.7 & 7.1 \\
\hline
\end{tabular}

Sources: Bank of Israel, Annual Report; Central Bureau of Statistics, Monthly Bulletin of Statistics; and data provided by the Bank of Israel.

1/ Data for the first six months; percentage change relative to the same period in the previous year.

2/ Aged 15 and above.

$3 /$ Includes unreported foreign workers. 
Table A9. Israel: Employment and Labor Input by Industry, 1992-96 1/

\begin{tabular}{|c|c|c|c|c|c|c|}
\hline & \multirow[b]{2}{*}{1996} & \multicolumn{5}{|c|}{ Annual percentage change } \\
\hline & & 1992 & 1993 & 1994 & 1995 & 1996 \\
\hline Employed persons 2/ & (In thousands) & & & & & \\
\hline Total 3/ & 2,013 & 4.2 & 6.1 & 6.9 & 5.0 & 2.4 \\
\hline Agriculture & 51 & 4.2 & 7.4 & 1.6 & -11.7 & -11.1 \\
\hline Industry & 405 & 2.7 & 6.5 & 6.7 & 2.2 & 0.2 \\
\hline Public utilities & 19 & -13.7 & 21.4 & 15.3 & -5.4 & -3.1 \\
\hline Construction & 150 & 2.6 & -3.4 & 21.2 & 3.3 & 6.7 \\
\hline Commerce & 255 & 2.6 & -3.4 & 21.2 & 3.3 & 2.7 \\
\hline Hotels and restaurants & 76 & 2.2 & 7.3 & 22.1 & 10.6 & -6.3 \\
\hline Transport, storage, and communication & 124 & 7.8 & 2.4 & 3.0 & 2.0 & 8.2 \\
\hline Banking, insurance, and finance & 68 & 2.1 & 6.8 & 6.4 & 4.0 & -0.1 \\
\hline Business services & 194 & 8.4 & 6.8 & 12.5 & 11.9 & 9.8 \\
\hline Community, social, and personal services & 95 & 11.4 & 6.1 & 5.1 & 10.0 & 3.3 \\
\hline Civil service & 108 & -0.9 & 0.0 & 7.3 & -0.7 & 0.7 \\
\hline Education & 243 & 3.5 & 2.9 & 4.5 & 5.9 & 3.1 \\
\hline Health and welfare & 179 & 3.8 & 7.8 & 6.3 & 7.0 & 4.1 \\
\hline Private household services & 34 & 5.0 & 13.4 & 11.8 & 11.6 & 3.7 \\
\hline Foreign organizations & 1 & 10.0 & 9.1 & 0.0 & 16.7 & -23.1 \\
\hline Labor input & $\begin{array}{l}\text { (In millions of } \\
\text { man-hours) }\end{array}$ & & & & & \\
\hline Total 3/ & 76.1 & 6.9 & 6.4 & 8.6 & 5.6 & 2.7 \\
\hline Agriculture & 2.1 & 3.7 & 9.4 & 2.9 & -7.9 & -10.9 \\
\hline Industry & 16.9 & 6.4 & 7.5 & 7.3 & 3.7 & 0.5 \\
\hline Public utilities & 0.8 & -11.5 & 18.7 & 19.2 & -4.3 & -0.3 \\
\hline Construction & 6.6 & 3.4 & -1.7 & 24.7 & 5.9 & 6.0 \\
\hline Commerce & 10.6 & 5.4 & -2.5 & 22.1 & 2.5 & 3.2 \\
\hline Hotels and restaurants & 3.0 & 7.2 & 4.1 & 32.1 & 0.9 & -5.6 \\
\hline Transport, storage, and communication & 5.2 & $8.6^{\circ}$ & 4.8 & 6.6 & 1.7 & 8.7 \\
\hline Banking, insurance, and finance & 2.5 & 4.1 & 6.8 & 7.8 & 3.4 & -0.9 \\
\hline Business services & 7.5 & 11.3 & 6.2 & 13.4 & 11.9 & 10.7 \\
\hline Community, social, and personal services & 3.1 & 16.1 & 4.5 & 3.9 & 10.3 & 1.1 \\
\hline Civil service & 4.2 & -1.7 & 0.0 & 9.3 & -0.2 & 1.9 \\
\hline Education & 6.3 & 6.1 & 0.9 & 7.9 & 7.9 & 1.5 \\
\hline Health and welfare & 6.0 & 5.7 & 8.8 & 6.0 & 7.0 & 7.0 \\
\hline Private household services & 0.8 & 8.8 & 10.0 & 17.7 & 17.1 & 8.5 \\
\hline Foreign organizations & 0.0 & 16.2 & 6.2 & 12.6 & 20.2 & -24.2 \\
\hline
\end{tabular}

Sources: Central Bureau of Statistics, Monthly Bulletin of Statistics ; and Bank of Israel, Anmual Report 1996.

1/ Employment figures are annual averages; labor input figures are weekly averages.

$2 /$ Israeli employees.

3/ Data do not sum to total due to an "unknown" category. 
Table A10. Israel: Real Wages, Labor Costs, and Productivity, 1992-96

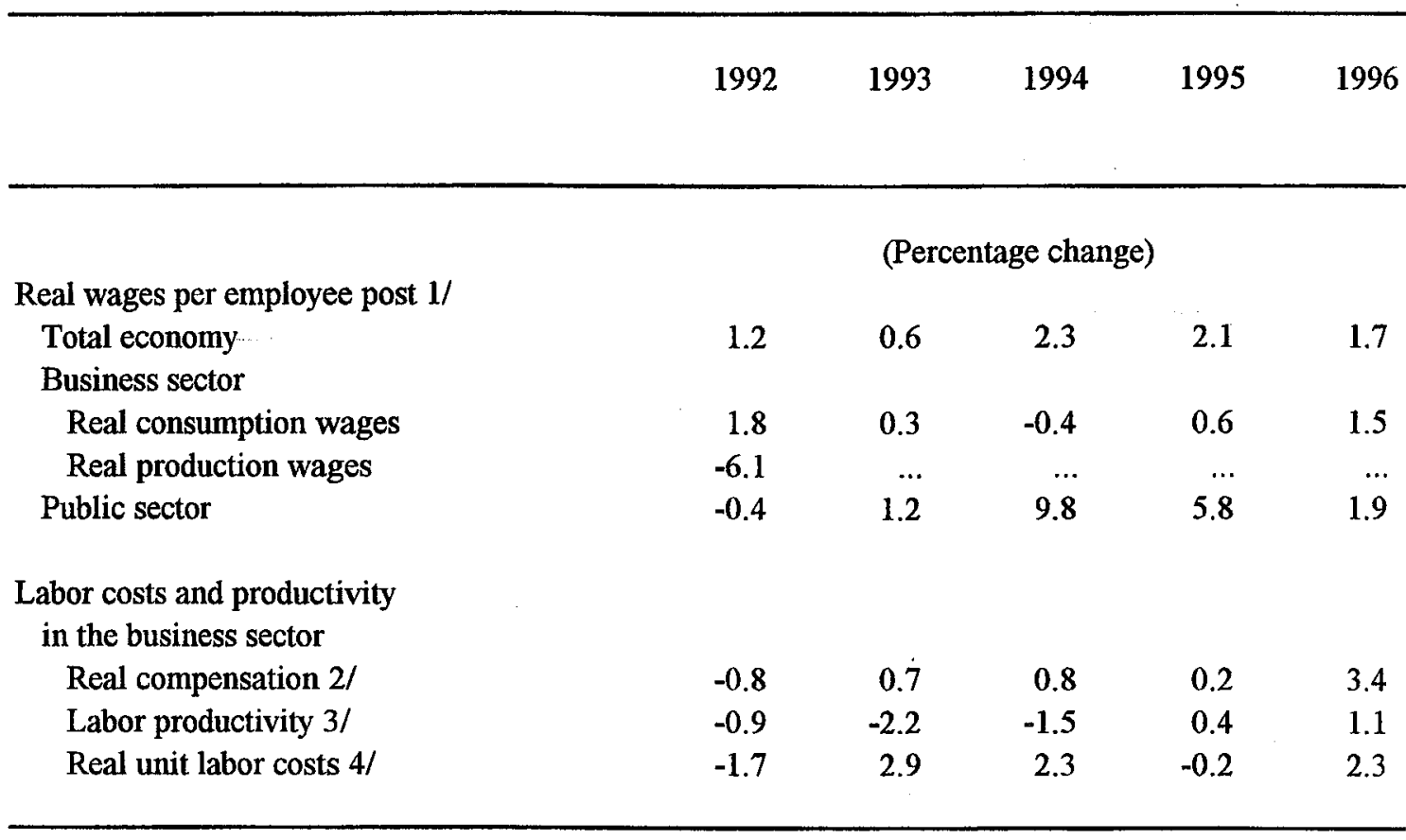

Sources: Bank of Israel, Annual Report 1996; and data provided by the Bank of Israel.

1/ Real wages in the public sector and real consumption wages in the business sector are deflated by the consumer price index; real production wages are deflated by the implicit price index of business sector net domestic product at factor cost.

2/ Measured on an hourly basis; deflated by the implicit price index of business sector net domestic product at factor cost.

3/ Business sector net domestic product per man-hour estimated from the expenditure side.

4/ Ratio of real labor cost per man-hour to labor productivity. 
Table A11. Israel: Real Wage Indices, 1992-97 1/

\begin{tabular}{|c|c|c|c|}
\hline & $\begin{array}{r}\text { Public } \\
\text { Services }\end{array}$ & $\begin{array}{r}\text { Business } \\
\text { Sector }\end{array}$ & Total \\
\hline & \multicolumn{3}{|c|}{$(1994=100)$} \\
\hline 1992 & 90.0 & 100.1 & 96.9 \\
\hline 1993 & 91.1 & 100.4 & 97.5 \\
\hline 1994 & 100.0 & 100.0 & 100.0 \\
\hline 1995 & 105.8 & 100.7 & 102.1 \\
\hline 1996 & 107.8 & 102.2 & 103.8 \\
\hline \multicolumn{4}{|l|}{1995} \\
\hline I & 101.8 & 100.3 & 100.3 \\
\hline II & 110.6 & 100.1 & 100.1 \\
\hline III & 110.0 & 101.8 & 101.8 \\
\hline IV & 100.9 & 100.7 & 100.7 \\
\hline \multicolumn{4}{|l|}{1996} \\
\hline I & 104.4 & 102.2 & 102.2 \\
\hline II & 110.9 & 101.3 & 101.3 \\
\hline III & 112.0 & 102.1 & 102.1 \\
\hline IV & 104.1 & 103.3 & 103.3 \\
\hline \multicolumn{4}{|l|}{1997} \\
\hline I & 104.8 & 102.9 & 102.9 \\
\hline II & 109.6 & 103.7 & 103.7 \\
\hline
\end{tabular}

Source: Data provided by the Bank of Israel.

1/ Average monthly wage per employee post at constant prices, based on employers' contributions to the National Insurance Institute, deflated by the consumer price index. Data from 1994 are based on a new sample and a new definition of "public services;" data from earlier years were connected via linking indices. 


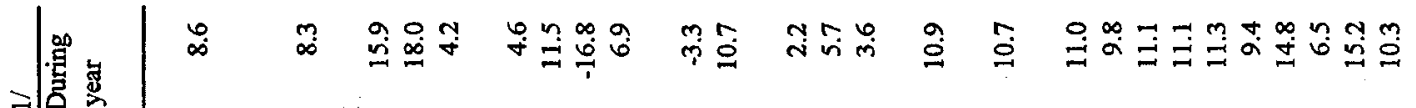

ลे

预

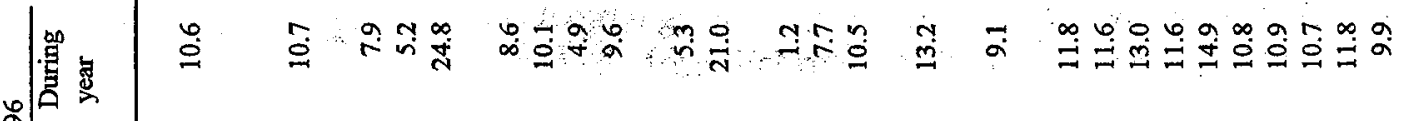

2.

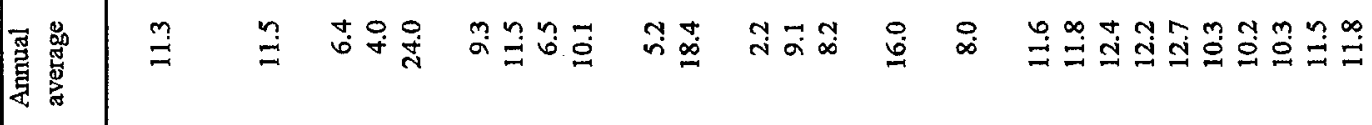

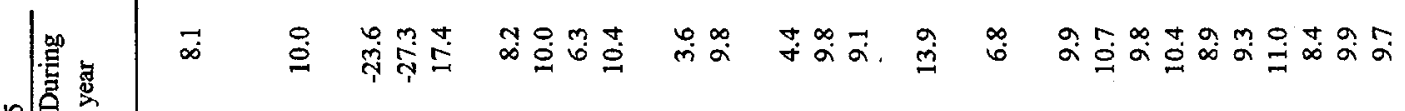

よ̆

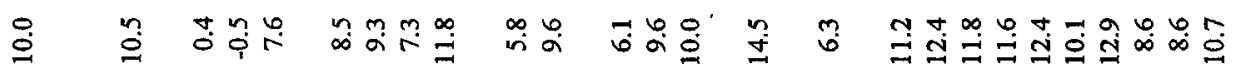

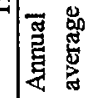

最总

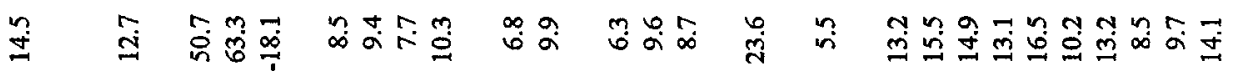

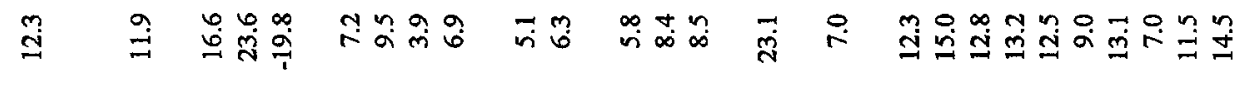

焉㺃

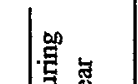

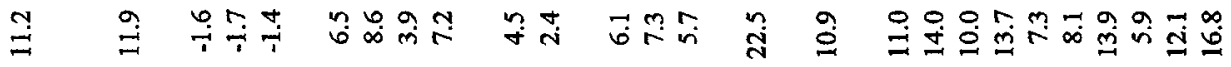

ă

章弯

○े

ホ。

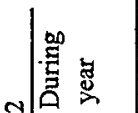

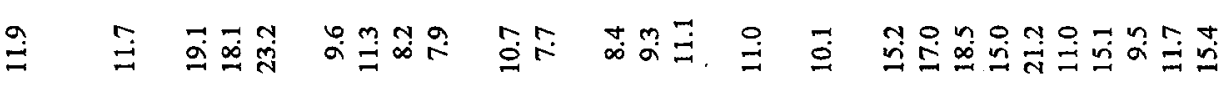

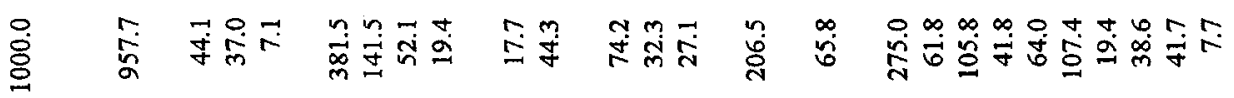
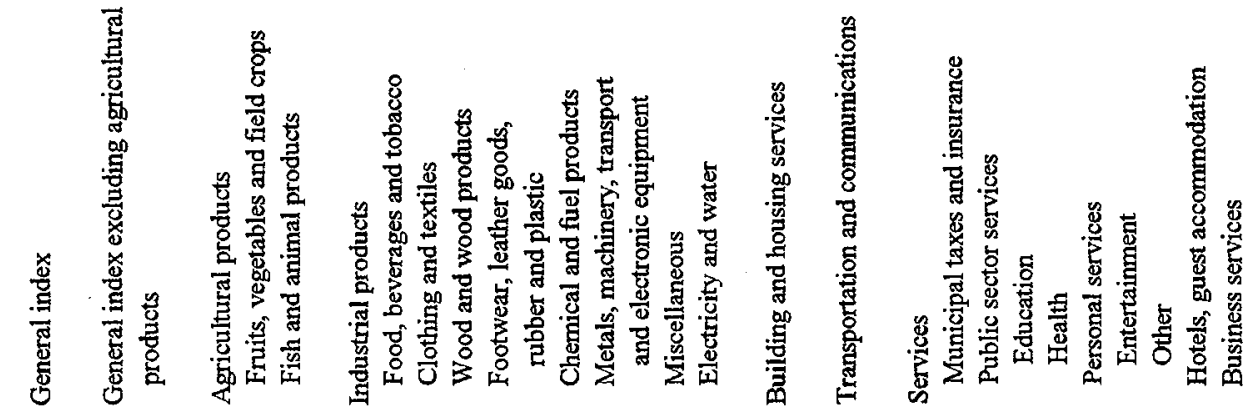
Table A13. Israel: Selected Price Indices, 1992-97

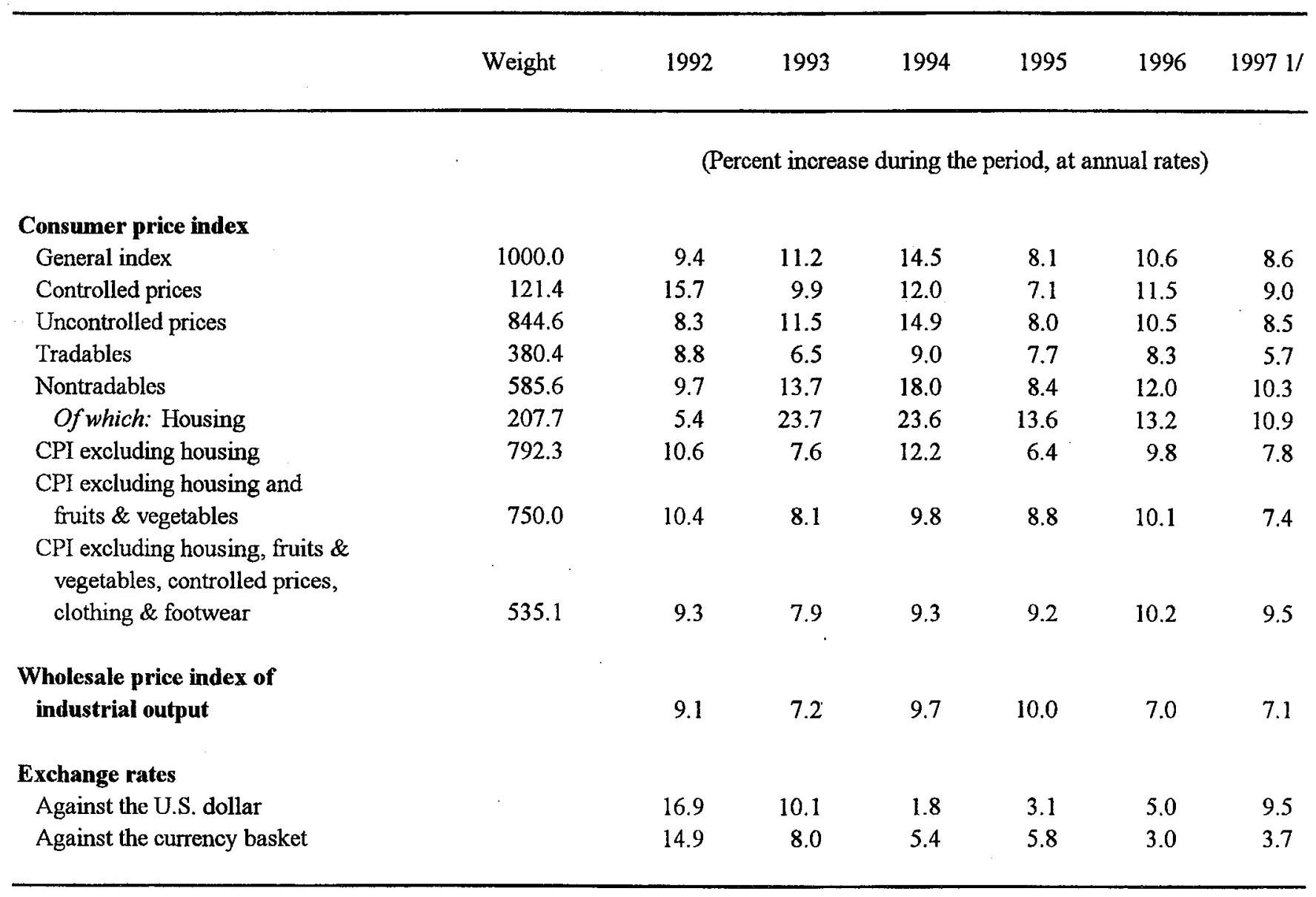

Sources: Central Bureau of Statistics, Monthly Bulletin of Statistics; IMF, International Finoncial Statistics; and data provided by the Bank of Israel.

1/ Twelve-month rate through September. 
Table A14. Israel: Regulated Prices in the Consumer Price Index

(as of August 1997)

Weight

(from 1000)
Weight

(from 1000)

\section{A. Controlled prices}

Public bus transportation

Meat

Municipal taxes

Electricity (for domestic use)

Water (for domestic use)

Education fees

Sick Fund services

Train and domestic flight tickets

Phone services

Mail services

Total

121.4

14.7

7.8

20.0

18.4

8.6

22.7

8.1

0.3

20.3

0.5

\section{B. Prices under supervision}

Flour

1.5

Margarine

0.8

Yogurt

5.7

Bread

9.0

Milk

7.6

1.1

0.5

9.8

$\begin{array}{ll}\text { Refrigerators } & 5.0 \\ \text { School books } & 4.4\end{array}$

$\begin{array}{ll}\text { Refrigerators } & 5.0 \\ \text { School books } & 4.4\end{array}$

Medicines $\quad 4.2$

Gas (for domestic use) $\quad 3.2$

Oil and fuel (for domestic use) $\quad 0.4$

Taxi rides

Total

56.6

Source: Bank of Israel. 
Table A15. Israel: Bank of Israel Accounts, 1992-97

\begin{tabular}{|c|c|c|c|c|c|c|}
\hline & \multirow[t]{2}{*}{1992} & \multirow[t]{2}{*}{1993} & \multirow[t]{2}{*}{1994} & \multirow[t]{2}{*}{1995} & \multirow[t]{2}{*}{1996} & \multirow{2}{*}{$\frac{1997}{\text { September }}$} \\
\hline & & & & & & \\
\hline. & \multicolumn{6}{|c|}{ (In millions of new sheqalim; end of period) } \\
\hline Total assets & 36,103 & 46,881 & 46,677 & 41,674 & 51,465 & 84,579 \\
\hline Foreign assets & 14,185 & 19,063 & 20,507 & 25,576 & 37,126 & 66,347 \\
\hline \multicolumn{7}{|l|}{ Domestic assets } \\
\hline Credit to the government (long term debt) & 8,644 & 8,373 & 8,080 & 7,773 & 7,448 & 7,456 \\
\hline Loans and notes & 11,053 & 16,972 & 15,564 & 4,503 & 1,236 & 3,763 \\
\hline Monetary & 10,507 & 16,501 & 15,011 & 4,009 & 957 & 3,655 \\
\hline Other & 546 & 471 & 553 & 494 & 279 & 108 \\
\hline Government securities & 1,775 & 1,965 & 1,896 & 3,045 & 4,856 & 5,338 \\
\hline Other accounts & 446 & 508 & 630 & 777 & 799 & 1,675 \\
\hline Total liabilities & 36,103 & 46,881 & 46,677 & 41,674 & 51,465 & 84,579 \\
\hline Foreign liabilities & 1,190 & 1,286 & 1,366 & 1,242 & 724 & 614 \\
\hline Allocations of SDRs & 405 & 437 & 467 & 496 & 496 & $\ldots$ \\
\hline \multicolumn{7}{|l|}{ Liabilities to international monetary } \\
\hline organizations & 785 & 849 & 899 & 746 & 228 & $\ldots$ \\
\hline Currency in circulation & 4,793 & 5,652 & 6,454 & 7,916 & 9,222 & 10,199 \\
\hline Deposits of the government & 11,694 & 16,165 & 17,456 & 19,325 & 23,013 & 30,975 \\
\hline In Israeli currency & 8,040 & 8,867 & 6,682 & 16,828 & 15,670 & $\ldots$ \\
\hline In foreign currency & 3,654 & 7,298 & 10,774 & 2,497 & 7,343 & $\cdots$ \\
\hline Deposits of banking institutions & 17,004 & 22,291 & 19,603 & 11,126 & 16,484 & 39,811 \\
\hline In Israeli currency & 1,111 & 2,088 & 3,190 & 1,007 & 8,502 & 32,579 \\
\hline In foreign currency & 15,893 & 20,203 & 16,413 & 10,119 & 7,982 & 7,232 \\
\hline Against resident deposits & & 9,884 & 8,074 & 9,844 & 7,649 & 6,933 \\
\hline Against nonresident deposits & 2,953 & 3,236 & 3,885 & 0 & 0 & 0 \\
\hline Free deposits of banking institutions & $\ldots$ & 7,083 & 4,454 & 275 & 333 & 299 \\
\hline Other deposits and accounts & 1,102 & 1,167 & 1,478 & 1,745 & 1,952 & 2,910 \\
\hline Capital and reserves & 320 & 320 & 320 & 320 & 70 & 70 \\
\hline
\end{tabular}

Sources: Central Bureau of Statistics, Monthly Bulletin of Statistics ; and data provided by the Bank of Israel. 
Table A16. Israel: Monetary Survey, 1992-97

\begin{tabular}{|c|c|c|c|c|c|c|}
\hline & 1992 & 1993 & 1994 & 1995 & 1996 & 1997 \\
\hline & & & & & & June \\
\hline & \multicolumn{6}{|c|}{ (In millions of new sheqalim; end of period) } \\
\hline Net foreign assets & 9,505 & 12,545 & 14,295 & 16,642 & 28,233 & 36,262 \\
\hline Bank of Israel & 13,400 & 18,214 & 19,608 & 24,830 & 36,898 & 63,827 \\
\hline DMBs & $-3,895$ & $-5,669$ & $-5,313$ & $-8,188$ & $-8,665$ & $-27,565$ \\
\hline Net domestic assets & 138,125 & 158,964 & 182,144 & 232,442 & 272,996 & 287,768 \\
\hline Domestic credit & 145,253 & 167,458 & 194,691 & 235,127 & 272,931 & 289,494 \\
\hline Net claims on government & 52,117 & 46,902 & 41,639 & 50,987 & 54,445 & 49,570 \\
\hline Total gross claims & 72,513 & 75,418 & 76,216 & 80,715 & 89,790 & 87,476 \\
\hline Bank of Israel & 10,419 & 10,338 & 9,975 & 10,804 & 12,265 & 12,383 \\
\hline DMB claims & 62,094 & 65,080 & 66,241 & 69,911 & 77,525 & 75,093 \\
\hline Government bonds & 16,976 & 21,784 & 24,583 & 36,624 & 47,206 & 45,944 \\
\hline From bank resources & 14,744 & 13,399 & 12,078 & 7,031 & 6,802 & 6,120 \\
\hline Foreign currency credit & 2,883 & 2,636 & 2,336 & 1,323 & 650 & 1,195 \\
\hline From earmarked deposits & 27,491 & 27,261 & 27,244 & 24,933 & 22,867 & 21,834 \\
\hline Less: Government deposits held at: & 20,396 & 28,516 & 34,577 & 29,728 & 35,345 & 37,906 \\
\hline Bank of Israel & 5,249 & 8,912 & 11,366 & 3,044 & 7,755 & 9,634 \\
\hline DMBs & 15,147 & 19,604 & 23,211 & 26,684 & 27,590 & 28,272 \\
\hline Mortgage banks & 8,627 & 10,260 & 14,581 & 18,128 & 24,352 & 26,977 \\
\hline Private sector & 84,509 & 110,296 & 138,471 & 166,012 & 194,134 & 212,947 \\
\hline Nondirected credit in Israeli currency & 55,616 & 80,461 & 105,515 & 119,660 & 140,262 & 138,852 \\
\hline Nondirected credit in foreign currency & 12,447 & 12,587 & 15,565 & 33,992 & 42,169 & 61,638 \\
\hline Directed credit in foreign currency & 441 & 403 & 491 & 327 & 152 & 3 \\
\hline Credit from earmarked deposits & 15,018 & 15,761 & 15,739 & 10,994 & 10,610 & 11,473 \\
\hline Securities & 987 & 1,084 & 1,161 & 1,039 & 941 & 981 \\
\hline Other items, net & $-7,128$ & $-8,494$ & $-12,547$ & $-2,685$ & 65 & $-1,726$ \\
\hline Monetary liabilities & 110,239 & 134,667 & 167,419 & 199,732 & 250,111 & 266,807 \\
\hline M1 & 10,567 & 13,571 & 14,608 & 17,034 & 20,294 & 19,983 \\
\hline Quasi-money & 99,672 & 121,096 & 152,811 & 182,698 & 229,817 & 246,824 \\
\hline Time and saving deposits & 89,151 & 104,333 & 139,123 & 166,354 & 211,415 & 228,732 \\
\hline Time deposits & 11,532 & 17,494 & 35,289 & 52,494 & 75,961 & 86,859 \\
\hline Saving schemes & 36,888 & 42,908 & 53,459 & 61,459 & 75,537 & 79,287 \\
\hline Long-term indexed deposits & 10,926 & 11,364 & 13,129 & 12,331 & 13,732 & 14,306 \\
\hline Foreign currency deposits & 29,805 & 32,567 & 37,246 & 40,070 & 46,185 & 48,280 \\
\hline CDs & 10,521 & 16,763 & 13,688 & 16,344 & 18,402 & 18,092 \\
\hline Earmarked deposits & 30,157 & 28,992 & 28,834 & 25,850 & 23,804 & 22,802 \\
\hline
\end{tabular}

Source: Data provided by the Bank of Israel. 
Table A17. Israel: Financial Assets of the Public, 1992-97 1/

\begin{tabular}{|c|c|c|c|c|c|c|}
\hline \multirow{2}{*}{$\ldots \ldots$} & \multirow[t]{2}{*}{1992} & \multirow[t]{2}{*}{1993} & \multirow[t]{2}{*}{1994} & \multirow[t]{2}{*}{1995.} & \multirow[t]{2}{*}{1996} & \multirow{2}{*}{$\frac{1997}{\text { June }}$} \\
\hline & & & & & & \\
\hline & & \multicolumn{5}{|c|}{ (In millions of new sheqalim; end of period) } \\
\hline Total assets in banks and government bonds & $\ldots$ & 228,110 & 265,502 & 302,023 & 358,704 & 386,814 \\
\hline Broad money assets & 139,661 & 163,857 & 196,413 & 226,017 & 274,210 & 289,770 \\
\hline Liquid financial assets (M3) & 50,110 & 67,603 & 86,531 & 109,973 & 145,098 & 157,433 \\
\hline Money supply (M1) & 10,390 & 13,571 & 14,608 & 17,034 & 20,294 & 19,983 \\
\hline Time deposits and negotiable CDs & 21,882 & 34,257 & 48,977 & 68,838 & 94,363 & 104,952 \\
\hline Special deposits $2 /$ & 301 & 194 & 195 & 434 & 295 & 155 \\
\hline Resident foreign currency & 17,537 & 19,581 & 22,751 & 23,667 & 30,146 & 32,343 \\
\hline Medium-term assets & 89,551 & 96,254 & 109,882 & 116,044 & 129,112 & 132,337 \\
\hline Restitution deposits & 12,103 & 12,986 & 14,495 & 16,403 & 16,039 & 15,942 \\
\hline Saving schemes & 36,876 & 42,848 & 53,401 & 61,446 & 75,537 & 79,287 \\
\hline Long-term linked deposits & 10,731 & 11,364 & 13,129 & 12,331 & 13,732 & 14,306 \\
\hline Earmarked deposits & 29,841 & 29,056 & $28,85,7$ & 25,864 & 23,804 & 22,802 \\
\hline Short-term treasury bills & $\ldots$ & 2,560 & 4,262 & 7,393 & 8,934 & 8,888 \\
\hline Tradable linked government bonds 3 / & 58,820 & 61,693 & 64,827 & 68,613 & 75,560 & 88,156 \\
\hline Stocks & 81,907 & 151,607 & 98,800 & 114,500 & 116,600 & 160,900 \\
\hline Total financial assets & $\ldots$ & 379,717 & 364,302 & 416,523 & 475,304 & 547,714 \\
\hline \multirow[t]{2}{*}{ Of which: Nonindexed short term assets } & $\ldots$ & 50,582 & 67,847 & 93,266 & 123,591 & 133,822 \\
\hline & & \multicolumn{5}{|c|}{ (In percent of total financial assets) } \\
\hline Total assets in banks and government bonds & & 60.1 & 72.9 & 72.5 & 75.5 & 70.6 \\
\hline Broad money assets & & 43.2 & 53.9 & 54.3 & 57.7 & 52.9 \\
\hline Liquid financial assets (M3) & & 17.8 & 23.8 & 26.4 & 30.5 & 28.7 \\
\hline Money supply (M1) & & 3.6 & 4.0 & 4.1 & 4.3 & 3.6 \\
\hline Time deposits and negotiable CDs & & 9.0 & 13.4 & 16.5 & 19.9 & 19.2 \\
\hline Special deposits $2 /$ & & 0.1 & 0.1 & 0.1 & 0.1 & 0.0 \\
\hline Resident foreign currency & & 5.2 & 6.2 & 5.7 & 6.3 & 5.9 \\
\hline Medium-term assets & & 25.3 & 30.2 & 27.9 & 27.2 & 24.2 \\
\hline Restitution deposits & & 3.4 & 4.0 & 3.9 & 3.4 & 2.9 \\
\hline Saving schemes & & 11.3 & 14.7 & 14.8 & 15.9 & 14.5 \\
\hline Long-term linked deposits & & 3.0 & 3.6 & 3.0 & 2.9 & 2.6 \\
\hline Earmarked deposits & & 7.7 & 7.9 & 6.2 & 5.0 & 4.2 \\
\hline Short-term treasury bills & & 0.7 & 1.2 & 1.8 & 1.9 & 1.6 \\
\hline Tradable linked government bonds $3 /$ & & 16.2 & 17.8 & 16.5 & 15.9 & 16.1 \\
\hline Stocks & & 39.9 & 27.1 & 27.5 & 24.5 & 29.4 \\
\hline Total financial assets & & 100.0 & 100.0 & 100.0 & 100.0 & 100.0 \\
\hline \multirow[t]{2}{*}{ Of which: Nonindexed short term assets } & & 13.3 & 18.6 & 22.4 & 26.0 & 24.4 \\
\hline & \multicolumn{6}{|c|}{ (Real rate of growth) 4 / } \\
\hline Total assets in banks and government bonds & & $\ldots$ & 1.7 & 5.2 & 7.4 & 9.8 \\
\hline Broad money assets & & 5.5 & 4.7 & 6.4 & 9.7 & 7.9 \\
\hline Liquid financial assets (M3) & & 21.3 & 11.9 & 17.6 & 19.3 & 16.7 \\
\hline Money supply (M1) & & 17.4 & -5.9 & 7.9 & 7.7 & 2.4 \\
\hline Time deposits and negotiable CDs & & 40.7 & 24.9 & 30.0 & 23.9 & 23.6 \\
\hline Special deposits $2 /$ & & -42.1 & -12.2 & 105.9 & -38.5 & -66.6 \\
\hline Resident foreign currency & & 0.4 & 1.5 & -3.8 & 15.2 & 7.8 \\
\hline Medium-term assets & & -3.4 & -0.2 & -2.3 & 0.6 & -1.0 \\
\hline Restitution deposits & & -3.6 & -2.5 & 4.7 & -11.6 & -8.5 \\
\hline Saving schemes & & 4.4 & 8.9 & 6.4 & 11.1 & 7.5 \\
\hline Long-term linked deposits & & -4.8 & 1.0 & -13.1 & 0.7 & -2.9 \\
\hline Earmarked deposits & & -12.5 & -13.2 & -17.1 & -16.8 & -17.8 \\
\hline Short-term treasury bills & & $\ldots$ & 45.5 & 60.5 & 9.3 & 4.4 \\
\hline Tradable linked government bonds 3 / & & -5.7 & -8.2 & -2.1 & -0.4 & 17.2 \\
\hline Stocks & & 66.4 & -43.1 & 7.2 & -7.9 & 35.1 \\
\hline Total financial assets & & $\ldots$ & -16.2 & 5.8 & 3.2 & 16.2 \\
\hline Of which: Nonindexed short term assets & & $\ldots$ & 17.2 & 27.2 & 19.8 & 18.5 \\
\hline
\end{tabular}

Source: Data provided by the Bank of Israel.

1/ The public consists of individuals and corporations excluding the Government, Bank of Israel, ordinary banking corporations, and banks abroad. It includes social and life insurance funds but does not include the assets of these funds held out of the ordinary banking system.

2/ Noninterest-bearing deposits mandated by law to cover total subscriptions for securities flotations in the TASE

3/ Defined to exclude bond holdings of pension funds and insurance companies.

4/ Nominal rate deflated by consumer price index. 
Table A18. Israel: Commercial Bank Credit to the Private Sector, 1992-97 1/

\begin{tabular}{|c|c|c|c|c|c|c|}
\hline & 1992 & 1993 & 1994 & 1995 & 1996 & $\frac{1997}{\text { September }}$ \\
\hline & \multicolumn{6}{|c|}{ (In millions of new sheqalim; end of period) } \\
\hline Total & 92,159 & 119,482 & 151,892 & 183,167 & 217,594 & 242,476 \\
\hline Short-term credit & 47,561 & 64,236 & 79,013 & 100,469 & 116,439 & 132,314 \\
\hline Nondirected credit & 47,121 & 63,833 & 78,522 & 100,142 & 116,287 & 132,311 \\
\hline In Israeli currency $2 /$ & 34,673 & 51,219 & 62,633 & 65,564 & 73,118 & 71,088 \\
\hline In U.S. dollars & 12,448 & 12,614 & 15,889 & 34,578 & 43,169 & 61,223 \\
\hline Directed credit & 441 & 403 & 491 & 327 & 152 & 3 \\
\hline Medium- and long-term credit & 44,598 & 55,247 & 72,879 & 82,698 & 101,155 & 110,162 \\
\hline \multirow[t]{2}{*}{ Of which: Indexed NIS credit } & 29,569 & 39,475 & 57,139 & 64,989 & 84,019 & 92,564 \\
\hline & \multicolumn{6}{|c|}{ (In percent of total) } \\
\hline Total & 100.0 & 100.0 & 100.0 & 100.0 & 100.0 & 100.0 \\
\hline Short-term credit & 51.6 & 53.8 & 52.0 & 54.9 & 53.5 & 54.6 \\
\hline Nondirected credit & 51.1 & 53.4 & 51.7 & 54.7 & 53.4 & 54.6 \\
\hline In Israeli currency $2 /$ & 37.6 & 42.9 & 41.2 & 35.8 & 33.6 & 29.3 \\
\hline In U.S. dollars & 13.5 & 10.6 & 10.5 & 18.9 & 19.8 & 25.2 \\
\hline Directed credit & 0.5 & 0.3 & 0.3 & 0.2 & 0.1 & 0.0 \\
\hline Medium- and long-term credit & 48.4 & 46.2 & 48.0 & 45.1 & 46.5 & 45.4 \\
\hline \multirow[t]{2}{*}{ Of which: Indexed NIS credit } & 32.1 & 33.0 & 37.6 & 35.5 & 38.6 & 38.2 \\
\hline & \multicolumn{6}{|c|}{ (Nominal percentage increase) } \\
\hline Total & & 29.6 & 27.1 & 20.6 & 18.8 & 15.8 \\
\hline Short-term credit & & 35.1 & 23.0 & 27.2 & 15.9 & 18.5 \\
\hline Nondirected credit & & 35.5 & 23.0 & 27.5 & 16.1 & 18.7 \\
\hline In Israeli currency $2 /$ & & 47.7 & 22.3 & 4.7 & 11.5 & 1.9 \\
\hline In U.S. dollars & & 1.3 & 26.0 & 117.6 & 24.8 & 46.7 \\
\hline Directed credit & & -8.5 & 21.8 & -33.4 & -53.5 & -98.3 \\
\hline Medium- and long-term credit & & 23.9 & 31.9 & 13.5 & 22.3 & 12.8 \\
\hline \multirow[t]{2}{*}{ Of which: Indexed NIS credit } & & 33.5 & 44.7 & 13.7 & 29.3 & 15.6 \\
\hline & \multicolumn{6}{|c|}{ (Real percentage increase) $3 /$} \\
\hline Total & & 16.5 & 11.1 & 11.6 & 7.4 & 6.5 \\
\hline Short-term credit & & 21.4 & 7.5 & 17.6 & 4.8 & 9.0 \\
\hline Nondirected credit & & 21.8 & 7.5 & 18.0 & 5.0 & 9.2 \\
\hline In Israeli currency $2 /$ & & 32.8 & 6.9 & -3.2 & 0.8 & -6.3 \\
\hline In U.S. dollars & & -8.9 & 10.1 & 101.3 & 12.9 & 34.9 \\
\hline Directed credit & & -17.7 & 6.5 & -38.4 & -58.0 & -98.4 \\
\hline Medium- and long-term credit & & 11.3 & 15.3 & 5.0 & 10.6 & 3.7 \\
\hline Of which: Indexed NIS credit & & 20.0 & 26.5 & 5.2 & 16.9 & 6.3 \\
\hline
\end{tabular}

Source: Data provided by the Bank of Israel.

1/ Includes credit to local authorities (the credit excludes deductions for loan-loss provisions).

$2 /$ Includes indexation increments.

3/ Nominal rate deflated by consumer price index. 


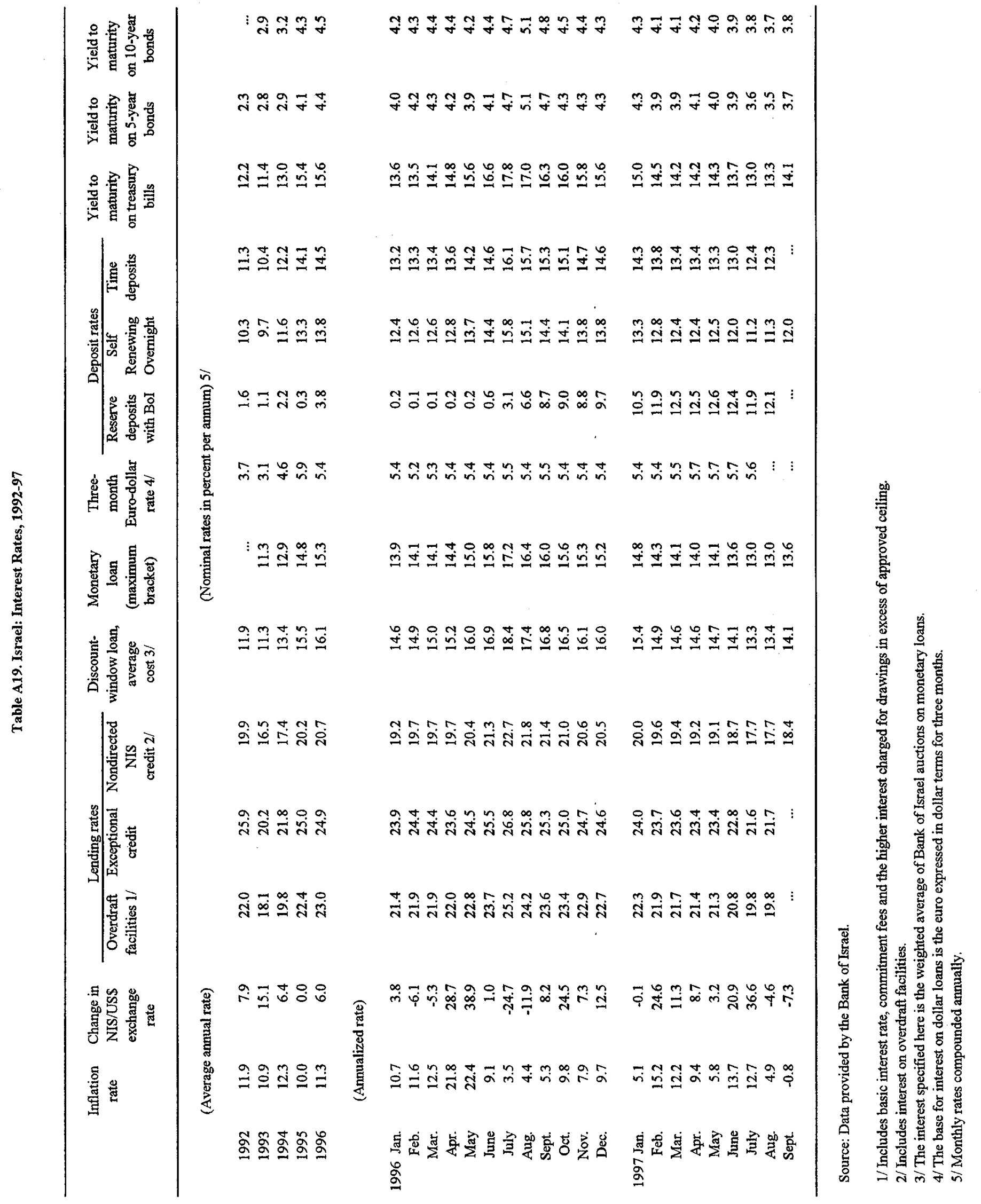




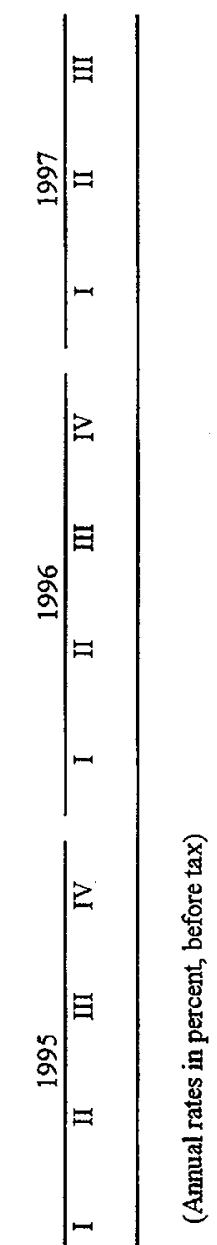

窟

ஃ̊

ฒ



ू $\vdots \quad \vdots \quad \vdots \quad \vdots \quad \vdots \quad \vdots m$

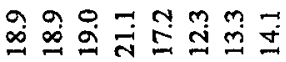

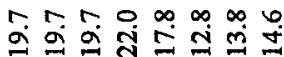

눈

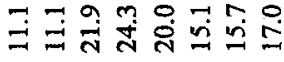

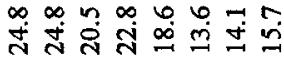

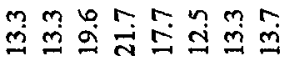

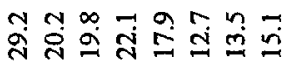

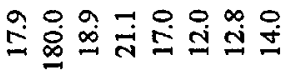

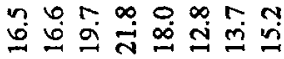

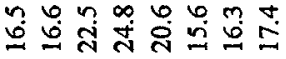

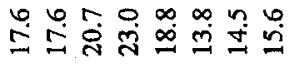

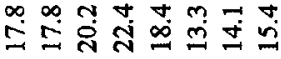

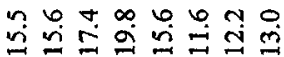

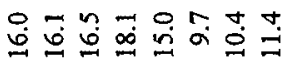

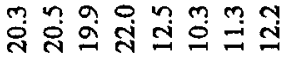

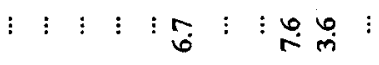

n

के क्ष

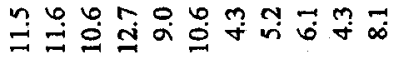

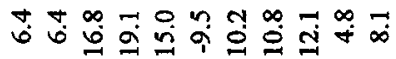

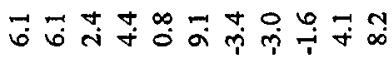

开

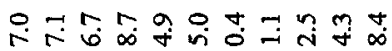

풍ํำ

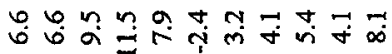



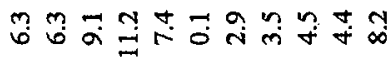

웅유 쏧

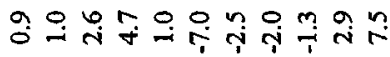

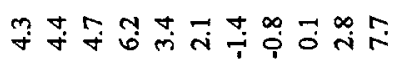

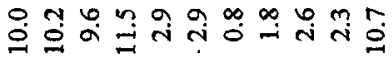

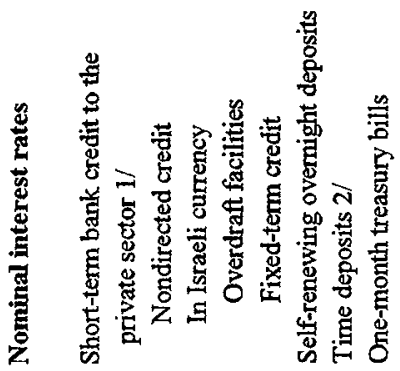

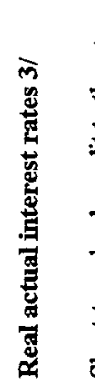

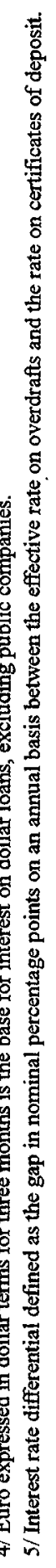


Table A21. Israel: Reserve Requirements on Deposits and Interest Brackets, 1992-97

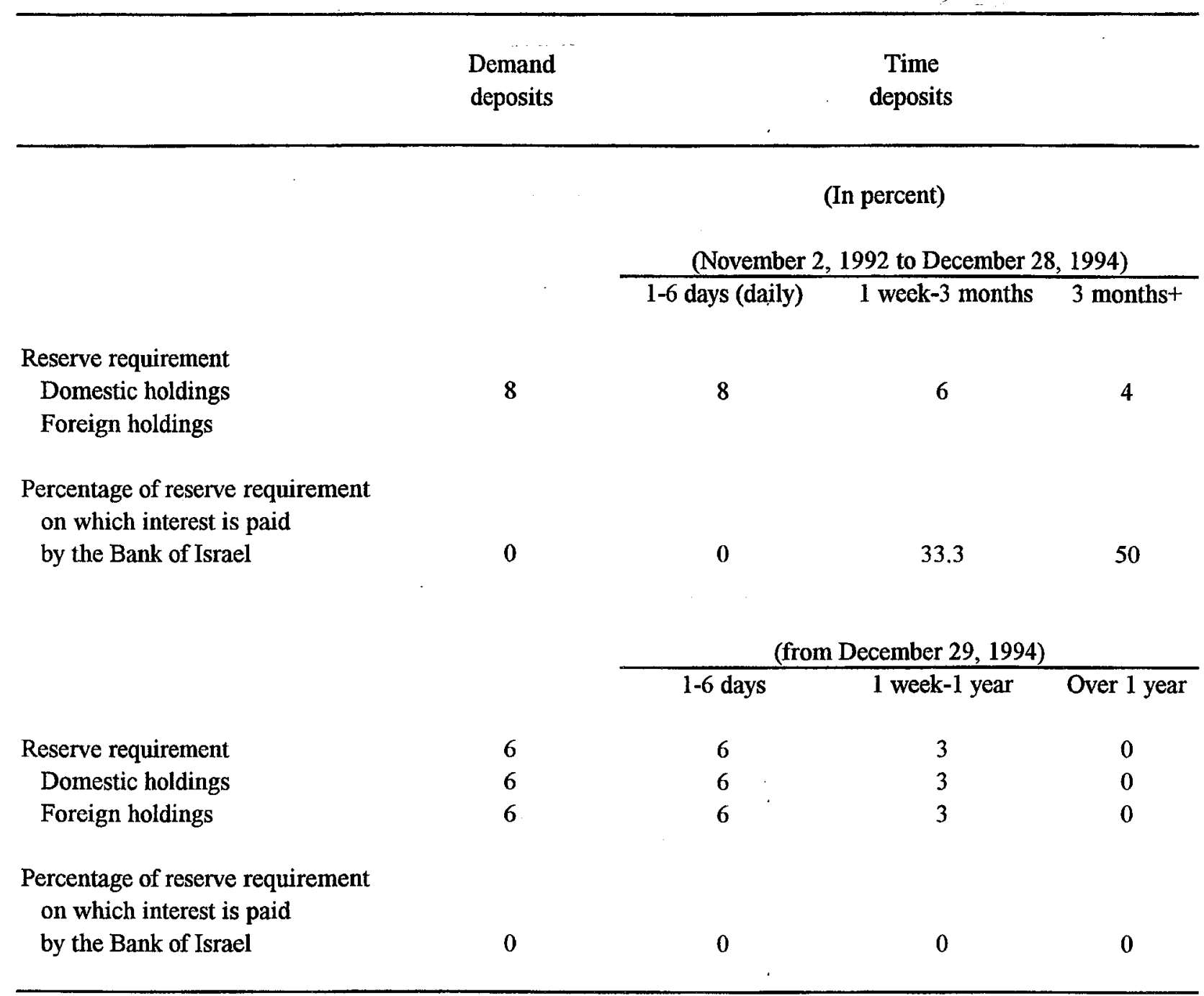

Source: Bank of Israel. 


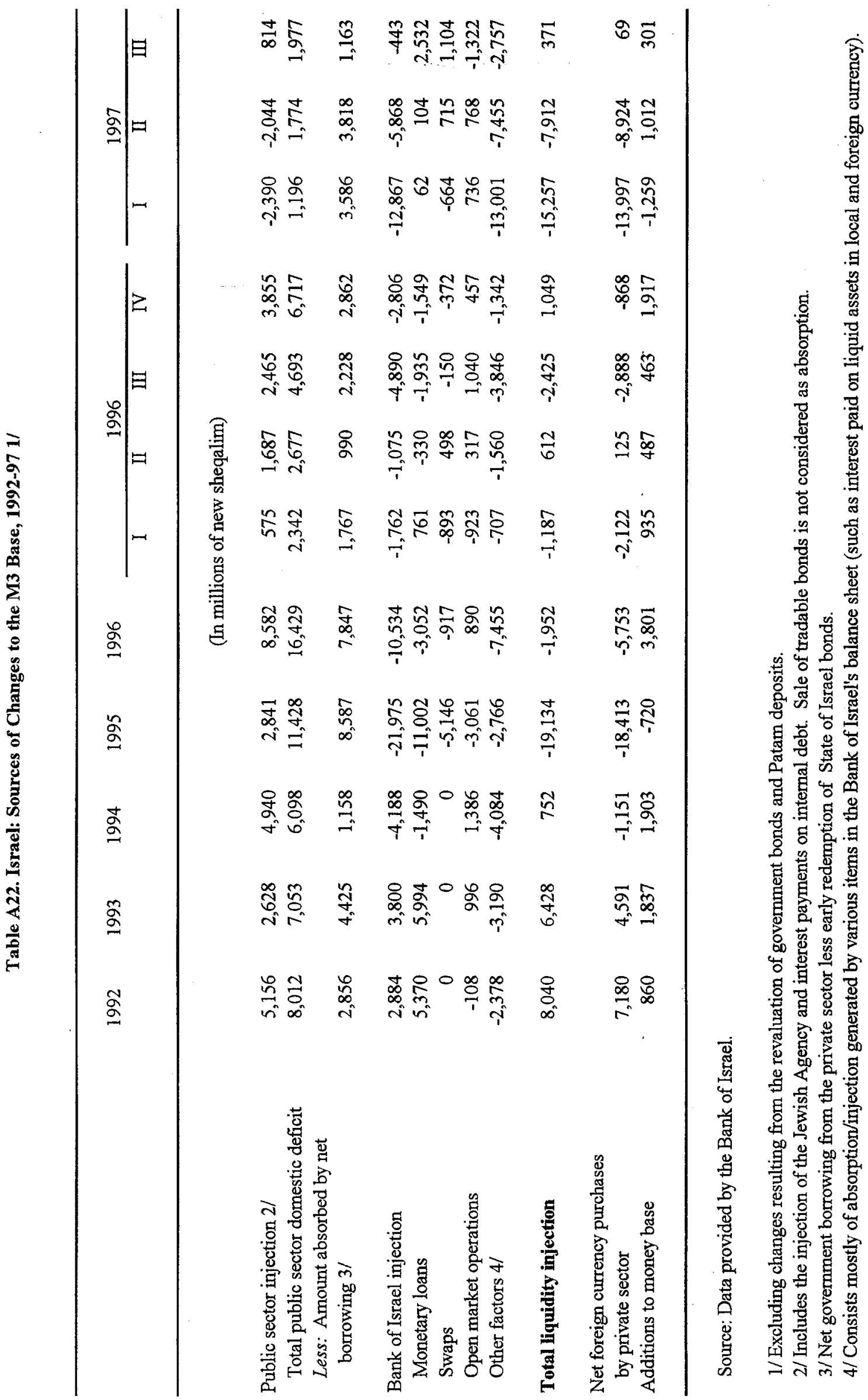


Table A23. Israel: Factors Affecting the M3 Base, 1992-97

\begin{tabular}{|c|c|c|c|c|c|c|}
\hline & 1992 & 1993 & $\cdot 1994$ & 1995 & 1996 & $\frac{1997 \text { 1/ }}{\text { September }}$ \\
\hline & \multicolumn{5}{|c|}{ (In millions of new sheqalim; end of period) } & \\
\hline M3 base & 9,139 & 10,127 & 11,184 & 10,858 & 14,843 & 14,696 \\
\hline \multicolumn{6}{|l|}{ Reserve requirements on } & 12,778 \\
\hline \multirow[t]{2}{*}{ Patam deposits } & 3,236 & 2,387 & 1,541 & 1,935 & 2,119 & 1,918 \\
\hline & \multicolumn{6}{|c|}{ (Real percentage increase during the period) $3 /$} \\
\hline M3 base & -2.5 & -0.4 & -3.5 & -10.2 & 23.6 & -20.7 \\
\hline Narrow money base $2 /$ & 7.0 & 17.9 & 8.9 & -14.4 & 28.9 & 8.8 \\
\hline \multicolumn{7}{|l|}{ Reserve requirements on } \\
\hline Patam deposits & -16.2 & -33.7 & -43.6 & 16.2 & -1.0 & -71.7 \\
\hline & \multicolumn{6}{|c|}{ (In percent) } \\
\hline \multicolumn{7}{|c|}{$\begin{array}{l}\text { Percent of increase in narrow liquid asset } \\
\text { base due to: }\end{array}$} \\
\hline Revaluation increments & 99.8 & 18.0 & 1.5 & -22.1 & 1.9 & -6.5 \\
\hline \multirow[t]{2}{*}{ Nonrevaluation increments } & 0.2 & 82.0 & 98.5 & 122.1 & 98.1 & 106.5 \\
\hline & \multicolumn{6}{|c|}{ (In millions of new sheqalim; flows) } \\
\hline \multicolumn{7}{|l|}{ Memorandum items: } \\
\hline Increase in $\mathrm{M} 3$ base & 565 & 986 & 1,058 & -327 & 3,986 & $-2,346$ \\
\hline \multicolumn{7}{|l|}{ Of which: } \\
\hline $\begin{array}{l}\text { Revaluation increments on Patan } \\
\text { deposits' reserve requirements }\end{array}$ & 563 & 177 & 16 & 72 & 76 & 152 \\
\hline Nonrevaluation increments & 1 & 809 & 1,041 & -399 & 3,910 & $-2,497$ \\
\hline
\end{tabular}

Source: Data provided by the Bank of Israel.

1/ Period of change relates to September 1997 versus September 1996.

2/ Currency held by public and liquid assets of banking institutions.

3 / Nominal rate deflated by consumer price index. 
Table A24. Israel: The Israeli Capital Market, 1996

\begin{tabular}{|c|c|c|c|c|c|c|}
\hline & Total & Shares I/ & $\begin{array}{l}\text { Tradable } \\
\text { bonds } 2 /\end{array}$ & $\begin{array}{l}\text { Indexed } \\
\text { earmarked } \\
\text { bonds }\end{array}$ & $\begin{array}{l}\text { Treasury } \\
\text { bills } 2 /\end{array}$ & $\begin{array}{c}\text { Other } \\
\text { assets } \\
\text { held by } \\
\text { institutions }\end{array}$ \\
\hline & \multicolumn{6}{|c|}{ (In billions of new sheqalim; end of period) } \\
\hline \multicolumn{7}{|l|}{ Institutions } \\
\hline Provident funds & 109.1 & 11.0 & 49.4 & 10.6 & 0.6 & 37.4 \\
\hline Pension funds & 78.1 & 0.0 & 0.3 & 73.3 & 0.0 & 4.6 \\
\hline Life insurance & 39.2 & 0.7 & 4.6 & 26.3 & 0.0 & 7.6 \\
\hline Mutual funds $3 /$ & 12.7 & 5.0 & 6.6 & 0.0 & 0.6 & 0.4 \\
\hline Households and firms & 64.3 & 28.3 & 28.6 & 0.0 & 7.4 & 0.0 \\
\hline Nonresidents & 17.4 & 16.5 & 0.8 & 0.0 & 0.1 & 0.0 \\
\hline Banks & 45.2 & 0.0 & 37.3 & 0.0 & 7.8 & 0.0 \\
\hline Total & 365.5 & 61.6 & 127.6 & 110.2 & 16.5 & 49.6 \\
\hline & \multicolumn{6}{|c|}{ (Real percentage change from 1995) } \\
\hline \multicolumn{7}{|l|}{ Institutions } \\
\hline Provident funds & -10.0 & -21.5 & -14.6 & -17.9 & -59.6 & 5.7 \\
\hline Pension funds & 4.2 & $\therefore$ & -- & 4.8 & -- & -5.2 \\
\hline Life insurance & 13.6 & 26.6 & 37.5 & 9.7 & -- & 16.6 \\
\hline Mutual funds 3/ & -24.7 & -36.6 & -10.8 & -- & -32.2 & -40.0 \\
\hline Households and firms & -12.7 & -7.5 & 37.6 & -- & 30.7 & -40.0 \\
\hline Nonresidents & 8.5 & 8.9 & 20.6 & -- & -9.6 & -- \\
\hline Banks & 9.5 & -- & 9.6 & -- & 9.0 & -- \\
\hline Total & 1.3 & -9.9 & 2.8 & 3.8 & 7.6 & 4.7 \\
\hline $\begin{array}{l}\text { Real change in price } \\
\text { (in percent) }\end{array}$ & 2.5 & -12.0 & -1.0 & - & $\cdots$ & -- \\
\hline $\begin{array}{l}\text { Real change in quantity } \\
\text { (in percent) }\end{array}$ & 3.8 & 2.4 & 3.8 & 3.8 & 7.6 & 4.7 \\
\hline
\end{tabular}

Source: Data provided by the Bank of Israel.

1/ Excluding double counting and government-owned quoted companies.

2/ Excluding securities held by the Bank of Israel.

3/ Adjusted for provident funds' and nonresidents' holdings in mutual funds. 
Table A25. Israel: Principal Stock Market Indicators, 1992-96

\begin{tabular}{|c|c|c|c|c|c|}
\hline & 1992 & 1993 & 1994 & 1995 & 1996 \\
\hline & \multicolumn{5}{|c|}{ (In millions of 1996 new sheqalim) } \\
\hline \multicolumn{6}{|l|}{$\begin{array}{l}\text { Private sector issues (excluding } \\
\text { privatizations) }\end{array}$} \\
\hline Market value 2/ & 125,013 & 208,567 & 120,960 & 127,405 & 116,629 \\
\hline \multirow[t]{2}{*}{ Volume of stock exchange trade $3 /$} & 54,226 & 118,764 & 92,467 & 30,397 & 25,617 \\
\hline & \multicolumn{5}{|c|}{ (In percent) } \\
\hline Annual turnover ratio 4/ & 0.60 & 0.75 & 0.64 & 0.26 & 0.23 \\
\hline \multicolumn{6}{|l|}{ Real overall rate of return 5 / } \\
\hline All shares & 71.5 & 27.0 & -45.2 & 4.3 & -13.0 \\
\hline
\end{tabular}

Sources: Data provided by the Bank of Israel; and Central Bureau of Statistics.

1/ Shares, convertible securities, and exercised options.

2/ End-of-year figures.

3/ Volume of trade on and off the floor.

4/ Ratio of monthly volume of trade (on and off the floor) to average monthly market value of the stock of shares.

5/ Deflated by end-of-month CPI. 
Table A26. Israel: Principal Bond Market Indicators, 1992-96

\begin{tabular}{|c|c|c|c|c|c|}
\hline & 1992 & 1993 & 1994 & 1995 & 1996 \\
\hline & \multicolumn{5}{|c|}{ (In millions of 1996 new sheqalim, unless otherwise indicated) } \\
\hline \multicolumn{6}{|l|}{ Market value of listed bonds } \\
\hline Government & 112,741 & 114,823 & 109,500 & 117,103 & 122,766 \\
\hline Corporate $1 /$ & 16,470 & 15,821 & 13,251 & 11,351 & 9,678 \\
\hline Total & 129,211 & 130,644 & 122,751 & 128,454 & 132,444 \\
\hline \multicolumn{6}{|l|}{ Of which: } \\
\hline \multicolumn{6}{|l|}{ Percentage held by: } \\
\hline Public & 27 & 28 & 26 & 25 & 31 \\
\hline Commercial banks & 19 & 19 & 21 & 27 & 28 \\
\hline Social insurance funds & 52 & 51 & 50 & 45 & 37 \\
\hline Bank of Israel & 2 & 2 & 2 & 3 & 4 \\
\hline \multicolumn{6}{|l|}{ Volume of stock exchange trade } \\
\hline Government & 17,496 & 20,155 & 16,881 & 17,678 & 26,003 \\
\hline Corporate 1/ & 1,812 & 1,180 & 1,406 & 1,005 & 757 \\
\hline Total & 19,308 & 21,335 & 18,287 & 18,683 & 26,760 \\
\hline \multicolumn{6}{|l|}{ Bank of Israel intervention $2 /$} \\
\hline (in percent) & 2.0 & 2.2 & 1.8 & 2.9 & 2.5 \\
\hline \multicolumn{6}{|c|}{$\begin{array}{l}\text { Net issues of tradable bonds (issues } \\
\text { less redemptions) }\end{array}$} \\
\hline Government & 4,856 & 1,884 & $-3,640$ & 5,971 & 1,685 \\
\hline Private $1 /$ & $-1,433$ & $-1,352$ & $-2,362$ & $-1,641$ & $-1,594$ \\
\hline Total & 3,423 & 532 & $-6,002$ & 4,330 & 91 \\
\hline \multicolumn{6}{|l|}{ Annual turnover 3/ } \\
\hline Government & 0.17 & 0.18 & 0.15 & 0.17 & $\ldots$ \\
\hline Private $1 /$ & 0.12 & 0.08 & 0.10 & 0.09 & $\ldots$ \\
\hline \multirow[t]{2}{*}{ Total } & 0.17 & 0.18 & 0.15 & 0.16 & $\ldots$ \\
\hline & \multicolumn{5}{|c|}{ (In percent) } \\
\hline \multicolumn{6}{|l|}{ Real overall rate of return } \\
\hline CPI-indexed bonds & 5.5 & -1.4 & -3.4 & 1.0 & 2.4 \\
\hline Exchange-rate indexed bonds & 18.9 & -4.3 & -10.4 & 1.1 & -0.4 \\
\hline Nominal bonds & $\ldots$ & 2.7 & -3.6 & 8.5 & 5.8 \\
\hline
\end{tabular}

Sources: Data provided by the Bank of Israel and Central Bureau of Statistics.

1/ Including public sector corporations.

2/ Ratio of the central bank's sales and purchases in the secondary market to total volume of stock exchange trade in bonds.

3/ Ratio of monthly volume of trade (on and off the floor) to market value of the stock of bonds.

Calculated from monthly ratios. 
Table A27. Israel: Institutional Investor Indicators, 1992-96

\begin{tabular}{|c|c|c|c|c|c|}
\hline & 1992 & 1993 & 1994 & 1995 & 1996 \\
\hline \multicolumn{6}{|l|}{ Mutual funds } \\
\hline Total assets (in 1996 NIS billions) & 43.8 & 49.8 & 23.1 & 17.5 & 12.7 \\
\hline Real growth rate of total assets (in percent) & 92.9 & 13.8 & -53.7 & -24.0 & -24.7 \\
\hline Real annual rate of return (in percent) & 27.9 & $\cdot 10.3$ & -29.0 & 2.8 & -9.7 \\
\hline \multicolumn{6}{|l|}{ Percent of total tradable assets: } \\
\hline CPI indexed bonds & 10 & 8 & 6 & 4 & 3 \\
\hline Foreign-currency indexed bonds & 37 & 32 & 17 & 11 & 9 \\
\hline Nonbank shares & 13 & 12. & 9 & 6 & 5 \\
\hline Unindexed assets & 10 & 9 & 3 & 3 & 3 \\
\hline \multicolumn{6}{|l|}{ Provident funds } \\
\hline Total assets (in 1996 NIS billions) & 129 & 134 & 126 & 122 & 109 \\
\hline Real growth rate of total assets (in percent) & 11.5 & 4.3 & -6.1 & -3.1 & -10.0 \\
\hline Real annual rate of return (in percent) & 11.3 & 2.7 & -8.3 & 2.5 & 1.5 \\
\hline \multicolumn{6}{|l|}{ Percent of total tradable assets: } \\
\hline Tradable government bonds & 51 & 51 & 51 & 48 & 43 \\
\hline Private bonds & 57 & 53 & 62 & 63 & 63 \\
\hline Nonbank shares & 10 & 9 & 12 & 11 & 9 \\
\hline Unindexed assets & 9 & 7 & 7 & 6 & 5 \\
\hline \multicolumn{6}{|l|}{ Pension funds } \\
\hline Total assets (in 1996 NIS billions) & 63 & 67 & 70 & 74 & 78 \\
\hline Real growth rate of total assets (in percent) & 4.1 & 5.5 & 4.7 & 6.4 & 4.2 \\
\hline Real annual rate of return (in percent) & 4.9 & 5.1 & 5.1 & 5.1 & 5.1 \\
\hline
\end{tabular}

Sources: Data provided by the Bank of Israel; and Central Bureau of Statistics. 
Table A28. Israel: State Budget Balance and Financing, 1992-98

\begin{tabular}{|c|c|c|c|c|c|c|c|c|}
\hline & \multirow{3}{*}{1992} & \multirow[t]{3}{*}{1993} & \multirow{3}{*}{1994} & \multirow[t]{3}{*}{1995} & \multirow[t]{3}{*}{1996} & \multicolumn{2}{|c|}{1997} & \multirow{3}{*}{1998} \\
\hline & & & & & & & Estimated & \\
\hline & & & & & & Budget & Outturn & \\
\hline & \multicolumn{8}{|c|}{ (In millions of new sheqalim) } \\
\hline Total revenue (excluding foreign grants) & 62,858 & 73,018 & 90,120 & 104,469 & 116,648 & 139,363 & 133,946 & 148,588 \\
\hline Total expenditure & 78,073 & 85,861 & 103,411 & 120,516 & 141,099 & 159,801 & 153,801 & 168,850 \\
\hline Budget balance before foreign grants & $-15,215$ & $-12,843$ & $-13,291$ & $-16,047$ & $-24,451$ & $-20,438$ & $-19,855$ & $-20,262$ \\
\hline Foreign grants & 9,063 & 8,232 & 8,018 & 5,126 & 12,985 & 10,695 & 10,390 & 11,070 \\
\hline Budget balance after foreign grants & $-6,152$ & $-4,611$ & $-5,273$ & $-10,921$ & $-11,466$ & $-9,743$ & $-9,465$ & $-9,192$ \\
\hline Total financing & 6,152 & 4,611 & 5,273 & 10,921 & 11,466 & 9,743 & 9,465 & 9,192 \\
\hline Foreign (net) & 1,967 & 1,157 & 86 & 3,912 & 3,450 & 2,785 & $\ldots$ & 2,000 \\
\hline Gross & 5,145 & 5,248 & 5,489 & 9,397 & 9,486 & 11,550 & $\ldots$ & 9,980 \\
\hline Repayment & 3,178 & 4,091 & 5,403 & 5,485 & 6,036 & 8,765 & $\ldots$ & 7,980 \\
\hline Domestic (net) & 4,185 & 3,454 & 5,187 & 7,009 & 8,016 & 6,958 & $\ldots$ & 7,192 \\
\hline Nonbank borrowing (net) & 5,582 & 2,652 & -323 & 6,440 & 7,923 & 3,189 & $\ldots$ & 1,983 \\
\hline Gross & 18,745 & 14,335 & 20,358 & 24,206 & 34,006 & 28,700 & $\ldots$ & 34,463 \\
\hline Repayment & 13,163 & 11,683 & 20,681 & 17,766 & 26,083 & 25,511 & $\ldots$ & 32,480 \\
\hline Bank of Israel credit (net) & -218 & 140 & 4,242 & $-1,405$ & 765 & 0 & $\ldots$ & 0 \\
\hline Sale of assets & 1,202 & 3,254 & 703 & 1,798 & 349 & 4,300 & $\ldots$ & 4,300 \\
\hline Lending (net) (-) & $-2,277$ & $-2,589$ & 564 & 181 & -807 & -629 & $\ldots$ & 809 \\
\hline Gross (-) & $-4,686$ & $-5,523$ & $-2,825$ & $-3,555$ & $-4,507$ & $-5,129$ & $\ldots$ & $-4,491$ \\
\hline Of which: housing (-) & $-2,631$ & $-2,856$ & $-2,334$ & $-2,797$ & 3,264 & $-3,999$ & $\ldots$ & 3,584 \\
\hline Repayment & 2,409 & 2,934 & 3,389 & 3,736 & 3,699 & 4,500 & $\ldots$ & 5,300 \\
\hline Residual & -104 & -3 & 1 & -5 & 0 & 99 & $\ldots$ & 100 \\
\hline \multicolumn{9}{|l|}{ Memorandum items: } \\
\hline Primary balance & 4,779 & 8,208 & 8,731 & 4,738 & 6,472 & 9,893 & $\ldots$ & 11,428 \\
\hline Current balance & 1,188 & 1,440 & 932 & $-4,635$ & $-3,989$ & 2,725 & $\ldots$ & 3,765 \\
\hline Domestic balance & $-7,954$ & $-4,360$ & $-4,372$ & $-8,529$ & $-13,952$ & $-6,860$ & $\ldots$ & $-8,405$ \\
\hline Foreign balance & 1,802 & -251 & -901 & $-2,392$ & 2,486 & $-2,883$ & $\ldots$ & -787 \\
\hline \multirow[t]{2}{*}{ Nominal GDP } & 160,770 & 184,918 & 223,185 & 261,173 & 303,812 & 346,429 & 336,538 & 376,810 \\
\hline & \multicolumn{8}{|c|}{ (In percent of GDP) } \\
\hline Total revenue (excluding foreign grants) & 39.1 & 39.5 & 40.4 & 40.0 & 38.4 & 40.2 & 39.8 & 39.4 \\
\hline Total expenditure & 48.6 & 46.4 & 46.3 & 46.1 & 46.4 & 46.1 & 45.7 & 44.8 \\
\hline Budget balance before foreign grants & -9.5 & -6.9 & -6.0 & -6.1 & -8.0 & -5.9 & -5.9 & -5.4 \\
\hline Foreign grants & 5.6 & 4.5 & 3.6 & 2.0 & 4.3 & 3.1 & 3.1 & 2.9 \\
\hline Budget balance after foreign grants & -3.8 & -2.5 & -2.4 & -4.2 & -3.8 & -2.8 & -2.8 & -2.4 \\
\hline Total financing & 3.8 & 2.5 & 2.4 & 4.2 & 3.8 & 2.8 & 2.8 & 2.4 \\
\hline Foreign (net) & 1.2 & 0.6 & 0.0 & 1.5 & 1.1 & 0.8 & $\ldots$ & 0.5 \\
\hline Gross & 3.2 & 2.8 & 2.5 & 3.6 & 3.1 & 3.3 & $\ldots$ & 2.6 \\
\hline Repayment & 2.0 & 2.2 & 2.4 & 2.1 & 2.0 & 2.5 & $\ldots$ & 2.1 \\
\hline Domestic (net) & 2.6 & 1.9 & 2.3 & 2.7 & 2.6 & 2.0 & $\ldots$ & 1.9 \\
\hline Nonbank borrowing (net) & 3.5 & 1.4 & -0.1 & 2.5 & 2.6 & 0.9 & $\ldots$ & 0.5 \\
\hline Gross & 11.7 & 7.8 & 9.1 & 9.3 & 11.2 & 8.3 & $\ldots$ & 9.1 \\
\hline Repayment & 8.2 & 6.3 & 9.3 & 6.8 & 8.6 & 7.4 & $\ldots$ & 8.6 \\
\hline Bank of Israel credit (net) & -0.1 & 0.1 & 1.9 & -0.5 & 0.3 & 0.0 & $\ldots$ & 0.0 \\
\hline Sale of assets & 0.7 & 1.8 & 0.3 & 0.7 & 0.1 & 1.2 & $\ldots$ & 1.1 \\
\hline Lending (nct) $(-)$ & -1.4 & -1.4 & 0.3 & 0.1 & -0.3 & -0.2 & $\ldots$ & 0.2 \\
\hline Gross (-) & -2.9 & -3.0 & -1.3 & -1.4 & -1.5 & -1.5 & $\ldots$ & -1.2 \\
\hline Of which: housing (-) & -1.6 & -1.5 & -1.0 & -1.1 & 1.1 & -1.2 & $\ldots$ & 1.0 \\
\hline Repayment & 1.5 & 1.6 & 1.5 & 1.4 & 1.2 & 1.3 & $\ldots$ & 1.4 \\
\hline \multicolumn{9}{|l|}{ Memorandum items: } \\
\hline Primary balance & 3.0 & 4.4 & 3.9 & 1.8 & 2.1 & 2.9 & $\ldots$ & 3.0 \\
\hline Current balance & 0.7 & 0.8 & 0.4 & -1.8 & -1.3 & 0.8 & $\ldots$ & 1.0 \\
\hline Domestic balance & -4.9 & -2.4 & -2.0 & -3.3 & -4.6 & -2.0 & $\ldots$ & -2.2 \\
\hline Foreign balance & 1.1 & -0.1 & -0.4 & -0.9 & 0.8 & -0.8 & $\ldots$ & -0.2 \\
\hline
\end{tabular}


Table A29. Israel: State Budget Revenue, 1992-98

\begin{tabular}{|c|c|c|c|c|c|c|c|c|}
\hline & \multirow[t]{3}{*}{1992} & \multirow[t]{3}{*}{1993} & \multirow[t]{3}{*}{1994} & \multirow[t]{3}{*}{1995} & \multirow[t]{3}{*}{1996} & \multicolumn{2}{|c|}{1997} & \multirow{3}{*}{$\begin{array}{l}1998 \\
\text { Budget }\end{array}$} \\
\hline & & & & & & & Estínated & \\
\hline & & & & & & Budget & Outturn & \\
\hline & \multicolumn{8}{|c|}{ (In millions of new sheqalim) } \\
\hline Total tax revenue & 50,565 & 59,186 & 72,650 & 82,651 & 93,941 & 111,365 & 107,120 & 121,100 \\
\hline Taxes on income and profits & 20,453 & 25,730 & 33,302 & 37,892 & 42,421 & 51,290 & 51,150 & 58,070 \\
\hline Companies & 4,577 & 6,113 & 9,121 & 9,158 & 9,597 & 12,030 & 12,500 & $\ldots$ \\
\hline Individuals & 15,876 & 19,617 & 24,181 & 28,734 & 32,824 & 39,260 & 38,650 & $\ldots$ \\
\hline Wage \& salary & 11,987 & 14,909 & 18,691 & 22,241 & 26,175 & 31,480 & 31,150 & $\ldots$ \\
\hline Self-employed & 3,889 & 4,708 & 5,490 & 6,493 & 6,649 & 7,780 & 7,500 & $\ldots$ \\
\hline Payroll tax (nonprofit) & 752 & 592 & 697 & 914 & 1,265 & 1,500 & 1,400 & 1,560 \\
\hline Taxes on property & 1,338 & 2,087 & 3,299 & 3,510 & 3,634 & 3,860 & 3,000 & 3,440 \\
\hline Real-estate purchase tax & 603 & 1,002 & 1,474 & 1,505 & 1,574 & 1,840 & 1,200 & 1,350 \\
\hline Land betterment tax & 369 & 669 & 1,136 & 1,227 & 1,149 & 1,220 & 1,050 & 1,180 \\
\hline Property tax & 366 & 416 & 689 & 778 & 911 & 800 & 750 & 910 \\
\hline Taxes on goods and services & 27,914 & 30,482 & 35,604 & 41,057 & 46,885 & 54,715 & 51,570 & 58,030 \\
\hline VAT & 18,518 & 20,334 & 24,313 & 28,822 & 32,506 & 37,725 & 35,760 & 40,440 \\
\hline Domestic expenditure $\&$ civilian imports & 15,481 & 17,080 & 20,567 & 24,217 & 27,872 & 32,540 & 30,750 & $\ldots$ \\
\hline Nonprofit entities & 1,862 & 2,011 & 2,634 & 3,310 & 2,865 & 3,340 & 3,200 & $\ldots$ \\
\hline Financial institutions & 551 & 594 & 687 & 836 & 874 & 1,040 & 1,010 & $\ldots$ \\
\hline Defense imports & 624 & 649 & 425 & 459 & 895 & 805 & 800 & $\ldots$ \\
\hline Excises & 3,002 & 3,444 & 3,821 & 4,196 & 5,647 & 6,990 & 6,610 & 7,430 \\
\hline Fuel & 2,213 & 2,427 & 2,715 & 3,110 & 4,159 & 5,280 & 5,000 & 5,620 \\
\hline Tobacco & 458 & 541 & 565 & 586 & 737 & 890 & 850 & 950 \\
\hline Stamp & 331 & 476 & 541 & 500 & 751 & 820 & 760 & 860 \\
\hline Purchase tax & 4,772 & 5,553 & 6,625 & 7,069 & 7,672 & 8,820 & 8,000 & 8,850 \\
\hline Domestic & 654 & 676 & 654 & $705^{\circ}$ & 718 & 820 & 800 & $\ldots$ \\
\hline Imports & 4,118 & 4,877 & 5,970 & 6,364 & 6,954 & 8,000 & 7,200 & $\ldots$ \\
\hline Customs duties & 1,622 & 1,151 & 845 & 970 & 1,060 & 1,180 & 1,200 & 1,310 \\
\hline Adjustment to budget frame & 108 & 295 & -252 & -722 & -264 & 0 & 0 & 0 \\
\hline Total nontax revenue & 12,293 & 13,832 & 17,470 & 21,818 & 22,707 & 27,998 & 26,826 & 27,488 \\
\hline Interest & 1,482 & 1,374 & 1,709 & 2,914 & 2,465 & 2,840 & $\ldots$ & 3,180 \\
\hline Domestic & 1,399 & 1,231 & 1,528 & 1,973 & 2,224 & 2,450 & $\ldots$ & 2,750 \\
\hline Foreign & 83 & 143 & 181 & 941 & 241 & 390 & $\ldots$ & 430 \\
\hline Loans from National Insurance Institute & 3,250 & 3,100 & 4,750 & 4,965 & 5,370 & 6,872 & $\ldots$ & 6,600 \\
\hline Fees, royalties, pension provisions, \& misc. & 3,168 & 2,853 & 3,011 & 4,875 & 5,618 & 6,064 & $\ldots$ & 8,570 \\
\hline Income from Israel Land Administration & 463 & 1,000 & 1,808 & 1,643 & 1,715 & 1,510 & $\ldots$ & 1,215 \\
\hline Revenue for revenue-dependent expenditure & 3,930 & 5,505 & 6,192 & 7,421 & 7,539 & 10,712 & $\ldots$ & 7,923 \\
\hline Total revenue & 62,858 & 73,018 & 90,120 & 104,469 & 116,648 & 139,363 & 133,946 & 148,588 \\
\hline Foreign grants & 9,063 & 8,232 & 8,018 & 5,126 & 12,985 & 10,695 & 10,390 & 11,070 \\
\hline Total revenue and grants & 71,921 & 81,250 & 98,138 & 109,595 & 129,633 & 150,058 & 144,336 & 159,658 \\
\hline \multicolumn{9}{|l|}{ Memorandum items: } \\
\hline Domestic revenue & 61,012 & 71,944 & 89,079 & 101,923 & 113,749 & 138,264 & $\ldots$ & 145,092 \\
\hline Foreign revenue and grants & 10,909 & 9,306 & 9,059 & 7,672 & 15,884 & 11,794 & $\ldots$ & 14,566 \\
\hline Nominal GDP & 160,770 & 184,918 & 223,185 & 261,173 & 303,812 & 346,429 & 336,538 & 376,810 \\
\hline & \multicolumn{8}{|c|}{ (In percent of GDP) } \\
\hline Total tax revenue & 31.5 & 32.0 & 32.6 & 31.6 & 30.9 & 32.1 & 31.8 & 32.1 \\
\hline Taxes on income and profits & 12.7 & 13.9 & 14.9 & 14.5 & 14.0 & 14.8 & 15.2 & 15.4 \\
\hline Companies & 2.8 & 3.3 & 4.1 & 3.5 & 3.2 & 3.5 & 3.7 & 0.0 \\
\hline Individuals & 9.9 & 10.6 & 10.8 & 11.0 & 10.8 & 11.3 & 11.5 & 0.0 \\
\hline Payroll tax (nonprofit) & 0.5 & 0.3 & 0.3 & 0.3 & 0.4 & 0.4 & 0.4 & 0.4 \\
\hline Taxes on property & 0.8 & 1.1 & 1.5 & 1.3 & 1.2 & 1.1 & 0.9 & 0.9 \\
\hline Taxes on goods and services & 17.4 & 16.5 & 16.0 & 15.7 & 15.4 & 15.8 & 15.3 & 15.4 \\
\hline VAT & 11.5 & 11.0 & 10.9 & $11.0^{\circ}$ & 10.7 & 10.9 & 10.6 & 10.7 \\
\hline Excises & 1.9 & 1.9 & 1.7 & 1.6 & 1.9 & 2.0 & 2.0 & 2.0 \\
\hline Purchase tax & 3.0 & 3.0 & 3.0 & 2.7 & 2.5 & 2.5 & 2.4 & 2.3 \\
\hline Customs duties & 1.0 & 0.6 & 0.4 & 0.4 & 0.3 & 0.3 & 0.4 & 0.3 \\
\hline Adjustment to budget frame & 0.1 & 0.2 & -0.1 & -0.3 & -0.1 & 0.0 & 0.0 & 0.0 \\
\hline Total nontax revenue & 7.6 & 7.5 & 7.8 & 8.4 & 7.5 & 8.1 & 8.0 & 7.3 \\
\hline Total revenue & 39.1 & 39.5 & 40.4 & 40.0 & 38.4 & 40.2 & 39.8 & 39.4 \\
\hline Foreign grants & 5.6 & 4.5 & 3.6 & 2.0 & 4.3 & 3.1 & 3.1 & 2.9 \\
\hline Total revenue and grants & 44.7 & 43.9 & 44.0 & 42.0 & 42.7 & 43.3 & 42.9 & 42.4 \\
\hline \multicolumn{9}{|l|}{ Memorandum items: } \\
\hline Domestic revenue & 37.9 & 38.9 & 39.9 & 39.0 & 37.4 & 39.9 & $\ldots$ & 38.5 \\
\hline Foreign revenue and grants & 6.8 & 5.0 & 4.1 & 2.9 & 5.2 & 3.4 & $\ldots$ & 3.9 \\
\hline
\end{tabular}


Table A30. Israel: State Budget Expenditure (Economic Classification), 1992-98

\begin{tabular}{|c|c|c|c|c|c|c|c|c|}
\hline & \multirow{3}{*}{1992} & \multirow{3}{*}{1993} & \multirow{3}{*}{1994} & \multirow{3}{*}{1995} & \multirow{3}{*}{1996} & \multicolumn{2}{|c|}{1997} & \multirow{3}{*}{1998} \\
\hline & & & & & & \multicolumn{2}{|r|}{ Estimated } & \\
\hline & & & & & & Budget & Outturn & \\
\hline & \multicolumn{8}{|c|}{ (In millions of new sheqalim) } \\
\hline Current expenditure & 70,733 & 79,810 & 97,206 & 114,230 & 133,622 & 147,333 & $\ldots$ & 155,894 \\
\hline Wages & 14,462 & 16,054 & 20,937 & 25,494 & 29,576 & 33,409 & $\ldots$ & 33,370 \\
\hline Of which: Defense & 6,100 & 6,372 & 8,036 & 9,475 & 10,629 & 11,817 & $\ldots$ & 12,645 \\
\hline Goods and services & 16,618 & 17,728 & 21,641 & 24,873 & 28,685 & 29,007 & $\ldots$ & 31,042 \\
\hline Of which: Defense & 11,090 & 11,423 & 13,332 & 15,530 & 17,369 & 17,967 & $\ldots$ & 19,715 \\
\hline Interest & 12,413 & 14,193 & 15,713 & 18,573 & 20,403 & 22,476 & $\cdots$ & 23,800 \\
\hline Domestic & 8,811 & 10,063 & 11,098 & 13,739 & 14,425 & 16,527 & $\cdots$ & 17,640 \\
\hline Foreign & 3,602 & 4,130 & 4,615 & 4,834 & 5,978 & 5,949 & $\cdots$ & 6,160 \\
\hline Subsidies and transfers & 25,852 & 30,050 & 36,579 & 42,471 & 51,729 & 58,559 & $\ldots$ & 63,202 \\
\hline Subsidies & 4,010 & 4,484 & 4,595 & 4,982 & 5,156 & 5,733 & $\ldots$ & 5,950 \\
\hline Nonexport & 819 & 1,125 & 1,524 & 1,572 & 1,771 & 1,766 & $\ldots$ & 1,966 \\
\hline Export & 675 & 409 & 86 & 0 & 0 & 0 & $\ldots$ & 0 \\
\hline Investment grants & 2,516 & 2,950 & 2,985 & 3,410 & 3,385 & 3,967 & $\ldots$ & 3,985 \\
\hline Transfers & 21,842 & 25,566 & 31,984 & 37,489 & 46,572 & 52,826 & $\ldots$ & 57,252 \\
\hline To local authorities & 2,791 & 3,276 & 4,605 & 5,780 & 7,072 & 7,843 & $\ldots$ & 9,053 \\
\hline To National Insurance Institute & 8,139 & 9,680 & 12,711 & 15,260 & & $\ldots$ & $\ldots$ & $\ldots$ \\
\hline To nonprofit institutions & 9,625 & 11,269 & 13,168 & 14,678 & & $\ldots$ & $\ldots$ & ... \\
\hline To defense & 1,287 & 1,341 & 1,500 & 1,771 & 1,980 & 2,400 & $\ldots$ & 2,555 \\
\hline Repayment to National Insurance Institute & 1,388 & 1,785 & 2,336 & 2,819 & 3,230 & 3,882 & $\ldots$ & 4,480 \\
\hline Capital expenditure & 7,340 & 6,266 & 6,205 & 6,286 & 7,477 & 8,687 & $\ldots$ & 8,736 \\
\hline Of which: Housing & 5,310 & 2,691 & 1,863 & 1,843 & 2,139 & 2,356 & $\ldots$ & 2,205 \\
\hline Reserve & 0 & -215 & 0 & 0 & 0 & 3,781 & $\ldots$ & 4,220 \\
\hline Total expenditure & 78,073 & 85,861 & 103,411 & 120,516 & 141,099 & 159,801 & 153,801 & 168,850 \\
\hline \multicolumn{9}{|l|}{ Memorandum items: } \\
\hline Domestic expenditure & 68,966 & 76,304 & 93,451 & 110,452 & 127,701 & 145,124 & $\ldots$ & 153,498 \\
\hline Foreign expenditure & 9,107 & 9,557 & 9,960 & 10,064 & 13,398 & 14,677 & $\ldots$ & 15,353 \\
\hline \multirow[t]{2}{*}{ Nominal GDP } & 160,770 & 184,918 & 223,185 & 261,173 & 303,812 & 346,429 & 336,538 & 376,810 \\
\hline & \multicolumn{8}{|c|}{ (In percent of GDP) } \\
\hline Current expenditure & 44.0 & 43.2 & 43.6 & 43.7 & 44.0 & 42.5 & $\ldots$ & 41.4 \\
\hline Wages & 9.0 & 8.7 & 9.4 & 9.8 & 9.7 & 9.6 & $\ldots$ & 8.9 \\
\hline Goods and services & 10.3 & 9.6 & 9.7 & 9.5 & 9.4 & 8.4 & $\ldots$ & 8.2 \\
\hline Interest & 7.7 & 7.7 & 7.0 & 7.1 & 6.7 & 6.5 & $\ldots$ & 6.3 \\
\hline Domestic & 5.5 & 5.4 & 5.0 & 5.3 & 4.7 & 4.8 & $\ldots$ & 4.7 \\
\hline Foreign & 2.2 & 2.2 & 2.1 & 1.9 & 2.0 & 1.7 & $\ldots$ & 1.6 \\
\hline Subsidies and transfers & 16.1 & 16.3 & 16.4 & 16.3 & 17.0 & 16.9 & $\ldots$ & 16.8 \\
\hline Repayment to National Insurance Institute & 0.9 & 1.0 & 1.0 & 1.1 & 1.1 & 1.1 & $\ldots$ & 1.2 \\
\hline Capital expenditure & 4.6 & 3.4 & 2.8 & 2.4 & 2.5 & 2.5 & $\ldots$ & 2.3 \\
\hline Of which: Housing & 3.3 & 1.5 & 0.8 & 0.7 & 0.7 & 0.7 & $\ldots$ & 0.6 \\
\hline Reserve & 0.0 & -0.1 & 0.0 & 0.0 & 0.0 & 1.1 & $\ldots$ & 1.1 \\
\hline Total expenditure & 48.6 & 46.4 & 46.3 & 46.1 & 46.4 & 46.1 & 45.7 & 44.8 \\
\hline \multicolumn{9}{|l|}{ Memorandum items: } \\
\hline Domestic expenditure & 42.9 & 41.3 & 41.9 & 42.3 & 42.0 & 41.9 & $\ldots$ & 40.7 \\
\hline Foreign expenditure & 5.7 & 5.2 & 4.5 & 3.9 & 4.4 & 4.2 & $\ldots$ & 4.1 \\
\hline
\end{tabular}

Sources: Data provided by the Ministry of Finance; and staff estimates. 
Table A31. Israel: State Budget Expenditure (Functional Classification), 1992-98

\begin{tabular}{|c|c|c|c|c|c|c|c|c|}
\hline \multirow[b]{2}{*}{ - } & \multirow[t]{2}{*}{1992} & \multirow[t]{2}{*}{1993} & \multirow[t]{2}{*}{1994} & \multirow[t]{2}{*}{1995} & \multirow[t]{2}{*}{1996} & \multicolumn{2}{|c|}{1997} & \multirow{2}{*}{1998} \\
\hline & & & & & & Budget & $\begin{array}{l}\text { Estimated } \\
\text { Outturn }\end{array}$ & \\
\hline & \multicolumn{8}{|c|}{ (In millions of new sheqalim) } \\
\hline General public service & 5,179 & 5,973 & 7,594 & 9,657 & 11,763 & 13,426 & $\ldots$ & 14,982 \\
\hline General administration & 3,592 & 4,100 & 5,135 & 6,626 & 8,242 & 9,514 & $\ldots$ & 10,722 \\
\hline Public order & 1,587 & 1,873 & 2,459 & 3,031 & 3,521 & 3,912 & $\ldots$ & 4,260 \\
\hline Defense & 18,618 & 19,286 & 22,050 & 26,926 & 30,852 & 32,297 & $\ldots$ & 34,793 \\
\hline Education & 8,218 & 10,017 & 13,564 & 15,661 & 20,211 & 23,339 & $\ldots$ & 25,508 \\
\hline Of which: Universities & 1,524 & 1,691 & 2,383 & 2,747 & 3,649 & 4,056 & $\ldots$ & 4,501 \\
\hline Health & 3,336 & 3,727 & 6,146 & 6,828 & 8,802 & 15,204 & $\ldots$ & 13,097 \\
\hline Labor and welfare & 10,036 & 11,945 & 15,469 & 18,636 & 21,891 & 18,709 & $\ldots$ & 19,905 \\
\hline Other social services & 13,008 & 11,690 & 10,056 & 10,707 & 11,769 & 13,539 & $\ldots$ & 13,063 \\
\hline Of which: Housing & 10,959 & 9,721 & 7,898 & 8,173 & 9,226 & 10,646 & $\ldots$ & 9,895 \\
\hline Immigrant absorption & 1,351 & 1,147 & 1,244 & - 1,241 & 1,377 & 1,567 & $\ldots$ & 1,616 \\
\hline Economic services & 6,246 & 8,375 & 7,289 & 8,717 & 9,792 & 11,157 & $\ldots$ & 11,522 \\
\hline General & 246 & 384 & 545 & 698 & 731 & 807 & $\ldots$ & 700 \\
\hline Agricultural & 2,538 & 2,860 & 732 & 971 & 1,399 & 1,171 & $\ldots$ & 1,286 \\
\hline Manufacturing & 1,473 & 2,016 & 2,460 & 3,075 & 3,290 & 3,738 & $\ldots$ & 3,948 \\
\hline Water and energy & 604 & 679 & 772 & 824 & 726 & 1,187 & $\ldots$ & 1,205 \\
\hline Transport and communications & 968 & 1,553 & 1,960 & 2,025 & 2,181 & 2,158 & $\ldots$ & 2,452 \\
\hline Other & 417 & 883 & 821 & 1,124 & 1,465 & 2,096 & $\ldots$ & 1,931 \\
\hline Unallocable and other functions & 14,326 & 15,439 & 17,713 & 20,392 & 22,980 & 27,718 & $\ldots$ & 29,789 \\
\hline Interest & 12,414 & 14,193 & 15,910 & 18,574 & 20,403 & 22,476 & $\ldots$ & 23,800 \\
\hline Interest and loan subsidy & 536 & 472 & 420 & 365 & 297 & 186 & $\ldots$ & 278 \\
\hline Subsidy for basic products & 1,254 & 1,495 & 1,725 & 1,633 & 1,839 & 1,962 & $\ldots$ & 2,059 \\
\hline Export market development & 675 & 410 & 86 & 0 & 0 & 0 & $\ldots$ & 0 \\
\hline General transfers & 1,856 & 2,018 & 2,961 & 3,556 & 4,142 & 3,812 & $\ldots$ & 4,732 \\
\hline Reserves & 0 & -215 & 0 & 0 & 0 & 3,781 & $\ldots$ & 4,220 \\
\hline Repayment of loans (-) & $-2,409$ & $-2,934$ & $-3,389$ & $-3,736$ & $-3,699$ & $-4,500$ & $\ldots$ & $-5,300$ \\
\hline Adjustment to total expenditure (excluding net lending) & $-3,303$ & $-3,525$ & 141 & -744 & -659 & -88 & $\ldots$ & 893 \\
\hline \multirow[t]{2}{*}{ Total expenditure and net lending } & 78,967 & 86,452 & 99,881 & 117,524 & 138,059 & 155,389 & $\ldots$ & 162,657 \\
\hline & \multicolumn{7}{|c|}{ (Percent of GDP) } & \\
\hline General public service & 3.2 & 3.2 & 3.4 & 3.7 & 3.9 & 3.9 & $\ldots$ & 4.0 \\
\hline Defense & 11.6 & 10.4 & 9.9 & 10.3 & 10.2 & 9.3 & $\ldots$ & 9.2 \\
\hline Education & 5.1 & 5.4 & 6.1 & 6.0 & 6.7 & 6.7 & $\ldots$ & 6.8 \\
\hline Health & 2.1 & 2.0 & 2.8 & 2.6 & 2.9 & 4.4 & $\ldots$ & 3.5 \\
\hline Labor and welfare & 6.2 & 6.5 & 6.9 & 7.1 & 7.2 & 5.4 & $\ldots$ & 5.3 \\
\hline Other social services & 8.1 & 6.3 & 4.5 & 4.1 & 3.9 & 3.9 & $\ldots$ & 3.5 \\
\hline Of which: Housing & 6.8 & 5.3 & 3.5 & 3.1 & 3.0 & 3.1 & $\ldots$ & 2.6 \\
\hline Immigrant absorption & 0.8 & 0.6 & 0.6 & 0.5 & 0.5 & 0.5 & $\ldots$ & 0.4 \\
\hline Economic services & 3.9 & 4.5 & 3.3 & 3.3 & 3.2 & 3.2 & $\ldots$ & 3.1 \\
\hline Unallocable and other functions & 8.9 & 8.3 & 7.9 & 7.8 & 7.6 & 8.0 & $\ldots$ & 7.9 \\
\hline Interest & 7.7 & 7.7 & 7.1 & 7.1 & 6.7 & 6.5 & $\ldots$ & 6.3 \\
\hline Interest and loan subsidy & 0.3 & 0.3 & 0.2 & 0.1 & 0.1 & 0.1 & $\ldots$ & 0.1 \\
\hline Subsidy for basic products & 0.8 & 0.8 & 0.8 & 0.6 & 0.6 & 0.6 & $\ldots$ & 0.5 \\
\hline Export market development & 0.4 & 0.2 & 0.0 & 0.0 & 0.0 & 0.0 & $\ldots$ & 0.0 \\
\hline General transfers & 1.2 & 1.1 & 1.3 & 1.4 & 1.4 & 1.1 & $\ldots$ & 1.3 \\
\hline Reserves & 0.0 & -0.1 & 0.0 & 0.0 & 0.0 & 1.1 & $\ldots$ & 1.1 \\
\hline Repayment of loans $(-)$ & -1.5 & -1.6 & -1.5 & -1.4 & -1.2 & -1.3 & $\ldots$ & -1.4 \\
\hline Adjustment to total expenditure (excluding net lending) & -2.1 & -1.9 & 0.1 & -0.3 & .0 .2 & 0.0 & $\ldots$ & 0.2 \\
\hline Total expenditure and net lending & 49.1 & 46.8 & 44.8 & 45.0 & 45.4 & 44.9 & $\ldots$ & 43.2 \\
\hline
\end{tabular}


Table A32. Israel: General Government Balance and Financing (National Accounts), 1992-96

\begin{tabular}{|c|c|c|c|c|c|}
\hline & 1992 & 1993 & 1994 & 1995 & 1996 \\
\hline & \multicolumn{5}{|c|}{ (In millions of new sheqalim) } \\
\hline Total receipts (including foreign receipts) & 85,416 & 97,704 & 115,721 & 135,290 & 154,271 \\
\hline Total expenditure (including foreign expenditure) & 91,854 & 104,187 & 120,646 & 144,104 & 166,858 \\
\hline Overall balance & $-6,438$ & $-6,483$ & $-4,925$ & $-8,814$ & $-12,587$ \\
\hline Total financing & 6,438 & 6,483 & 4,925 & 8,814 & 12,587 \\
\hline Change in monetary base & 793 & 1,838 & 1,987 & -772 & 3,600 \\
\hline Foreign borrowing (net) & 3,014 & $-4,780$ & 7,286 & $-8,232$ & $-4,500$ \\
\hline Domestic borrowing (net) & $-4,124$ & 0 & -662 & 16,206 & 14,700 \\
\hline Through government (net) & 1,586 & 1,287 & 442 & 7,460 & 7,500 \\
\hline Through Bank of Israel (net) & $-5,710$ & $-1,287$ & $-1,104$ & 8,746 & 7,200 \\
\hline Sale of assets & 1,269 & 3,125 & 662 & 1,029 & 300 \\
\hline Residual 1/ & 5,486 & 6,299 & $-4,348$ & 582 & $-1,513$ \\
\hline \multicolumn{6}{|l|}{ Memorandum items: } \\
\hline Current balance (net saving) & $-1,356$ & $-2,463$ & $-1,934$ & $-5,378$ & $-9,494$ \\
\hline Current balance + depreciation (gross saving) & 972 & 145 & 984 & $-1,965$ & $-5,706$ \\
\hline Domestic balance & $-11,709$ & $-9,507$ & $-7,118$ & $-11,399$ & $-15,681$ \\
\hline Foreign balance & 5,271 & 3,024 & 2,193 & 2,585 & 3,094 \\
\hline & \multicolumn{5}{|c|}{ (In percent of GDP) } \\
\hline Total receipts (including foreign receipts) & 53.1 & 52.8 & 51.8 & 51.8 & 50.8 \\
\hline Total expenditure (including foreign expenditure) & 57.1 & 56.3 & 54.1 & 55.2 & 54.9 \\
\hline Overall balance & -4.0 & -3.5 & -2.2 & -3.4 & -4.1 \\
\hline Total financing & 4.0 & 3.5 & 2.2 & 3.4 & 4.1 \\
\hline Change in monetary base & 0.5 & 1.0 & 0.9 & -0.3 & 1.2 \\
\hline Foreign borrowing (net) & 1.9 & -2.6 & 3.3 & -3.2 & -1.5 \\
\hline Domestic borrowing (net) & -2.6 & 0.0 & -0.3 & 6.2 & 4.8 \\
\hline Through government (net) & 1.0 & 0.7 & 0.2 & 2.9 & 2.5 \\
\hline Through Bank of Israel (net) & -3.6 & -0.7 & -0.5 & 3.3 & 2.4 \\
\hline Sale of assets & 0.8 & 1.7 & 0.3 & 0.4 & 0.1 \\
\hline Residual & 3.4 & 3.4 & -1.9 & 0.2 & -0.5 \\
\hline \multicolumn{6}{|l|}{ Memorandum items: } \\
\hline Current balance (net saving) & -0.8 & -1.3 & -0.9 & -2.1 & -3.1 \\
\hline Current balance + depreciation (gross saving) & 0.6 & 0.1 & 0.4 & -0.8 & -1.9 \\
\hline Domestic balance & -7.3 & -5.1 & -3.2 & -4.4 & -5.2 \\
\hline Foreign balance & 3.3 & 1.6 & 1.0 & 1.0 & 1.0 \\
\hline
\end{tabular}

Source: Bank of Israel, Annual Report 1996.

1/ The deficit is calculated on the basis of flows rather than on a cash basis, so there are timing discrepancies between certain items. The financing of the deficit relates to the central government and not the rest of the public sector. 
Table A33. Israel: General Government Receipts (National Accounts), 1992-96

\begin{tabular}{|c|c|c|c|c|c|}
\hline & 1992 & 1993 & 1994 & 1995 & 1996 \\
\hline & \multicolumn{5}{|c|}{ (In percent of GDP) } \\
\hline Total domestic receipts & 45.3 & 45.8 & 46.5 & 46.9 & 45.9 \\
\hline Current receipts & 41.5 & 41.3 & 42.1 & 43.1 & 41.8 \\
\hline Taxes and fees & 38.6 & 38.8 & 39.5 & 40.1 & 38.9 \\
\hline Indirect taxes & 21.1 & 20.0 & 19.4 & 19.6 & 19.3 \\
\hline Domestic production & 14.9 & 14.2 & 13.9 & 14.1 & 14.1 \\
\hline Civilian imports & 6.1 & 5.8 & 5.6 & 5.5 & 5.2 \\
\hline Direct taxes and fees & 12.9 & 14.1 & 15.3 & 14.8 & 13.9 \\
\hline National insurance income $1 /$ & 4.6 & 4.7 & 4.8 & 5.7 & 5.7 \\
\hline Transfer payments & 1.5 & 1.4 & 1.6 & 1.7 & 1.7 \\
\hline Of which: Imputed pensions & 1.2 & 1.2 & 1.4 & 1.5 & 1.5 \\
\hline Property income/tax & 1.5 & 1.1 & 1.1 & 1.3 & 1.2 \\
\hline Capital receipts & 3.8 & 4.5 & 4.4 & 3.9 & 4.1 \\
\hline Transfer payments & 2.4 & 3.1 & 3.1 & 2.6 & 2.8 \\
\hline Depreciation & 1.4 & 1.4 & 1.3 & 1.3 & 1.2 \\
\hline Total foreign receipts & 7.8 & 7.0 & 5.4 & 4.9 & 4.9 \\
\hline Current receipts & 7.5 & 6.7 & 5.2 & 4.6 & 4.7 \\
\hline Interest & 1.0 & 0.6 & 0.3 & 0.7 & 0.6 \\
\hline Transfer payments & 6.6 & 6.1 & 4.8 & 3.9 & 4.1 \\
\hline Intergovernmental & 5.6 & 5.2 & 4.1 & 3.1 & 3.5 \\
\hline National and nonprofit institutions & 0.9 & 0.9 & 0.8 & 0.8 & 0.7 \\
\hline Capital receipts & 0.3 & 0.3 & 0.2 & 0.2 & 0.2 \\
\hline Total receipts & 53.1 & 52.8 & 51.8 & 51.8 & 50.8 \\
\hline
\end{tabular}

Source: Bank of Israel, Annual Report 1996.

1/ Figures from 1995 onward include revenue from the health tax. 
Table A34. Israel: General Government Expenditure (National Accounts), 1992-96

\begin{tabular}{|c|c|c|c|c|c|}
\hline & 1992 & 1993 & 1994 & 1995 & 1996 \\
\hline & \multicolumn{5}{|c|}{ (In percent of GDP) } \\
\hline Total domestic expenditure & 52.6 & 51.0 & 49.7 & 51.3 & 51.0 \\
\hline Current expenditure & 45.3 & 44.0 & 43.7 & 45.9 & 45.8 \\
\hline Civilian $1 /$ & 16.6 & 16.7 & 17.1 & 19.1 & 19.8 \\
\hline Defense & 9.0 & 8.1 & 8.1 & 8.1 & 7.6 \\
\hline Transfer payments & 11.0 & 11.1 & 11.1 & 11.6 & 12.3 \\
\hline Subsidies & 3.1 & 2.6 & 2.3 & 1.9 & 1.5 \\
\hline Credit & 0.3 & 0.3 & 0.2 & 0.1 & 0.1 \\
\hline Other & 2.7 & 2.3 & 2.1 & 1.8 & 1.4 \\
\hline Interest & 5.7 & 5.5 & 5.1 & 5.3 & 4.6 \\
\hline Capital expenditure & 7.3 & 6.9 & 5.9 & 5.4 & 5.3 \\
\hline Investment & 3.5 & 3.9 & 3.8 & 3.6 & 3.5 \\
\hline Capital grants & 3.7 & 2.6 & 1.9 & 1.7 & 1.7 \\
\hline Repayment of compulsory loans & 0.1 & 0.4 & 0.2 & 0.1 & 0.1 \\
\hline Total foreign (current) expenditure & 4.5 & 5.4 & 4.4 & 3.9 & 3.9 \\
\hline Defense imports & 1.9 & 2.7 & 1.9 & 1.3 & 1.8 \\
\hline Interest & 2.1 & 2.1 & 2.1 & 2.0 & 1.8 \\
\hline Other & 0.5 & 0.6 & 0.4 & 0.6 & 0.2 \\
\hline Total expenditure & 57.1 & 56.3 & 54.1 & 55.2 & 54.9 \\
\hline
\end{tabular}

Source: Bank of Israel, Annual Report 1996.

1/ Figures from 1995 onward include expenditure arising from the Health Law. 


\begin{tabular}{|c|c|c|c|c|c|}
\hline & 1992 & 1993 & 1994 & 1995 & 1996 \\
\hline & \multicolumn{5}{|c|}{ (In percent of GDP) } \\
\hline Receipts from the public & 53.5 & 53.5 & 52.4 & 52.3 & 50.9 \\
\hline Central government & 43.0 & 42.8 & 42.0 & 41.1 & 39.6 \\
\hline National Insurance Institute & 4.6 & 4.7 & 4.8 & 5.8 & 5.8 \\
\hline National institutions & 0.9 & 1.0 & 0.7 & 0.6 & 0.7 \\
\hline Local authorities & 3.8 & 3.8 & 3.7 & 3.7 & 3.6 \\
\hline Public nonprofit associations & 1.1 & 1.2 & 1.2 & 1.2 & 1.2 \\
\hline Expenditure on the public & 56.8 & 56.2 & 53.7 & 55.5 & 55.0 \\
\hline Central government & 36.4 & 34.8 & 32.6 & 31.7 & 31.1 \\
\hline National Insurance Institute & 7.0 & 7.5 & 7.3 & 7.6 & 7.8 \\
\hline National institutions & 1.0 & 0.9 & 0.9 & 0.8 & 0.8 \\
\hline Local authorities & 6.6 & 7.1 & 7.0 & 7.3 & 7.0 \\
\hline Public nonprofit associations & 5.7 & 6.0 & 5.8 & 8.1 & 8.3 \\
\hline Unilateral transfers to general government entities & 0.0 & 0.0 & 0.0 & 0.0 & 0.0 \\
\hline Central government & 10.3 & 10.5 & 11.3 & 12.2 & 12.7 \\
\hline National Insurance Institute & -3.5 & -3.5 & -3.4 & -2.7 & -2.6 \\
\hline National institutions & 0.0 & 0.0 & 0.0 & 0.0 & 0.0 \\
\hline Local authorities & -2.0 & -2.0 & -2.4 & -2.3 & -2.3 \\
\hline Public nonprofit associations & -4.8 & -5.0 & -5.5 & -7.2 & -7.7 \\
\hline Overall balance & -3.2 & -2.8 & -1.3 & -3.2 & -4.0 \\
\hline Central government & -3.7 & -2.5 & -1.9 & -2.7 & -4.1 \\
\hline National Insurance Institute & 1.1 & 0.8 & 0.9 & 0.8 & 0.6 \\
\hline National institutions & 0.0 & 0.1 & -0.2 & -0.2 & -0.1 \\
\hline Local authorities & -0.9 & -1.3 & -1.0 & -1.3 & -1.1 \\
\hline Public nonprofit associations & 0.2 & 0.2 & 0.8 & 0.3 & 0.7 \\
\hline
\end{tabular}

Source: Bank of Israel, Annual Report 1996. 
Table A36. Israel: The Largest Government Companies

(as of December 31, 1996)

\begin{tabular}{|c|c|c|c|}
\hline & $\begin{array}{c}\text { Total } \\
\text { assets } 1 /\end{array}$ & $\begin{array}{c}\text { Total } \\
\text { revenues 2/ }\end{array}$ & $\begin{array}{l}\text { Percentage direct } \\
\text { and indirect } \\
\text { government } \\
\text { ownership 3/ }\end{array}$ \\
\hline & \multicolumn{3}{|c|}{ (In millions of U.S. dollars) } \\
\hline The Israel Electric Corporation & 10,390 & 2,210 & 100 \\
\hline Bezeq - Telecommunication Corporation & 4,869 & 2,600 & 76 \\
\hline Israel Chemicals & 3,056 & 1,669 & 49 \\
\hline Mekorot - Water Corporation & 2,018 & 455 & 100 \\
\hline Israel Aircraft Industries & 1,635 & 1,496 & 100 \\
\hline Oil Refineries & 1,422 & 2,104 & 74 \\
\hline Israel Military Industries & 672 & 519 & 100 \\
\hline El-Al Israel Airlines & 305 & 380 & 100 \\
\hline
\end{tabular}

Source: Government Companies Authority.

1/ Converted to U.S. dollars using the exchange rate for December 31, 1996.

2/ Converted to U.S. dollars using the average exchange rate for 19.96.

3/ As of December 31, 1996. Subsequently, the government sold additional shares in Bezeq and Israel Chemicals (see next table). 
Table A37. Israel: Privatization and Raising of Capital from the Public by Issuance of Shares and Convertible Securities

(1995 to September 15, 1997)

\begin{tabular}{|c|c|c|c|}
\hline & $\begin{array}{l}\text { Total } \\
\text { capital } \\
\text { raised }\end{array}$ & $\begin{array}{l}\text { Percentage } \\
\text { sold }\end{array}$ & $\begin{array}{c}\text { Percentage held } \\
\text { by the State } \\
\text { after sale }\end{array}$ \\
\hline & $\begin{array}{c}\text { (In millions of } \\
\text { U.S. dollars) }\end{array}$ & & \\
\hline \multicolumn{4}{|l|}{ 1995: } \\
\hline Housing and Development & 288.0 & 100.0 & 0.0 \\
\hline Israel Chemicals & 231.0 & 25.0 & 48.0 \\
\hline Israel Shipyards & 14.0 & 100.0 & 0.0 \\
\hline Total & 533.0 & & \\
\hline \multicolumn{4}{|l|}{ 1996: } \\
\hline Lapidoth Oil Prospectors & 8.6 & 51.0 & 0.0 \\
\hline Tahal Engineers and Consultants & 12.9 & 100.0 & 0.0 \\
\hline Israel Discount Bank & 160.0 & 15.8 & 70.9 \\
\hline Naptha Petrochemical Corporation & 16.4 & 44.0 & 0.0 \\
\hline Total & 197.9 & & \\
\hline \multicolumn{4}{|l|}{ 1997: } \\
\hline Israel Chemicals & 198.0 & 17.0 & 31.5 \\
\hline Yozma Risk Capital & 14.8 & 100.0 & 0.0 \\
\hline Bezeq (Telecommunications) & 48.0 & 2.4 & 73.6 \\
\hline The Israel School of Tourism & 0.3 & 77.9 & 0.0 \\
\hline The Israel National Oil Company & 26.0 & 99.9 & 0.0 \\
\hline Israel Discount Bank & 182.6 & 19.4 & 51.5 \\
\hline Bank Leumi & 407.8 & 18.4 & 63.5 \\
\hline United Mizrahi Bank & 128.7 & 25.0 & 46.0 \\
\hline Bank Hapoalim 2/ & $1,368.0$ & 43.0 & 33.8 \\
\hline Total & $2,374.2$ & & \\
\hline
\end{tabular}

Source: Government Companies Authority.

1/ The conversion to U.S. dollars was done using the exchange rate for the date of sale.

$2 /$ The "percentage sold" figure refers to the percentage sold prior to the exercise of the associated option. After the option is exercised, the State will hold 12.3 percent of the bank. 
Table A38. Israel: Privatization of Banks and Raising of Capital from the Public by Issuance of Shares and Convertible Securities, 1991-97

\begin{tabular}{|c|c|c|c|c|}
\hline Bank & Date & $\begin{array}{c}\text { Total } \\
\text { capital } \\
\text { raised } 1 /\end{array}$ & $\begin{array}{l}\text { Percentage } \\
\text { sold }\end{array}$ & $\begin{array}{l}\text { Percentage held } \\
\text { by the State } \\
\text { after sale }\end{array}$ \\
\hline & & $\begin{array}{l}\text { (In millions of } \\
\text { U.S. dollars) }\end{array}$ & & \\
\hline I.D.B. Holdings & October 1991 & 229.7 & 25.0 & 42.0 \\
\hline Israel General Bank & July 1992 & 15.6 & 25.0 & 0.0 \\
\hline I.D.B. Holdings & November 1992 & 349.3 & 42.0 & 0.0 \\
\hline Union Bank & May 1993 & 49.6 & 35.0 & 23.0 \\
\hline Bank Hapoalim & May 1993 & 244.5 & 16.0 & 80.0 \\
\hline Bank Leumi & August 1993 & 275.4 & 15.0 & 80.0 \\
\hline Bank Hapoalim & November 1993 & 121.8 & 6.0 & 74.0 \\
\hline United Mizrahi Bank 2/ & November 1994 & 110.0 & 51.0 & 46.0 \\
\hline Israel Discount Bank 3/ & March 1996 & 160.0 & 15.8 & 70.9 \\
\hline Israel Discount Bank & April 1997 & 182.6 & 19.4 & 51.5 \\
\hline Bank Leumi & May 1997 & 407.8 & 18.4 & 63.5 \\
\hline United Mizrahi Bank & July 1997 & 128.7 & 25.0 & 46.0 \\
\hline Bank Hapoalim 4/ & September 1997 & $1,368.0$ & 43.0 & 33.8 \\
\hline
\end{tabular}

Source: Government Companies Authority.

1/ The conversion to U.S. dollars was done using the exchange rate for the date of sale.

2/ The purchasers of the controlling interest of United Mizrahi Bank (26 percent of its capital) were granted an option to purchase a further 25 percent on the basis of the market value (100 percent) of the bank, amounting to $\$ 23$ million, plus linkage to the $\mathrm{CPI}$ and interest at the rate of 3 percent. The proceeds due to arise upon the exercise of warrant are not included here.

3 / The immediate revenue amounts to $\$ 80$ million. Another $\$ 80$ million in revenue is expected upon the exercise of the purchase warrants in Israel Discount Bank.

4/ The "percentage sold" figure refers to the percentage sold prior to the exercise of the associated option. After the option is exercised, the State will hold 12.3 percent of the bank. 
Table A39. Israel: Currency Basket of the Israeli Sheqel, 1992-97

\begin{tabular}{|c|c|c|c|c|c|c|c|}
\hline & \multirow{2}{*}{$\begin{array}{l}\text { Absolute amount } \\
\text { of currency in } \\
\text { basket as of } \\
\text { Dec. } 31,1996\end{array}$} & \multicolumn{6}{|c|}{$\begin{array}{l}\text { Percentage distribution of currencies on the } \\
\text { basis of market rates on: }\end{array}$} \\
\hline & & $\begin{array}{c}1992 \\
\text { Dec. } 31\end{array}$ & $\begin{array}{c}1993 \\
\text { Dec. } 31\end{array}$ & $\begin{array}{c}1994 \\
\text { Dec. } 31\end{array}$ & $\begin{array}{c}1995 \\
\text { Dec. } 31\end{array}$ & $\begin{array}{c}1996 \\
\text { Dec. } 31\end{array}$ & $\begin{array}{c}1997 \\
\text { Sept. } 30\end{array}$ \\
\hline U.S. dollar & 0.6741 & 0.5537 & 0.5627 & 0.5381 & 0.5583 & 0.6028 & 0.6269 \\
\hline Deutschemark & 0.3588 & 0.2387 & 0.2258 & 0.2419 & 0.2424 & 0.2070 & 0.1877 \\
\hline Pound sterling & 0.0589 & 0.0938 & 0.0929 & 0.0939 & 0.0819 & 0.0895 & 0.0896 \\
\hline Japanese yen & 6.5437 & 0.0570 & 0.0646 & 0.0692 & 0.0597 & 0.0505 & 0.0501 \\
\hline French franc & 0.2933 & 0.0569 & 0.0540 & 0.0569 & 0.0577 & 0.0502 & 0.0458 \\
\hline
\end{tabular}

Sources: IMF, International Financial Statistics; and data provided by the Bank of Israel. 
Table A40. Israel: Exchange Rate Developments, 1992-97

\begin{tabular}{|c|c|c|c|c|c|c|}
\hline & $\begin{array}{l}\text { U.S.dollar/ } \\
\text { sheqel }\end{array}$ & $\begin{array}{c}\text { Deutsche } \\
\text { mark/ } \\
\text { sheqel }\end{array}$ & $\begin{array}{l}\text { Pound } \\
\text { sterling/ } \\
\text { sheqel }\end{array}$ & $\begin{array}{c}\text { Japanese } \\
\text { yen/ } \\
\text { sheqel }\end{array}$ & $\begin{array}{l}\text { French } \\
\text { franc/ } \\
\text { sheqel }\end{array}$ & $\begin{array}{c}\text { Currency } \\
\text { basket }\end{array}$ \\
\hline & \multicolumn{6}{|c|}{ (Index number $1986=100 ;$ period averages) } \\
\hline 1992 & 165.3 & 229.0 & 198.9 & 218.2 & 216.3 & 186.3 \\
\hline 1993 & 190.4 & 248.2 & 194.8 & 286.9 & 232.0 & 208.8 \\
\hline 1994 & 202.4 & 269.8 & 211.5 & 331.1 & 252.5 & 225.3 \\
\hline 1995 & 202.4 & 304.7 & 217.8 & 361.2 & 280.2 & 235.7 \\
\hline 1996 & 214.3 & 307.3 & 228.4 & 329.0 & 289.3 & 243.9 \\
\hline \multicolumn{7}{|l|}{1992} \\
\hline $\mathrm{I}$ & 157.4 & 210.1 & 190.4 & 204.8 & 197.6 & 175.4 \\
\hline $\mathrm{II}$ & 163.5 & 218.6 & 201.5 & 209.7 & 207.7 & 182.6 \\
\hline III & 164.3 & 242.1 & 214.0 & 219.4 & 228.7 & 190.5 \\
\hline IV & 176.3 & 244.6 & 189.0 & 239.0 & 230.6 & 196.8 \\
\hline \multicolumn{7}{|l|}{1993} \\
\hline I & 187.6 & 247.6 & 189.0 & 259.5 & 233.7 & 205.3 \\
\hline II & 184.8 & 246.2 & 193.3 & 281.0 & 233.8 & 204.8 \\
\hline III & 191.2 & 245.6 & 196.1 & 302.4 & 226.7 & 209.5 \\
\hline IV & 197.4 & 252.9 & 200.8 & 304.3 & 233.6 & 215.6 \\
\hline \multicolumn{7}{|l|}{1994} \\
\hline I & 200.1 & 250.6 & 203.1 & 310.7 & 235.9 & 217.5 \\
\hline II & 203.0 & 264.1 & 208.4 & 328.3 & 247.1 & 223.8 \\
\hline III & 203.6 & 281.0 & 215.1 & 342.9 & 262.7 & 229.6 \\
\hline IV & 203.0 & 283.7 & 219.4 & 342.8 & 264.6 & 230.2 \\
\hline \multicolumn{7}{|l|}{1995} \\
\hline I & 201.6 & 294.2 & 217.6 & 350.4 & 269.7 & 231.9 \\
\hline II & 200.5 & 309.3 & 218.3 & 395.9 & 281.4 & 236.9 \\
\hline III & 202.1 & 304.5 & 216.9 & 360.4 & 282.1 & 235.5 \\
\hline IV & 205.5 & 311.5 & 218.6 & 338.0 & 288.0 & 238.4 \\
\hline \multicolumn{7}{|l|}{1996} \\
\hline I & 209.3 & 307.7 & 218.7 & 330.5 & 287.3 & 239.9 \\
\hline II & 217.0 & 307.2 & 225.5 & 337.4 & 290.3 & 245.8 \\
\hline III & 212.6 & 306.4 & 225.4 & 325.9 & 288.3 & 242.1 \\
\hline IV & 218.2 & 307.8 & 243.3 & 323.2 & 291.4 & 247.8 \\
\hline \multicolumn{7}{|l|}{1997} \\
\hline I & 223.2 & 291.5 & 248.7 & 308.5 & 276.5 & 247.7 \\
\hline II & 229.5 & 288.8 & 256.0 & 320.9 & 274.2 & 252.5 \\
\hline III & 237.1 & 283.3 & 263.1 & 335.8 & 269.3 & 257.8 \\
\hline
\end{tabular}

Sources: IMF, International Financial Statistics; and data provided by the Bank of Israel. 
Table A41. Israel: Overall Balance of Payments, 1992-97

\begin{tabular}{|c|c|c|c|c|c|c|}
\hline & 1992 & 1993 & 1994 & 1995 & 1996 & 1997 \\
\hline & & & & & & Jan.-June \\
\hline & \multicolumn{6}{|c|}{ (In millions of U.S. dollars) } \\
\hline Current account balance & -236 & $-1,774$ & $-2,511$ & $-4,843$ & $-5,348$ & $-2,329$ \\
\hline Trade balance & $-4,846$ & $-5,756$ & $-5,533$ & $-7,532$ & $-7,595$ & $-3,018$ \\
\hline Exports, f.o.b. & 13,392 & 14,638 & 17,087 & 19,133 & 20,641 & 10,876 \\
\hline Imports, f.o.b. & 18,238 & 20,394 & 22,620 & 26,665 & 28,236 & 13,894 \\
\hline Civilian imports.. & 16,790 & 18,287 & 21,159 & 25,372 & 26,565 & 13,038 \\
\hline Military imports & 1,448 & 2,106 & 1,461 & 1,293 & 1,671 & 856 \\
\hline Civilian trade balance & $-3,398$ & $-3,649$ & $-4,072$ & $-6,239$ & $-5,924$ & $-2,162$ \\
\hline Services balance & $-2,142$ & $-2,707$ & $-3,937$ & $-4,508$ & $-5,516$ & $-2,434$ \\
\hline Exports & 7,442 & 7,361 & 7,829 & 9,577 & 9,883 & 5,276 \\
\hline Imports & 9,584 & 10,068 & 11,766 & 14,085 & 15,399 & 7,710 \\
\hline Net transfers & 6,752 & 6,689 & 6,959 & 7,197 & 7,763 & 3,123 \\
\hline Capital account balance & $-1,299$ & 3,078 & 2,198 & 4,531 & 6,740 & 8,227 \\
\hline Long-term capital & -459 & 2,239 & 3,024 & 2,572 & 4,761 & 2,059 \\
\hline Short-term capital & -840 & 839 & -826 & 1,959 & 1,979 & 6,168 \\
\hline Errors and omissions & -558 & 175 & 382 & 1,544 & 2,088 & 202 \\
\hline \multirow[t]{2}{*}{ Change in reserves } & 1,466 & $-1,480$ & -70 & $-1,232$ & $-3,479$ & $-6,100$ \\
\hline & \multicolumn{6}{|c|}{ (Percentage change from same period previous year) } \\
\hline \multicolumn{7}{|l|}{ Memorandum items: } \\
\hline Goods exports & 11.3 & 9.3 & 16.7 & 12.0 & 7.9 & 10.3 \\
\hline Goods imports & 7.7 & 11.8 & 10.9 & 17.9 & 5.9 & -1.0 \\
\hline Services exports & 15.6 & -1.1 & 6.4 & 22.3 & 3.2 & 7.7 \\
\hline Services imports & 10.6 & 5.1 & 16.9 & 19.7 & 9.3 & 7.3 \\
\hline GDP (in billions of dollars) & 65.4 & 65.3 & 74.1 & 86.7 & 95.2 & 99.4 \\
\hline
\end{tabular}

Source: Central Bureau of Statistics, Monthly Bulletin of Statistics . 
Table A42. Israel: Balance of Payments-Services, 1992-97

\begin{tabular}{|c|c|c|c|c|c|c|}
\hline & 1992 & 1993 & 1994 & 1995 & 1996 & 1997 \\
\hline & \multicolumn{6}{|c|}{ (In millions of U.S. dollars) } \\
\hline Freight and transportation, net & -733 & $-1,107$ & $-1,432$ & $-1,718$ & $-1,915$ & -862 \\
\hline Receipts & 1,683 & 1,765 & 1,795 & 2,146 & 2,045 & 1,071 \\
\hline Payments & 2,416 & 2,872 & 3,227 & 3,864 & 3,960 & 1,933 \\
\hline Travel, net & 221 & 175 & -136 & -210 & -362 & -11 \\
\hline Receipts & 1,895 & 2,227 & 2,459 & 2,938 & 2,942 & 1,391 \\
\hline Payments & 1,674 & 2,052 & 2,595 & 3,148 & 3,304 & 1,402 \\
\hline Insurance, net & -57 & -191 & -198 & -234 & -200 & -104 \\
\hline Receipts & -14 & 13 & 13 & 12 & 13 & 12 \\
\hline Payments & 43 & 204 & 211 & 246 & 213 & 116 \\
\hline Other, net & 12 & -196 & -421 & -777 & $-1,281$ & -652 \\
\hline Receipts & 2,516 & 2,222 & 2,469 & 2,712 & 3,092 & 1,772 \\
\hline Payments & 2,504 & 2,418 & 2,890 & 3,489 & 4,373 & 2,424 \\
\hline Government, n.e.s., net & -110 & -145 & -154 & -154 & -132 & -50 \\
\hline Receipts & 53 & 47 & 50 & 64 & 86 & 49 \\
\hline Payments & 163 & 192 & 204 & 218 & 218 & 99 \\
\hline \multicolumn{7}{|l|}{ Total services (excluding } \\
\hline investment income), net & -667 & $-1,464$ & $-2,341$ & $-3,093$ & $-3,890$ & $-1,679$ \\
\hline Receipts & 6,133 & 6,274 & $6 ; 786$ & 7,872 & 8,178 & 4,295 \\
\hline Payments & 6,800 & 7,738 & 9,127 & 10,965 & 12,068 & 5,974 \\
\hline Investment income, net & $-1,061$ & $-1,241$ & $-1,594$ & $-1,416$ & $-1,626$ & -755 \\
\hline Receipts & 1,473 & 1,088 & 1,043 & 1,705 & 1,705 & 981 \\
\hline Payments & 2,534 & 2,329 & 2,637 & 3,121 & 3,331 & 1,736 \\
\hline Total services, net & $-1,728$ & $-2,705$ & $-3,935$ & $-4,509$ & $-5,516$ & $-2,434$ \\
\hline Receipts & 7,606 & 7,362 & 7,829 & 9,577 & 9,883 & 5,276 \\
\hline Payments & 9,334 & 10,067 & 11,764 & 14,086 & 15,399 & 7,710 \\
\hline
\end{tabular}

Source: Central Bureau of Statistics, Monthly Bulletin of Statistics . 
Table A43. Israel: Export Volume and Price Indices, 1992-97

\begin{tabular}{|c|c|c|c|c|c|c|c|}
\hline & \multirow[t]{2}{*}{1992} & \multirow[t]{2}{*}{1993} & \multirow[t]{2}{*}{1994} & \multirow[t]{2}{*}{1995} & \multirow[t]{2}{*}{1996} & \multicolumn{2}{|c|}{1997} \\
\hline & & & & & & Q1 & Q2 \\
\hline & \multicolumn{7}{|c|}{ (Percentage change from same period previous year) } \\
\hline \multicolumn{8}{|l|}{ Volume indices $1 /$} \\
\hline Agricultural products & -2.5 & 1.9 & 11.2 & 14.6 & 15.7 & 9.6 & -1.9 \\
\hline Citrus fruit & -14.2 & -11.3 & -0.8 & 37.1 & -5.6 & 6.2 & 23.0 \\
\hline Other fruits and vegetables & -8.9 & 8.1 & 0.7 & 21.6 & 32.0 & 49.1 & -61.1 \\
\hline Other & 6.4 & 4.7 & 21.7 & 2.8 & 19.7 & 45.6 & -12.1 \\
\hline Industrial products (excl. diamonds) & 10.7 & 19.2 & 13.8 & 3.5 & 7.0 & 12.8 & 14.0 \\
\hline Ores and minerals & -5.1 & 4.9 & 18.6 & 1.5 & -9.1 & 7.0 & 8.9 \\
\hline Food & -4.4 & 10.4 & 5.5 & 2.8 & -3.7 & -10.5 & -23.1 \\
\hline Textiles & 13.2 & 2.3 & 7.8 & 2.1 & -5.4 & -10.8 & -3.1 \\
\hline Metals, machinery and electronics & 12.8 & 25.8 & 15.7 & 0.6 & 13.4 & -3.6 & 2.9 \\
\hline Chemicals & 8.1 & 27.0 & 14.6 & 6.3 & 4.4 & 20.9 & 25.2 \\
\hline Other industrial products & 17.6 & 4.3 & 10.2 & 14.1 & 4.1 & -10.7 & 1.1 \\
\hline Diamonds, net & 12.1 & -0.2 & 23.3 & 12.2 & 4.0 & 5.3 & -15.5 \\
\hline Total exports & 10.4 & 12.3 & 15.5 & 6.5 & 7.1 & 10.0 & 10.7 \\
\hline Total exports, excluding diamonds & 9.9 & 16.7 & 13.1 & 4.6 & 8.2 & 0.6 & -2.5 \\
\hline \multicolumn{8}{|l|}{ Price indices $2 /$} \\
\hline Agricultural products & -11.8 & -2.9 & -2.5 & 8.8 & -6.6 & -4.3 & -9.9 \\
\hline Citrus fruit & -10.2 & 18.1 & 5.5 & 17.3 & -6.0 & -5.6 & -21.4 \\
\hline Other fruits and vegetables & -11.0 & -3.1 & -4.7 & 8.3 & -12.3 & -5.7 & -4.8 \\
\hline Other & -12.8 & -10.1 & -4.5 & 5.1 & -3.8 & 15.1 & -22.6 \\
\hline Industrial products (excl. diamonds) & 1.6 & -3.3 & -0.6 & 5.5 & -0.9 & -2.2 & -1.7 \\
\hline Ores and minerals & 4.8 & -8.0 & -1.2 & 13.2 & 3.8 & 6.2 & 5.9 \\
\hline Food & 8.5 & -10.4 & -0.7 & 7.2 & 2.5 & -2.1 & -0.2 \\
\hline Textiles & 1.0 & -4.9 & 1.6 & 4.8 & 2.0 & 4.2 & 4.4 \\
\hline Metals, machinery and electronics & 2.0 & -1.4 & 0.8 & 4.9 & -2.1 & -1.9 & -0.7 \\
\hline Chemicals & -1.7 & -5.2 & -3.2 & 5.2 & -2.3 & -3.1 & -1.1 \\
\hline Other industrial products & 2.0 & -0.3 & -1.8 & 5.9 & 1.0 & 1.3 & 2.1 \\
\hline Diamonds, net & 1.1 & 10.3 & -3.0 & 2.7 & 2.5 & 0.0 & 5.8 \\
\hline Total exports & 0.7 & 0.5 & -1.4 & 4.7 & -0.1 & 0.1 & 0.7 \\
\hline Total exports, excluding diamonds & 0.6 & -2.5 & -0.8 & 5.4 & -1.0 & -1.1 & -0.6 \\
\hline
\end{tabular}

Sources: Central Bureau of Statistics, Foreign Trade Statistics Quarterly; and data provided by the Bank of Israel.

1/ Value data deflated by Fisher unit value indices.

2/ Based on data in U.S. dollars. 
Table A44. Israel: Commodity Composition of Exports, 1992-97 1/ 2/

\begin{tabular}{|c|c|c|c|c|c|c|}
\hline & 1992 & 1993 & 1994 & 1995 & 1996 & $\frac{1997}{\operatorname{Jan} .-\operatorname{Jun} e}$ \\
\hline . & \multicolumn{6}{|c|}{ (In millions of U.S. dollars) } \\
\hline Agricultural products & 554 & 548 & 594 & 741 & 801 & 564 \\
\hline Citrus fruits & 115 & 121 & 126 & 203 & 180 & 124 \\
\hline Other fruits and vegetables & 137 & 143 & 137 & 181 & 209 & 117 \\
\hline Other & 302 & 284 & 330 & 357 & 411 & 258 \\
\hline Industrial products (excluding diamonds) & 8,637 & 9,959 & 11,281 & 12,224 & 12,986 & 9,312 \\
\hline Ores and minerals & 294 & 283 & 332 & 382 & 360 & 204 \\
\hline Food, beverages, and tobacco & 540 & 534 & 559 & 617 & 608 & 268 \\
\hline Textiles, clothing and leather & 908 & 883 & 968 & 1,036 & 999 & 474 \\
\hline Other light industry products & 1,151 & 1,199 & 1,301 & 1,574 & 1,657 & 836 \\
\hline Chemicals & 1,589 & 1,912 & 2,120 & 2,370 & 2,419 & 1,409 \\
\hline Metals, machinery and electronics & 4,080 & 5,058 & 5,894 & 6,222 & 6,902 & 3,709 \\
\hline Diamonds & 3,049 & 3,356 & 4,015 & 4,623 & 4,929 & 3,534 \\
\hline Other exports, n.e.s. $3 /$ & 239 & 220 & 162 & 216 & 355 & 226 \\
\hline \multirow[t]{2}{*}{ Total exports } & 12,479 & 14,083 & 16,051 & 17,802 & 19,069 & 13,635 \\
\hline & \multicolumn{6}{|c|}{ (In percent of total exports) } \\
\hline Agricultural products & 4.4 & 3.9 & 3.7 & 4.2 & 4.2 & 4.1 \\
\hline Citrus fruits & 0.9 & 0.9 & 0.8 & 1.1 & 0.9 & 0.9 \\
\hline Other fruits and vegetables & 1.1 & 1.0 & 0.9 & 1.0 & 1.1 & 0.9 \\
\hline Other & 2.4 & 2.0 & 2.1 & 2.0 & 2.2 & 1.9 \\
\hline Industrial products (excluding diamonds) & 69.2 & 70.7 & 70.3 & 68.7 & 68.1 & 68.3 \\
\hline Ores and minerals & 2.4 & 2.0 & 2.1 & 2.1 & 1.9 & 1.5 \\
\hline Food, beverages, and tobacco & 4.3 & 3.8 & 3.5 & 3.5 & 3.2 & 2.0 \\
\hline Textiles, clothing and leather & 7.3 & 6.3 & 6.0 & 5.8 & 5.2 & 3.5 \\
\hline Other light industry products & 9.2 & 8.5 & 8.1 & 8.8 & 8.7 & 6.1 \\
\hline Chemicals & 12.7 & 13.6 & 13.2 & 13.3 & 12.7 & 10.3 \\
\hline Metals, machinery and electronics & 32.7 & 35.9 & 36.7 & 35.0 & 36.2 & 27.2 \\
\hline Diamonds & 24.4 & 23.8 & 25.0 & 26.0 & 25.8 & 25.9 \\
\hline Other exports, n.e.s. $3 /$ & 1.9 & 1.6 & 1.0 & 1.2 & 1.9 & 1.7 \\
\hline Total exports & 100.0 & 100.0 & 100.0 & 100.0 & 100.0 & 100.0 \\
\hline
\end{tabular}

Sources: Central Bureau of Statistics, Foreign Trade Statistics Quarterly and Monthly Bulletin of Statistics.

$1 /$ Excluding exports to the Autonomy and administered areas.

2/ The valuation basis in this table differs from that used in the balance of payments.

3/ Returned exports and items not specified elsewhere. 
Table A45. Israel: Destination of Exports, 1992-97.

\begin{tabular}{|c|c|c|c|c|c|c|}
\hline & 1992 & 1993 & 1994 & 1995 & 1996 & $19971 /$ \\
\hline & \multicolumn{6}{|c|}{ (In percent of total exports) } \\
\hline Exports & 100.0 & 100.0 & 100.0 & 100.0 & 100.0 & 100.0 \\
\hline Europe & 40.0 & 37.2 & 35.6 & 39.2 & 38.8 & 37.2 \\
\hline \multicolumn{7}{|l|}{$\begin{array}{l}\text { Europe } \\
\text { Of which: }\end{array}$} \\
\hline European Union & 35.6 & 30.6 & 29.9 & 32.3 & 32.1 & 30.1 \\
\hline Austria & 0.5 & 0.5 & 0.5 & 0.4 & 0.4 & 0.3 \\
\hline Belgium & 4.9 & 5.3 & 5.2 & 5.3 & 5.4 & 4.9 \\
\hline Denmark & 0.3 & 0.3 & 0.2 & 0.3 & 0.3 & 0.2 \\
\hline Finland & 0.1 & 0.1 & 0.1 & 0.2 & 0.3 & 0.2 \\
\hline France & 4.7 & 3.9 & 3.5 & 3.7 & 3.3 & 2.8 \\
\hline Germany & 5.9 & 5.3 & 5.0 & 5.5 & 5.1 & 4.4 \\
\hline Greece & 0.8 & 0.8 & 0.6 & 1.1 & 0.8 & 0.7 \\
\hline Ireland & 0.2 & 0.2 & 0.2 & 0.2 & 0.4 & 0.7 \\
\hline Italy & 3.5 & 2.9 & 3.0 & 3.0 & 2.7 & 2.8 \\
\hline Luxembourg & 0.1 & 0.0 & 0.0 & 0.0 & 0.0 & 0.0 \\
\hline Netherlands & 4.2 & 3.7 & 4.0 & 4.2 & 4.3 & 4.3 \\
\hline Portugal & 0.3 & 0.3 & 0.2 & 0.2 & 0.2 & 0.2 \\
\hline Spain & 1.8 & 1.3 & 1.5 & 1.6 & 1.7 & 1.6 \\
\hline Sweden & 0.4 & 0.4 & 0.5 & 0.5 & 0.6 & 0.4 \\
\hline United Kingdom & 7.7 & 5.5 & 5.3 & 6.1 & 6.7 & 6.4 \\
\hline EFTA countries $2 /$ & 2.0 & 2.0 & 2.1 & 2.0 & 1.7 & 1.8 \\
\hline North, Central, and South America & 33.6 & 34.5 & 35.8 & 33.7 & 34.3 & 35.2 \\
\hline \multicolumn{7}{|l|}{$\begin{array}{l}\text { North, Central, and south funterica } \\
\text { Of which: }\end{array}$} \\
\hline United States & 30.5 & 31.2 & 32.0 & 30.1 & 30.6 & 31.3 \\
\hline Asia & 15.6 & 16.9 & 19.5 & 20.1 & 20.1 & 19.8 \\
\hline \multicolumn{7}{|l|}{$\begin{array}{l}\text { Asia } \\
\text { Of which: }\end{array}$} \\
\hline Japan & 5.2 & 5.2 & 5.9 & 6.9 & 5.9 & 4.8 \\
\hline Other countries & 10.8 & 11.3 & 9.2 & 7.1 & 6.8 & 7.7 \\
\hline
\end{tabular}

Source: Central Bureau of Statistics, Monthly Bulletin of Statistics.

1/ Based on January-August data.

2) Iceland, Norway, and Switzerland. 
Table A46. Israel: Civilian Import Volume and Price Indices, 1992-97

\begin{tabular}{|c|c|c|c|c|c|c|c|}
\hline & \multirow[t]{2}{*}{1992} & \multirow[t]{2}{*}{1993} & \multirow[t]{2}{*}{1994} & \multirow[t]{2}{*}{1995} & \multirow[t]{2}{*}{1996} & \multicolumn{2}{|c|}{1997} \\
\hline & & & & & & Q1 & Q2 \\
\hline & \multicolumn{7}{|c|}{ (Percentage change from same period previous year) } \\
\hline \multicolumn{8}{|l|}{ Volume indices 1/ } \\
\hline Consumer goods & 20.5 & 8.9 & 19.4 & 11.2 & 12.0 & -2.2 & 8.3 \\
\hline Nondurables & 15.2 & 20.6 & 24.4 & 9.5 & 14.1 & 12.4 & -7.1 \\
\hline Durables & 25.5 & -0.8 & 14.6 & 12.9 & 9.8 & -3.1 & 7.4 \\
\hline Input goods & 11.8 & 13.2 & 9.7 & 11.7 & 4.4 & 1.2 & 6.7 \\
\hline Diamonds & 5.9 & 13.5 & 11.1 & 19.9 & 2.3 & 5.8 & 13.9 \\
\hline Fuel & 22.2 & 14.6 & -2.2 & 9.3 & -6.7 & 18.7 & 40.8 \\
\hline Other & 14.7 & 15.3 & 11.4 & 9.1 & 5.4 & 7.2 & -0.8 \\
\hline Investment goods & 3.8 & 13.9 & 23.8 & 3.2 & 10.3 & -5.3 & -13.7 \\
\hline Machinery and equipment & 3.9 & 16.8 & 17.1 & 11.4 & 11.2 & -7.3 & -13.0 \\
\hline Total imports, net & 11.3 & 12.7 & 13.2 & 10.4 & 6.3 & 0.0 & 3.0 \\
\hline Total imports, excluding diamonds & 12.3 & 12.6 & 13.6 & 8.6 & 7.1 & 4.5 & -2.2 \\
\hline \multicolumn{8}{|l|}{ Price indices $2 /$} \\
\hline Consumer goods & 2.6 & 0.2 & 0.8 & 8.0 & -3.7 & -5.2 & -4.1 \\
\hline Nondurables & 1.1 & -3.2 & -0.3 & 8.8 & -2.6 & -2.5 & 1.1 \\
\hline Durables & 4.0 & 3.5 & 1.9 & 7.1 & -4.9 & -6.3 & -7.1 \\
\hline Input goods & -1.1 & -4.4 & 2.5 & 9.1 & 0.7 & -2.8 & -4.1 \\
\hline Diamonds & 7.7 & 1.1 & 4.3 & -4.6 & 6.3 & 2.5 & 5.0 \\
\hline Fuel & -4.9 & -11.3 & -2.6 & 10.3 & 14.9 & 9.1 & -11.3 \\
\hline Other & -5.5 & -7.0 & 2.7 & 14.4 & -1.7 & -2.3 & -4.2 \\
\hline Investment goods $3 /$ & 2.2 & -1.3 & 0.3 & 5.1 & -2.0 & -4.2 & -5.2 \\
\hline Machinery and equipment & 2.2 & -3.6 & 0.3 & 5.1 & -2.0 & -4.4 & -5.3 \\
\hline Total imports, net & -0.1 & -3.3 & 2.1 & 8.5 & -0.6 & -3.4 & -4.3 \\
\hline Total imports, excluding diamonds 3 / & -1.5 & -4.1 & 1.7 & 11.2 & -1.8 & -2.8 & -1.9 \\
\hline
\end{tabular}

Sources: Central Bureau of Statistics, Foreign Trade Statistics Quarterly; and data provided by the Bank of Israel.

1/ Value data deflated by Fisher unit value indices.

2/ Based on data in U.S. dollars.

3/Excluding ships and aircraft. 
Table A47. Israel: Commodity Composition of Civilian Imports (c.i.f), 1992-97 1/

\begin{tabular}{|c|c|c|c|c|c|c|}
\hline & 1992 & 1993 & 1994 & 1995 & 1996 & 1997 \\
\hline & & & & & & Jan.-June \\
\hline & \multicolumn{6}{|c|}{ (In millions of U.S. dollars) } \\
\hline & & & , & & & \\
\hline Consumer goods & 2,320 & 2,533 & 3,047 & 3,657 & 3,942 & 2,566 \\
\hline Nondurables & 1,070 & 1,248 & 1,846 & 1,846 & 2,051 & 1,039 \\
\hline Durables & 1,250 & 1,283 & 1,811 & 1,811 & 1,890 & 919 \\
\hline Input goods & 13,270 & 14,391 & 15,890 & 19,371 & 20,323 & 13,312 \\
\hline Diamonds & 2,911 & 3,542 & 3,873 & 4,430 & 4,819 & 3,205 \\
\hline Fuel & 1,713 & 1,742 & 1,658 & 1,999 & 2,141 & 1,514 \\
\hline Other & 8,646 & 9,107 & 10,358 & 12,942 & 13,363 & 8,593 \\
\hline Investment goods & 3,180 & 3,577 & 4,510 & 4,951 & 5,315 & 3,254 \\
\hline Machinery and equipment & 2,240 & 2,522 & 3,468 & 3,468 & 3,780 & 1,700 \\
\hline Other imports, n.e.s. $2 /$ & -232 & 18 & -77 & -74 & -102 & -67 \\
\hline Total imports, net & 18,538 & 20,518 & 23,369 & 27,905 & 29,478 & 19,065 \\
\hline \multirow[t]{2}{*}{ Total imports, excluding diamonds } & 15,627 & 16,976 & 19,496 & 23,475 & 24,660 & 15,860 \\
\hline & \multicolumn{6}{|c|}{ (In percent of total imports) } \\
\hline Consumer goods & 12.5 & 12.3 & 13.0 & 13.1 & 13.4 & 13.5 \\
\hline Nondurables & 5.8 & 6.1 & 7.9 & 6.6 & 7.0 & 5.4 \\
\hline Durables & 6.7 & 6.3 & 7.7 & 6.5 & 6.4 & 4.8 \\
\hline Input goods & 71.6 & 70.1 & 68.0 & 69.4 & 68.9 & 69.8 \\
\hline Diamonds & 15.7 & 17.3 & 16.6 & 15.9 & 16.3 & 16.8 \\
\hline Fuel & 15.7 & 17.3 & 16.6 & 15.9 & 16.3 & 16.8 \\
\hline Other & 46.6 & 44.4 & 44.3 & 46.4 & 45.3 & 45.1 \\
\hline Investment goods & 17.2 & 17.4 & 19.3 & 17.7 & 18.0 & 17.1 \\
\hline Machinery and equipment & 12.1 & 12.3 & 14.8 & 12.4 & 12.8 & 8.9 \\
\hline Other imports, n.e.s. $2 /$ & -1.3 & 0.1 & -0.3 & -0.3 & -0.3 & -0.4 \\
\hline Total imports, net & 100.0 & 100.0 & 100.0 & 100.0 & 100.0 & 100.0 \\
\hline
\end{tabular}

Sources: Central Bureau of Statistics, Foreign Trade Statistics Quarterly and Monthly Bulletin of Statistics.

1/ Excludes imports from the Autonomy and administered areas.

$2 /$ Returned and re-exported imports, and items not specified elsewhere. 
Table A48. Israel: Origin of Imports, 1992-97

\begin{tabular}{|c|c|c|c|c|c|c|}
\hline & 1992 & 1993 & 1994 & 1995 & 1996 & $19971 /$ \\
\hline & \multicolumn{6}{|c|}{ (In percent of total imports) } \\
\hline Imports & 100.0 & 100.0 & 100.0 & 100.0 & 100.0 & 100.0 \\
\hline Europe & 61.2 & 61.0 & 61.7 & 61.7 & 60.2 & 59.5 \\
\hline \multicolumn{7}{|l|}{ Of which: } \\
\hline European Union & 52.3 & 51.4 & 52.6 & 52.4 & 51.7 & 50.7 \\
\hline Austria & 0.5 & 0.6 & 0.5 & 0.6 & 0.5 & 0.5 \\
\hline Belgium & 12.7 & 12.1 & 12.0 & 12.1 & 12.1 & 12.1 \\
\hline Denmark & 0.7 & 0.7 & 0.6 & 0.6 & 0.5 & 0.5 \\
\hline Finland & 0.5 & 0.5 & 0.5 & 0.8 & 0.7 & 0.9 \\
\hline France & 4.5 & 4.2 & 4.5 & 4.1 & 3.9 & 3.7 \\
\hline Germany & 11.9 & 10.4 & 10.3 & 9.8 & 9.4 & 9.4 \\
\hline Greece & 0.4 & 0.4 & 0.5 & 0.5 & 0.5 & 0.4 \\
\hline Ireland & 0.3 & 0.3 & 0.4 & 0.6 & 0.6 & 0.6 \\
\hline Italy & 7.0 & 7.3 & 7.7 & 7.8 & 7.6 & 6.9 \\
\hline Luxembourg & 0.1 & 0.1 & 0.1 & 0.1 & 0.1 & 0.1 \\
\hline Netherlands & 3.3 & 3.4 & 3.3 & 3.4 & 3.2 & 3.4 \\
\hline Portugal & 0.3 & 0.4 & 0.5 & 0.4 & 0.4 & 0.4 \\
\hline Spain & 1.1 & 1.0 & 1.6 & 1.9 & 2.1 & 2.0 \\
\hline Sweden & 1.1 & 1.4 & 1.4 & 1.4 & 1.2 & 1.0 \\
\hline United Kingdom & 8.0 & 8.6 & 8.5 & 8.3 & 8.8 & 8.8 \\
\hline EFTA countries $2 /$ & 7.5 & 7.7 & 6.7 & 6.3 & 5.8 & 5.9 \\
\hline $\begin{array}{l}\text { North, Central, and South America } \\
\text { Of which: }\end{array}$ & 19.0 & \multicolumn{4}{|c|}{ Of which: } & 21.1 \\
\hline United States & 17.2 & 17.8 & 18.5 & 18.6 & 20.0 & 19.1 \\
\hline Asia & 9.4 & 10.0 & 9.6 & 10.0 & 10.2 & 10.8 \\
\hline \multicolumn{7}{|l|}{ Of which: } \\
\hline Japan & 5.3 & 5.1 & 4.0 & 3.3 & 3.7 & 3.7 \\
\hline Other countries & 10.4 & 9.7 & 8.3 & 8.1 & 8.1 & 8.6 \\
\hline
\end{tabular}

Source: Central Bureau of Statistics, Monthly Bulletin of Statistics.

1/ Based on January-August data.

2/ Iceland, Norway, and Switzerland. 
Table A49. Israel: Capital Account Transactions, 1992-97 1/

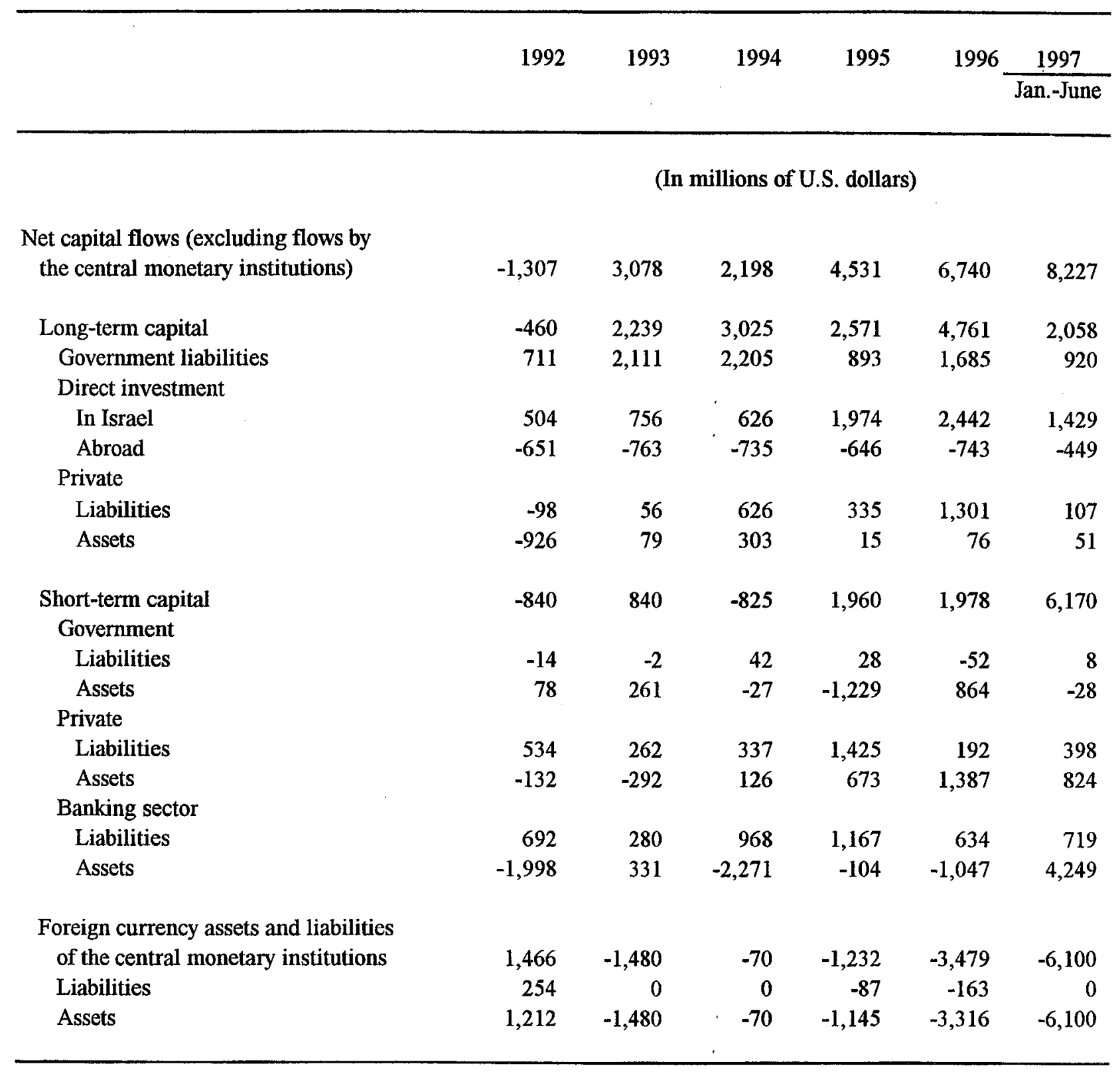

Source: Central Bureau of Statistics, Monthly Bulletin of Statistics.

1/ Excluding errors and omissions. Negative sign indicates an increase in assets or a decrease in liabilities. 
Table A50. Israel: Indicators of External Indebtedness, 1992-97

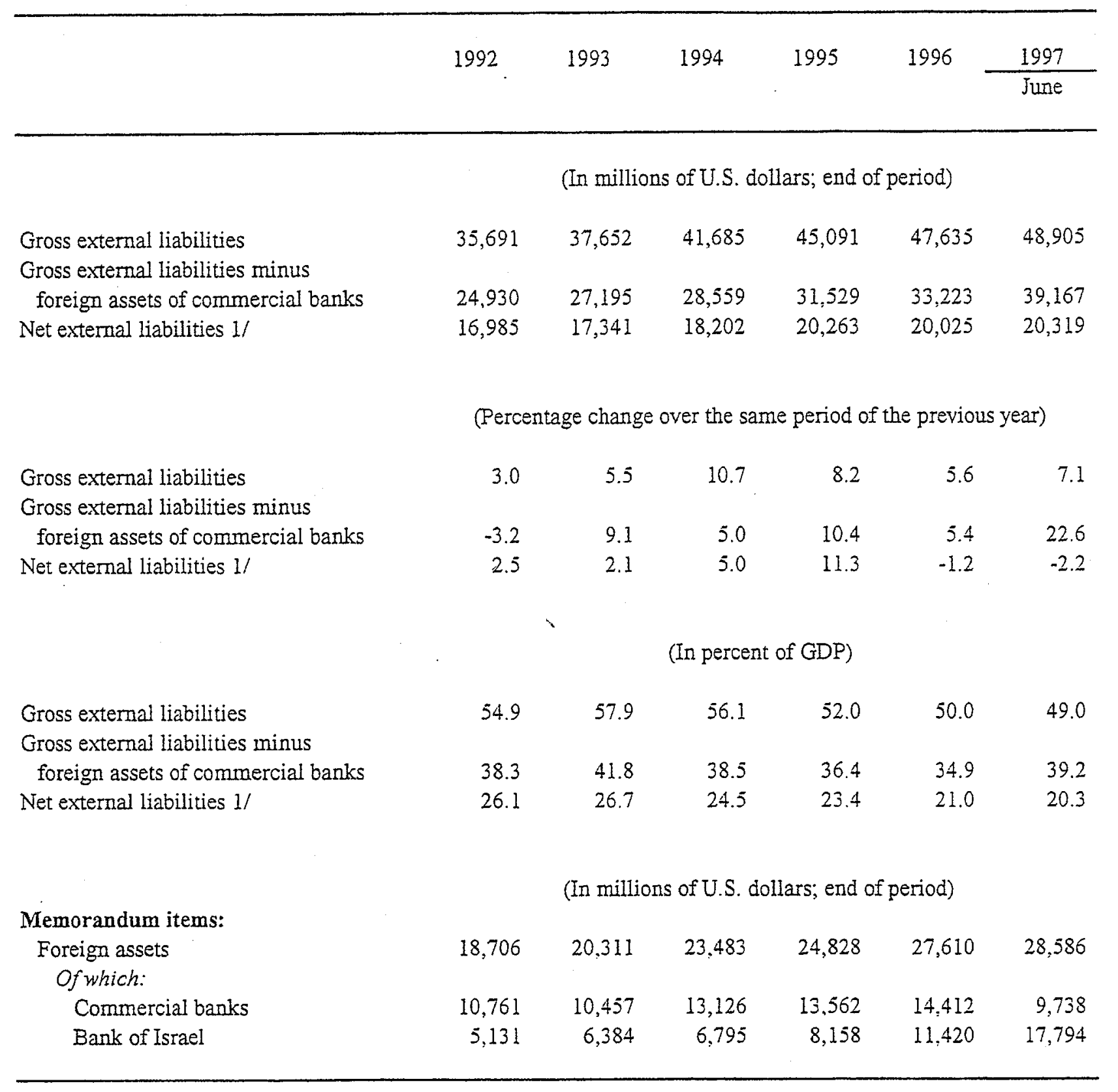

Sources: Central Bureau of Statistics, Monthly Bulletin of Sratistics; and data provided by the Bank of Israel.

1/ Net of foreign assets of commercial banks, Bank of Israel's reserves, holdings of other monetary institutions. and export credit. 
Table A51. Israel: Indicators of Debt Service, 1992-97

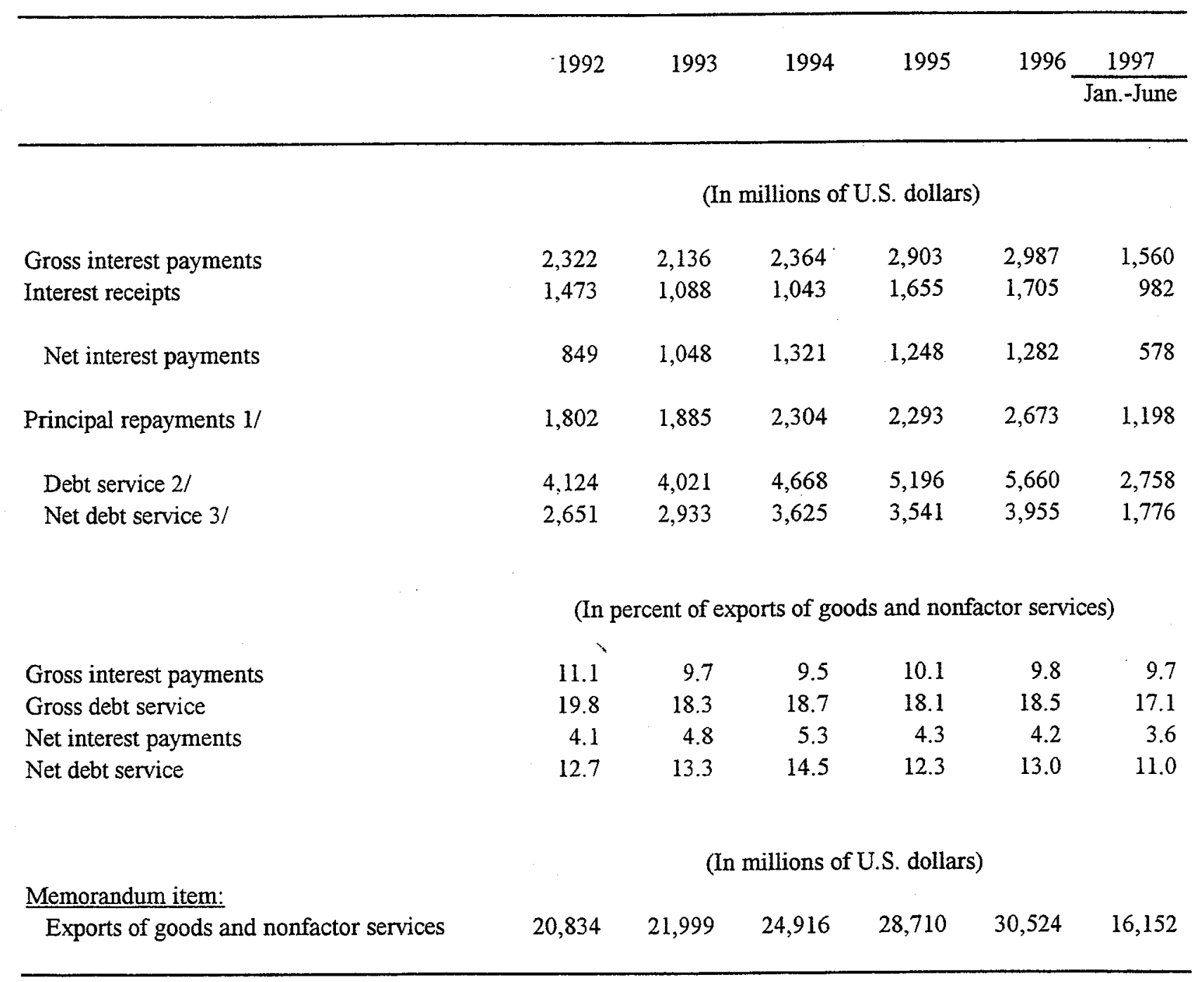

Source: Data provided by the Bank of Israel.

1/ Excludes short-term debt.

2/ Gross interest payments plus principal repayments.

3/ Net interest payments plus principal repayments. 
Table A52. Israel: Assets and Liabilities in Foreign Currency, 1992-97

\begin{tabular}{|c|c|c|c|c|c|c|}
\hline & 1992 & 1993 & 1994 & 1995 & 1996 & 1997 \\
\hline & & & & & & June \\
\hline & \multicolumn{6}{|c|}{ (In millions of U.S. dollars; end of period) } \\
\hline Gross liabilities & 35,691 & 37,652 & 41,686 & 45,091 & 47,635 & 48,906 \\
\hline Government & 18,379 & 20,340 & 22,742 & 23,793 & 25,303 & 25,943 \\
\hline Nonfinancial private sector & 4,965 & 4,747 & 5,082 & 6,046 & 6,784 & 7,007 \\
\hline Bank of Israel & 284 & 284 & 298 & 238 & 70 & 38 \\
\hline Banks & 12,063 & 12,281 & 13,564 & 15,014 & 15,478 & 15,918 \\
\hline Gross assets & 18,705 & 20,311 & 23,483 & 24,828 & 27,610 & 28,587 \\
\hline Bank of Israel reserves & 5,131 & 6,384 & 6,795 & 8,158 & 11,420 & 17,794 \\
\hline Other financial institutions & 534 & 669 & 542 & 530 & 371 & 449 \\
\hline Exporters' credit & 2,279 & 2,801 & 3,020 & 2,578 & 1,407 & 606 \\
\hline Banking system & 10,761 & 10,457 & 13,126 & 13,562 & 14,412 & 9,738 \\
\hline Net liabilities $\mathbf{1 /}$ & 16,986 & 17,341 & 18,203 & 20,263 & 20,025 & 20,319 \\
\hline Total current debt & 5,734 & 5,814 & 4,312 & 6,141 & 5,140 & 10,896 \\
\hline Banking system (net) & 1,562 & 1,822 & 437 & 1,451 & 1,067 & 6,300 \\
\hline Nonfinancial private sector & 2,387 & 2,124 & 1,813 & 2,419 & 1,890 & 1,987 \\
\hline Direct government debt & 0 & 0 & 0 & 9 & 10 & 0 \\
\hline $\begin{array}{l}\text { Medium- and long-term debt } \\
\text { (repayable within a year) }\end{array}$ & 1,785 & 1,868 & 2,062 & 2,262 & 2,173 & 2,609 \\
\hline Net current debt $2 /$ & $-2,210$ & $-4,040$ & $-6,045$ & $-5,125$ & $-8,058$ & $-7,953$ \\
\hline
\end{tabular}

Sources: Central Bureau of Statistics, Monthly Bulletin of Statistics; and data provided by the Bank of Israel.

1/ Gross liabilities minus gross assets.

2/ Total current debt minus Bank of Israel reserves, other financial institutions' reserves, and exporters' credit. 
Table A53. Israel: Official Gold and Convertible Foreign Exchange Reserves, 1992-97

\begin{tabular}{|c|c|c|c|c|c|}
\hline & Gold 1/ & SDRs & $\begin{array}{c}\text { Reserve } \\
\text { position } \\
\text { in the Fund }\end{array}$ & $\begin{array}{c}\text { Foreign } \\
\text { exchange } 2 /\end{array}$ & Total 3/ \\
\hline & \multicolumn{5}{|c|}{ (In millions of U.S. dollars; end of period) } \\
\hline 1992 & 0.4 & 0.3 & -- & $5,131.1$ & $5,131.5$ \\
\hline 1993 & 0.4 & 0.5 & -- & $6,383.7$ & $6,384.1$ \\
\hline \multicolumn{6}{|l|}{1994} \\
\hline $\mathrm{I}$ & 0.4 & 0.7 & -- & $6,841.0$ & $6,841.4$ \\
\hline$\amalg$ & 0.4 & 0.4 & - & $6,048.3$ & $6,048.7$ \\
\hline III & 0.4 & 1.3 & -- & $5,708.8$ & $5,709.2$ \\
\hline IV & 0.4 & 0.4 & -- & $6,794.3$ & $6,794.7$ \\
\hline \multicolumn{6}{|l|}{1995} \\
\hline I & 0.5 & 0.6 & - & $8,946.8$ & $8,947.3$ \\
\hline II & 0.5 & 1.8 & -- & $8,779.7$ & $8,780.2$ \\
\hline III & 0.5 & 34.2 & -- & $8,838.1$ & $8,838.6$ \\
\hline IV & 0.5 & 33.8 & -- & $8,157.3$ & $8,157.8$ \\
\hline \multicolumn{6}{|l|}{1996} \\
\hline I & 0.4 & 33.2 & -- & $9,696.9$ & $9,697.3$ \\
\hline II & 0.4 & 33.2 & -- & $8,886.7$ & $8,887.1$ \\
\hline III & 0.4 & 33.3 & - & $10,229.1$ & $10,229.5$ \\
\hline IV & 0.4 & 33.4 & -- & $11,419.4$ & $11,419.8$ \\
\hline \multicolumn{6}{|l|}{1997} \\
\hline I & 0.4 & 0.2 & -- & $15,335.6$ & $15,336.0$ \\
\hline II & 0.4 & 1.6 & -- & $17,793.5$ & $17,793.9$ \\
\hline III & 0.4 & 0.2 & -- & $18,946.7$ & $18,946.9$ \\
\hline
\end{tabular}

Sources: IMF, International Financial Statistics; and data provided by the Bank of Israel.

1/ National value.

2/ At the Bank of Israel.

3/ Gold plus foreign exchange. 

